UNIVERSIDADE DE SÃO PAULO

FACULDADE DE ECONOMIA, ADMINISTRAÇÃO E CONTABILIDADE DE RIBEIRÃO PRETO DEPARTAMENTO DE ADMINISTRAÇÃO

ANÁLISE DA FORMAÇÃO DE PREÇO DE PRODUTOS: UM ESTUDO MULTICASOS EM SUPERMERCADOS

PAULA BULAMAH SPINELLI

Orientador: Prof. Dr. Flávio Torres Urdan

RIBEIRÃO PRETO

2006 
Reitora da Universidade de São Paulo Profa. Dra. Suely Vilela

Diretor da Faculdade de Economia, Administração e Contabilidade de Ribeirão Preto Prof. Dr. Marcos Cortez Campomar

Chefe do Departamento de Administração Prof. Dr. Marcio Mattos Borges de Oliveira 
PAULA BULAMAH SPINELLI

\section{ANÁLISE DA FORMAÇÃO DE PREÇO DE PRODUTOS: UM ESTUDO MULTICASOS EM SUPERMERCADOS}

Dissertação apresentada ao Mestrado do Programa de Pós-Graduação em Administração de Organizações do Departamento de Administração da Faculdade de Economia, Administração e Contabilidade de Ribeirão Preto da Universidade de São Paulo.

Orientador: Prof. Dr. Flávio Torres Urdan.

\section{Ribeirão Preto}




\section{FICHA CATALOGRÁFICA}

Spinelli, Paula Bulamah

Análise da Formação de Preços de Produtos: Um Estudo Multicasos em Supermercados. Ribeirão Preto, 2006. $170 \mathrm{p}$.

Dissertação de Mestrado, apresentada à Faculdade de Economia, Administração e Contabilidade de Ribeirão Preto/USP Área de concentração: Marketing.

Orientador: Urdan, Flávio Torres.

1. Preços. 2. Produto. 3. Supermercado. 


\section{FOLHA DE APROVAÇÃO}

Paula Bulamah Spinelli

Análise da Formação de Preço de Produtos: Um Estudo Multicasos em Supermercados

Dissertação apresentada ao Mestrado do Programa de Pós-Graduação em Administração de Organizações do Departamento de Administração da Faculdade de Economia, Administração e Contabilidade de Ribeirão Preto da Universidade de São Paulo.

Área de Concentração: Marketing

Aprovada em:

Banca Examinadora

Prof. Dr.

Instituição:

Assinatura:

Prof. Dr.

Instituição: Assinatura:

Prof. Dr.

Instituição: Assinatura: 
Dedico este trabalho aos meus pais, Rosi e Luiz Spinelli e meu irmão Rui. Meus grandes exemplos.

Para meus queridos tios Carlos Eli e Maria Tereza Piccinato e as minhas "irmãs" Carla, Cinthia e Sabrina Piccinato que estiveram sempre aо meu lado. 


\section{AGRADECIMENTOS}

Ao Professor e Orientador Dr. Flávio Torres Urdan, a minha gratidão pela orientação valiosa, competência, confiança, amizade e, antes de tudo, por ter representado muito mais do que seu papel e ter me dado todo o apoio necessário nessa caminhada.

Ao Diretor da FEARP, Professor Dr. Marcos Cortez Campomar, pelas sugestões e discussões que ajudaram a aprimorar este trabalho e por de ter compartilhado um pouco do seu conhecimento comigo.

Aos professores Dr. Dirceu Tornavoi de Carvalho e Dr. Marcos Fava Neves, pelo apoio durante todo o meu período de aprendizado na pós graduação.

Aos professores Dr. Márcio Mattos Borges de Oliveira e Dra. Sônia, pela amizade, pela torcida e oportunidade de compartilhar, junto a toda turma de pós-graduação, os momentos de alegria.

Ao pessoal da Secretaria de Pós-Graduação da FEARP, em especial à Érika e ao Eduardo, por todo o apoio no curso.

Às “meninas da FUNDACE”, pela amizade, pela confiança e pelo apoio.

Aos profissionais que aceitaram e se dispuseram a participar da pesquisa, minha sincera gratidão.

As minhas amigas-irmãs de todas as horas, que me apoiaram nas decisões que tomei e que estão do meu lado há anos, Carla, Cínthia e Sabrina Piccinato e Juliana Freitas.

Aos amigos que fiz durante o mestrado, da primeira e segunda turma, aqui representados pela Flávia Ghisi e Janaína Giraldi, grandes companheiras de trabalhos, artigos, disciplinas e comemorações e a minha turma, pela convivência e apoio nos momentos críticos de avaliações, representada pelo meu amigo Marco Antonio Conejero, companheiro desde as entrevistas. 
"O homem nasceu para aprender, aprender tanto quanto a vida lhe permita." (João Guimarães Rosa) 


\section{RESUMO}

O presente trabalho analisa a importância da determinação de preços para a competitividade do varejo supermercadista. Após uma revisão da literatura sobre as diversas definições de preços e as formas de estabelecê-los, são analisadas as seis etapas propostas por especialistas de marketing para o apreçamento estratégico de produtos. Nessas seis etapas são discutidas a influência da demanda e a importância dos custos, os métodos de estabelecimento mais utilizados, descrevendo-se suas características e limitações, as técnicas de adequação à diversas situações, bem como a seleção do preço final. Os passos adotados pelos varejistas são também abordados, assim como outras variáveis que têm impacto na estratégia escolhida para se fixar os preços nos supermercados, além da demanda, dos custos e dos concorrentes. Por fim, as estratégias de apreçamento são estudadas empiricamente, por meio de entrevistas em profundidade com gerentes de três redes de varejo de grande porte que atuam no mercado nacional, onde é verificada a utilização das técnicas de apreçamento, como instrumento de auxílio na tomada de decisões relacionadas aos programas de preço da empresa. Em conclusão, verifica-se que à medida que os especialistas em varejo buscam mais bases científicas e confiáveis para auxiliar na tomada de decisões quanto à definição de políticas de preços, é essencial que possuam uma compreensão clara dos conceitos e das variáveis da que influenciam na determinação dos preços dos produtos que comercializam, assim como o conhecimento das diversas técnicas de apreçamento, além do mark-up.

Palavras-chave: preço, produto, supermercados 


\begin{abstract}
The present paper analyses the importance of pricing for the competitiveness of the retail sector (supermarkets). After a bibliographic survey on the several definitions concerning price and how it is determinate, six steps, proposed by marketing experts, to products strategic pricing are analyzed. In these steps, the demand influence, the costs importance and the most important pricing methods are discussed, describing their characteristics and limitations, the techniques to adequate it to different situations, as so as the final price selection. The steps that are adopted by supermarket retail are also outlined, thus as the variables that have some influence on its chosen pricing strategy. Demand and competitors costs are also analyzed. Finally, pricing strategies are empirically studied through multicases study on three large retail chains. In this part, the use by these companies of pricing methods as a tool to assist decision making related to the long-run pricing programs is verified. In conclusion, it is seen that, while retail specialists seek more scientific and reliable bases for aiding the decisions regarding the price strategies, it is essential that they posses a clear comprehension of the concepts and the variables that have influence on products price determination that are commercialized by themselves, as well as the technical skills to pricing, besides the mark-up method.
\end{abstract}

Key-words: price, product, supermarket retail. 


\section{LISTA DE FIGURAS}

F igura 1: Componentes do preço na concepção do marketing ..............................................22

Figura 2. Fatores determinantese influenciadores das definições te preços........................25

Figura 3. Procedimnento tradicional para determninar o preço de umr produto.........................34

Figura 4. Procedtimtento para determnimar o custo-alvo de untr prodtuto...................................34

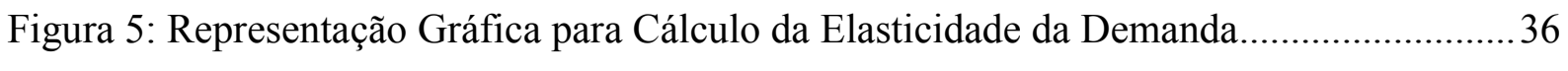

Figura 6: Curva de Demanda de um Vendedor Individual quando independentemente muda o

preço .................................................................................................................

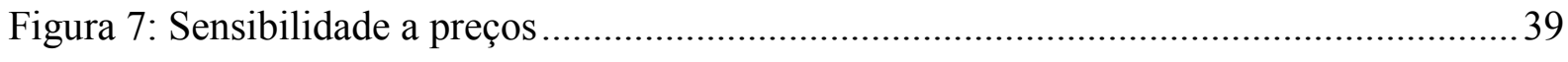

Figura 8. Economia de Eseala X Aprendizagem.........................................................46

Figura 9. O mrodeto dos 3 C's para a deternnirração de preços..........................................59

Figura 10. Elementos básicos da gestão de preços...................................................61

Figura 11. Modeto de satisfação e leatdade à loja...................................................76

Figura 12. Processo de seteção de toja....................................................................

Figura 13. Estabelecimrento de Preço no Varejo ..........................................................81 


\section{LISTA DE QUADROS E TABELAS}

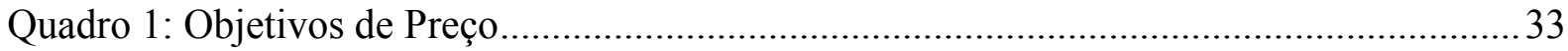

Puadro 2. Características determinantes de cada estrutura de Mercado ...............................54

Puatro 3. As decisões te preço em função da coneorrêneia ...........................................55

Quadro 4. Método de Detemminaçã̃o de Preços - características e limitações........................

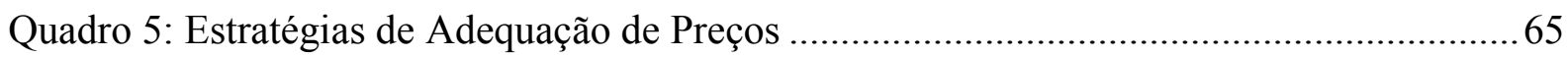

puadto 6. Unma ctassificação tos componentes da imagem de toja...................................74

puadro 7. Objetivos de Preçס Varejista ..................................................................... 82

Quadro 8. Métodos de Detemminação de Preços utilizados por Varejistas............................ of

puadro 9. Características que influenciam os níveis de preços no varejo ............................91

Tabeta 1 - As dez redes com maior faturamento do setor supermereadista brasiteiro..........123

Puadro 10. Dados sobre o setor supermercadista brasiteriro ...........................................124 


\section{SUMÁRIO}

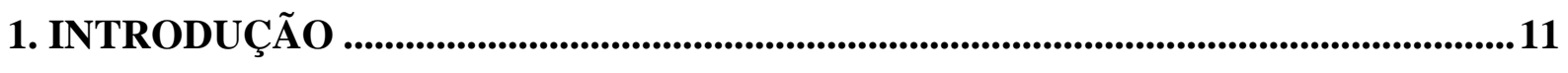

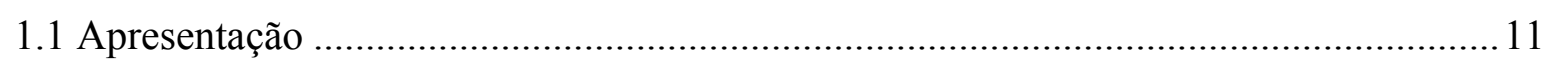

1.2 Problema Estudado na Dissertação.................................................................. 15

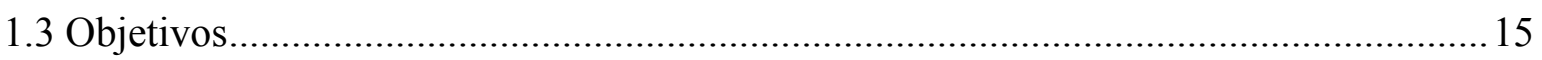

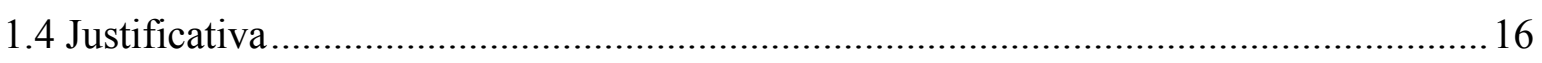

1.5 Organização do estudo......................................................................................... 18

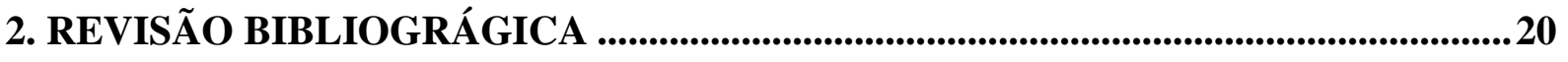

2.1 Definições e Estabelecimento de Preço .............................................................20

2.2 Seleção do Objetivo do Preço..................................................................................2 27

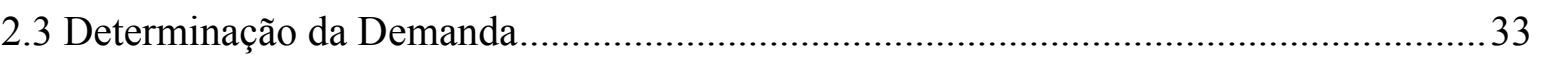

2.3.1 Determinação de Preços Baseado na Demanda (Cliente) ..................................4

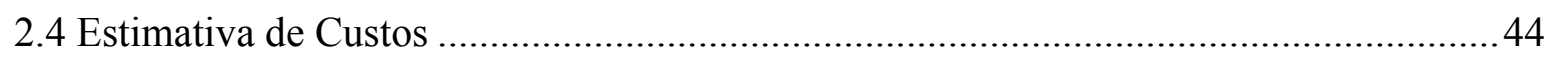

2.4.1 Determinação de Preços Baseados em Custos .................................................50

2.5 Análise dos Custos, Preços e Ofertas dos Concorrentes .......................................51

2.6 Seleção de um Método de Estabelecimento de Preço ...............................................58

2.7 Seleção do Preço Final ................................................................................. 62

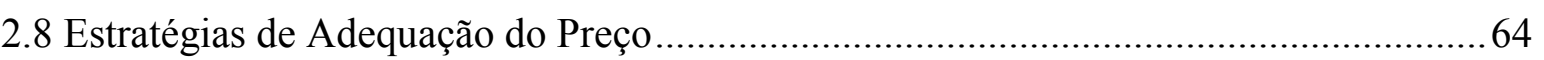

2.9 Gestão de Varejo Supermercadista............................................................................... 69

2.10 Estratégias de Apreçamento nos Supermercados .................................................... 79

2.11 Variáveis Qualitativas que Influenciam no Apreçamento dos Produtos no Varejo .....91

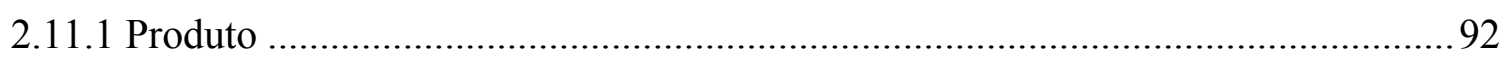

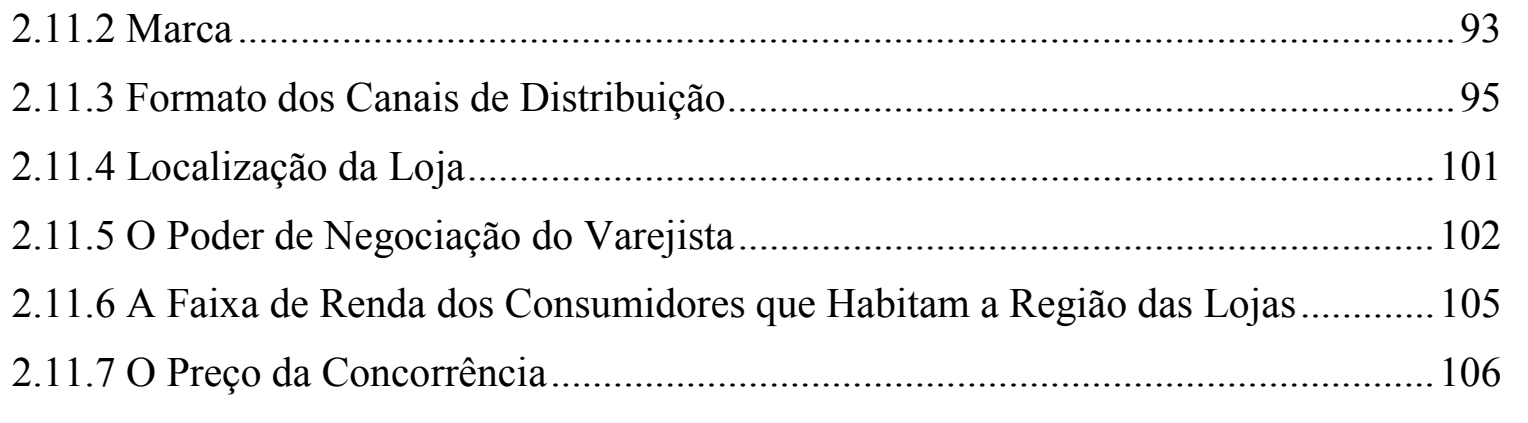


3.1 Escolha do Método da Pesquisa de Campo .............................................................. 109

3.1.1 O Tipo de Pesquisa ........................................................................................ 110

B.1.2 A Natureza da Pesquisa .......................................................................112

p.1.30 Oétodo da Pesquisa ............................................................................114

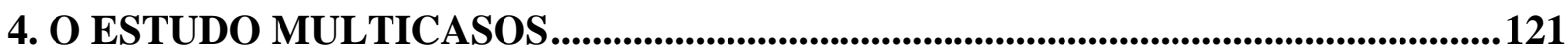

4.1 Os Supermercados no Brasil ........................................................................ 121

4.2 Caso 1 - Rede A ….................................................................................... 127

4.3 Caso 2 - Rede B ...................................................................................... 133

4.4 Caso 3 - Rede C ........................................................................................... 139

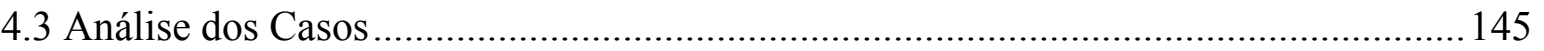

5. CONCLUSÕES.............................................................................................................................152

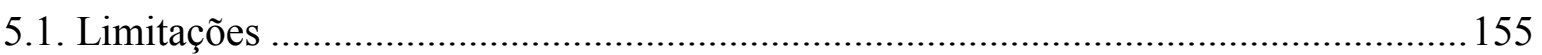

REFERÊNCIAS ......................................................................................................................157 


\section{INTRODUÇÃO}

\subsection{Apresentação}

Boone e Kurtz (1998) afirmam que filósofos antigos já reconheciam a importância do preço no sistema econômico, pois alguns documentos da época demonstram tentativas de determinar preços justos e moderados. Atualmente, o preço ainda exerce a função de regular a atividade econômica e o emprego de qualquer um dos quatro fatores de produção (terra, capital, recursos humanos e empreendedorismo) depende do preço que lhe é atribuído. Para uma empresa, os preços cobrados e as quantidades adquiridas de um produto, por seus clientes, representam a receita recebida, portanto, os preços, influenciam os lucros da companhia, bem como a utilização de seus fatores de produção (BOONE; KURTZ, 1998).

Além disso, o preço é um dos principais determinantes para a escolha dos produtos pelos compradores. É um dos elementos chave para alcançar o volume de vendas desejado e, por conseqüência, tem grande impacto nos lucros das empresas e tem o papel fundamental na percepção da qualidade do produto pelos consumidores.

Lopes, Reis e Abukawa (1996), afirmam que o preço é a variável do composto que pode ser mais facilmente comparada pelo consumidor no momento da compra. Os autores ainda citam que, em situações econômicas inflacionárias, recessivas ou ambas a determinação de preços de produtos pode se tornar uma tarefa bastante confusa. Mas por que o preço não apresentou o mesmo destaque que as demais variáveis do composto de marketing nos estudos acadêmicos e para os profissionais da área, como afirmam Nagle e Holden (2003)? 
Jain (2000), argumenta que a estabilidade econômica dos anos 60, no mundo, é que pode ser responsabilizada, particularmente, pelo baixo status atribuído à variável preço. Para o autor, estrategicamente, a função do apreçamento significava apenas atribuir um retorno adequado ao investimento realizado. Segundo o autor, nos anos 70, vários eventos foram responsáveis por uma reviravolta na tarefa de determinar os preços dos bens e serviços, entre eles o consumismo, o custo alto do dinheiro, o controle do comportamento dos preços praticados, falta de matérias-primas entre outros, todos tornaram o preço uma variável importante (JAIN, 2000; LAMBIN, 2000a).

Nagle e Holden (2003), afirmam que foi nos anos 80 que os profissionais de marketing enfrentaram grandes desafios. Empresas detentoras de marcas líderes viram a lealdade a suas marcas e seu poder junto aos distribuidores diminuir. As grandes empresas viram seus lucros caírem, enquanto as organizações menores atraíam seus clientes mais lucrativos. Então, líderes corporativos mostraram que era possível aumentar o fluxo de caixa e os lucros por meio dos preços mais altos, mesmo que essa estratégia resultasse em uma perda de participação de mercado (NAGLE; HOLDEN, 2003).

$\mathrm{O}$ acontecimento mostrou às empresas que a estratégia de determinação de preços deve ser cuidadosamente planejada e todas as técnicas de apreçamento devem ser dominadas pelos profissionais de marketing, principalmente no ambiente competitivo em que as companhias atualmente encontram-se inseridas.

A fixação de preços é considerada tão complexa que Kotler e Keller (2005), afirmam que as empresas lidam com o apreçamento de várias maneiras. Nas pequenas empresas eles são determinados pelos próprios dirigentes e nas grandes, são gerentes são gerentes de divisões e produtos os responsáveis pela tarefa. Em setores em que o preço é o fator-chave as organizações dispõem de um departamento específico para fixá-los ou auxiliar no 
apreçamento dos produtos. Este departamento está, geralmente, subordinado à diretoria de marketing, finanças ou à alta administração. Outros que exercem influência são os gerentes de vendas, de produção, gerentes financeiros e os contadores. Nagle e Holden (2003) atribuem essa mudança na estrutura como resultado do apreçamento estratégico, ou seja, as empresas estão, atualmente, administrando proativamente as condições do mercado.

Engle, Blackwell e Miniard (1995), afirmam ainda, que o preço é determinante para a escolha da loja supermercadista pelo cliente. A formação de preços de venda está, portanto, entre as mais importantes decisões da empresa. Apesar de parecer fácil, o apreçamento compreende um processo complexo por depender do grande número de variáveis quantitativas e qualitativas e estas nem sempre partem da decisão interna da organização, necessitando estarem inseridas no planejamento estratégico, capaz de refletir os objetivos da empresa (JAIN, 2000).

O varejo brasileiro, por exemplo, que é a unidade de análise do caso apresentado nesse estudo, enfatiza o aspecto preço como fator fundamental para a busca de um diferencial competitivo e para a conquista de clientes. $\mathrm{O}$ ambiente macro-econômico mundial nas últimas décadas, após sucessivas mudanças na economia, propiciou a chegada de novos competidores e novas tecnologias, fomentando de forma mais intensiva a disputa de mercado e motivando o setor industrial e o próprio varejo a investir e a procurar entender e se ajustar melhor às necessidades, desejos e expectativas dos consumidores (TOLEDO; PROENÇA; MELLO JR, 2003).

Parente (2000), defende que de todas as variáveis do composto de marketing, a decisão de preço é a que mais rapidamente afeta a competitividade, o volume de vendas, as margens e a lucratividade das empresas varejistas, pois podem ser mudadas rapidamente, da noite para o dia. 
A determinação do preço de venda dos produtos no varejo é uma decisão que deve ser tomada cuidadosamente e requer conhecimento das variáveis que podem afetar o bom desempenho dessa tarefa. Dessa forma, é pertinente descrever as estratégias das redes supermercadistas quanto ao apreçamento dos produtos que comercializam e identificar as variáveis que influenciam nessa estratégia.

No varejo supermercadista, as grandes redes demonstram, por comprarem grandes volumes de produtos, maior poder de barganha na negociação e, conseqüentemente, têm condições de vender ao consumidor produtos a um preço mais competitivo (GHISI, 2005). Mas só a vantagem na negociação pode garantir o sucesso do varejista em preços competitivos? Quais seriam as outras variáveis de marketing que poderiam influenciar no apreçamento dos produtos pelo varejo supermercadista?

O preço é fator-chave de posicionamento e, sendo assim, precisa ser definido em relação ao mercado-alvo, ao mix de sortimento de produtos e serviços e à concorrência (KOTLER; KELLER, 2005). McGoldrick (1990), ainda defende que no varejo, a determinação dos preços de venda dos produtos e serviços oferecidos ao consumidor final tende a ser um processo complexo devido à quantidade de itens comercializados e também da possibilidade de discriminação de preços entre regiões.

Morgenstein e Strogin (1992), afirmam que a conveniência tem um preço para o consumidor, o que indica a disposição para o pagamento de uma quantia mais elevada pelas facilidades e serviços oferecidos a esses clientes. Kotler e Armstrong (1998, p. 96), citam que "a empresa que realmente compreender como os consumidores respondem às diferentes características, preços e apelos de propaganda tem uma grande vantagem sobre seus concorrentes”. 
Nesse sentido, o presente trabalho analisou da formação de preços de produtos em supermercados e procurou identificar variáveis que influenciam a as decisões de apreçamento nesse tipo de organização. No final do estudo, têm-se recomendações focadas não apenas nos modelos de apreçamento mais adequados de acordo com a teoria, mas também como esses modelos são utilizados na prática e como as variáveis de marketing podem influenciar tais modelos. A seguir apresenta-se a justificativa da escolha do tema estudado.

\subsection{Problema Estudado na Dissertação}

No caso deste estudo, a pergunta que originou a pesquisa, fundamentada na revisão bibliográfica, foi assim definida:

Como são formados os preços de venda dos produtos no varejo supermercadista?

O objetivo geral e os objetivos específicos são apresentados a seguir.

\subsection{Objetivos}

O objetivo geral desta pesquisa é verificar como são formados os preços de venda dos produtos no varejo supermercadista. 
Os objetivos específicos para análise do setor são:

1. Verificar quais são os procedimentos de estabelecimento de preços dos produtos comercializados;

2. Verificar a importância da análise da demanda, dos custos e da concorrência na determinação dos preços desses produtos;

3. Verificar quais são os métodos de apreçamento existentes e suas adaptações;

4. Verificar quais são os principais objetivos de preço que os supermercados procuram atingir;

5. Verificar quais são as estratégias de apreçamento que os supermercados mais utilizam;

6. Verificar qual é a influência da demanda, dos custos e da concorrência no apreçamento dos produtos pelos supermercados;

7. Verificar quais são as outras variáveis que influenciam na determinação dos preços de venda dos produtos comercializados por eles;

\subsection{Justificativa}

A justificativa deste estudo está fundamentada em alguns dos aspectos defendidos por Barral (2003), considerados relevantes na decisão de fazer uma pesquisa científica: atualidade do tema, ou seja, a sua inserção no contexto atual, interesse do autor ou o vínculo do autor com o tema, a sua relevância que pode ser entendida como a importância social, política etc e a pertinência do tema, a sua contribuição. 
Nagle e Holden (2003) explicam que a literatura de marketing não evoluiu na mesma velocidade sobre questões que envolvem preço se comparada com as demais variáveis do composto de marketing. Historicamente, o pouco uso de métodos quantitativos em pesquisas da área de administração produziu um certo desequilíbrio no número de publicações envolvendo preços comparativamente aos demais componentes do mix de marketing. Os mesmo autores afirmam que os acadêmicos de marketing desprezavam a determinação de preços oferecendo pouca pesquisa na área e poucos cursos sobre o tema, assegurando aos seus alunos que, quando problemas decorrentes da definição de preços surgiam, todos poderiam ser solucionados indiretamente redobrando-se os esforços de diferenciação de produtos e serviços (NAGLE; HOLDEN, 2003).

Entretanto, a estabilidade da moeda brasileira nos últimos anos tem ampliado o foco das estratégias competitivas das organizações para o preço no país. Enquanto o processo inflacionário mantinha-se generalizado e em tendência crescente, a avaliação dos preços relativos pelos consumidores era um exercício pouco frutífero, ou seja, os consumidores não tinham memória de preços. Com a relativa estabilidade, este exercício começa a fazer mais sentido, tornando interessante avaliar até que ponto algumas variáveis como: preço do concorrente, conveniência e serviços, localização da loja, marca do produto, poder de barganha entre outras, influenciam a formação dos preços finais dos produtos pelos varejistas.

Além disso, o estudo sobre a formação de preços de produtos é uma questão importante para os profissionais de marketing por duas razões: primeiro, possibilita melhor compreensão das variáveis que podem influenciar a sua determinação, o que ajuda a entender porque alguns varejistas estão mais bem posicionados ou são mais competitivos no mercado do que outros e segundo, fornece informações importantes para conseguir a lealdade dos consumidores, já que, conforme citado anteriormente, o preço pode ser decisivo na escolha do consumidor por 
uma rede supermercadista. Estudo realizado por Vanhuele e Dreze (2002), demonstra que os consumidores têm um forte interesse em manter o conhecimento sobre os preços dos produtos que compram e Cao e Gruca (2001), afirmam que aqueles que são informados sobre os preços mais baixos vão direto à loja, sem qualquer custo de tempo ou de recurso financeiro.

O interesse pelo estudo está na oportunidade de participar de tal discussão em uma área importante para a economia atual e para acadêmicos e profissionais de marketing. Há também o momento competitivo e turbulento em que o varejo supermercadista brasileiro se encontra, o que torna a discussão oportuna.

Como contribuição o estudo pretende apresentar outras variáveis como influenciadoras na formação do preço e das estratégias de apreçamento, que podem auxiliar os varejistas na compreensão e avaliação de suas estratégias e de seus concorrentes e servir de base para futuras pesquisas sobre formação de preços.

\subsection{Organização do estudo}

O capítulo 1 descreveu apresentou o tema discutido, o problema de pesquisa investigado e definiu quais são os objetivos do estudo. O capítulo 2 reúne, apresenta e discute os referenciais teóricos necessários para a compreensão da formação de preços de produtos e aborda como a determinação de preços de venda acontece no varejo supermercadista, descrevendo também, quais variáveis de marketing que, possivelmente, influenciam nessa formação. 
Assim, no referencial teórico, apresentam-se as definições de preços, modelos de formação de preços, objetivos e estratégias de apreçamento e as variáveis utilizadas nessa formação. Discutem-se também os aspectos de gestão de varejo e as escolhas de apreçamento para o setor.

O capítulo 3 descreve o estudo empírico realizado com o objetivo de complementar a revisão bibliográfica realizada sobre preços. Neste capítulo, o método de pesquisa utilizado, o tipo de pesquisa, os procedimentos de coleta de dados, o instrumento de coleta e a discussão das análises necessárias para a realização dos casos foram apresentados.

No capítulo 4 encontram-se os resultados obtidos na pesquisa empírica e no capítulo 5 apresentam-se as conclusões, limitações do trabalho e sugestões de estudos futuros. 


\section{REVISÃO BIBLIOGRÁGICA}

\subsection{Definições e Estabelecimento de Preço}

Embora outras variáveis do composto de marketing sejam importantes, o preço permanece como um dos elementos fundamentais na determinação da participação de mercado e da lucratividade das empresas. As diferentes definições de preço existentes na literatura são, de alguma forma, bem parecidas, indicando que preço é o que você paga pelo que recebe.

As definições de preços se complementam e nenhuma é considerada errada, mas em algum momento os autores deixam de citar explicitamente características importantes da variável que não podem ser esquecidas no momento de sua apresentação. Por essa limitação, o presente tópico descreve várias citações de diferentes autores e discute tais definições, com o objetivo de chegar a uma síntese sobre a melhor forma de caracterizar a variável preço.

McCarthy (1982), define como preço o que é cobrado por algo, mesmo que este seja avaliado de forma incorreta. É a expressão monetária de algum bem ou serviço. Rossetti (2000), complementa considerando que essa expressão monetária resulta, segundo a tradição da teoria da microeconomia, da utilidade avaliada pelos que têm a necessidade e procuram satisfazê-la, além dos custos calculados pelos que produzem. Estes, então, buscam ressarci-los pela oferta.

Churchill Jr e Peter (2000), afirmam que preço é a quantidade de dinheiro, bens ou serviços que deve ser dada para adquirir a propriedade ou uso de um produto. Mas o preço é apenas 
parte do custo total que os clientes pagam numa troca, que inclui também o esforço mental e comportamental despendidos.

Lambim (2000) e Stanton, Walker, Etzel, (2001), definem o preço como uma relação que indica o montante necessário para adquirir uma dada quantidade de bem ou serviço e Sardinha (1995), diz que é o elemento quantitativo que resume de forma numérica as estratégias de marketing que a empresa tentou seguir. Nesta mesma linha de raciocínio, Monroe (1990, p.05), define o preço como uma equação:

Preço= quantidade de dinheiro ou produtos e serviços recebidos pelo vendedor quantidade de produtos e serviços recebidos pelo comprador

Czinkota (2001), afirma que o preço é uma troca, o que faz sentido, pois, em termos gerais, qualquer troca envolve preço, que nem sempre é monetário. Junto com o conceito de Churchill Jr e Peter (2000), estes podem ser considerados os mais completos, na medida que consideram também fatores não monetários. O preço é apenas uma parte do custo total que os consumidores pagam em uma troca, pois esta inclui também o esforço mental e comportamental despendidos, além de desempenhar dois papéis, ou seja, se a compra será efetuada e se ela será lucrativa (CHURCHILL JR. E PETER, 2000). Porém, a definição de preço que está mais coerente com o trabalho é a de Sardinha (1995), que consegue reforçar a dependência do preço às outras variáveis do composto de marketing.

Urdan e Urdan (2006), explicam que “o marketing tem uma concepção mais elaborada do preço, associada ao conceito de valor percebido (a soma dos benefícios sobre a soma dos custos), sob a ótica do cliente" (URDAN; URDAN, 2006 p. 184). Os autores afirmam que preço é tudo o que o consumidor percebe ter dado ou sacrificado para obter o produto. $\mathrm{O}$ 
preço tem dois componentes. O primeiro é o monetário, que é a concepção usual do consumidor, mas que vai além do preço pago pelo produto e acrescenta os custos de operação, manutenção e depreciação do bem. O segundo é o componente não monetário, que consiste nos custos de tempo, de energia e psicológico para adquirir e utilizar o item (figura 1).

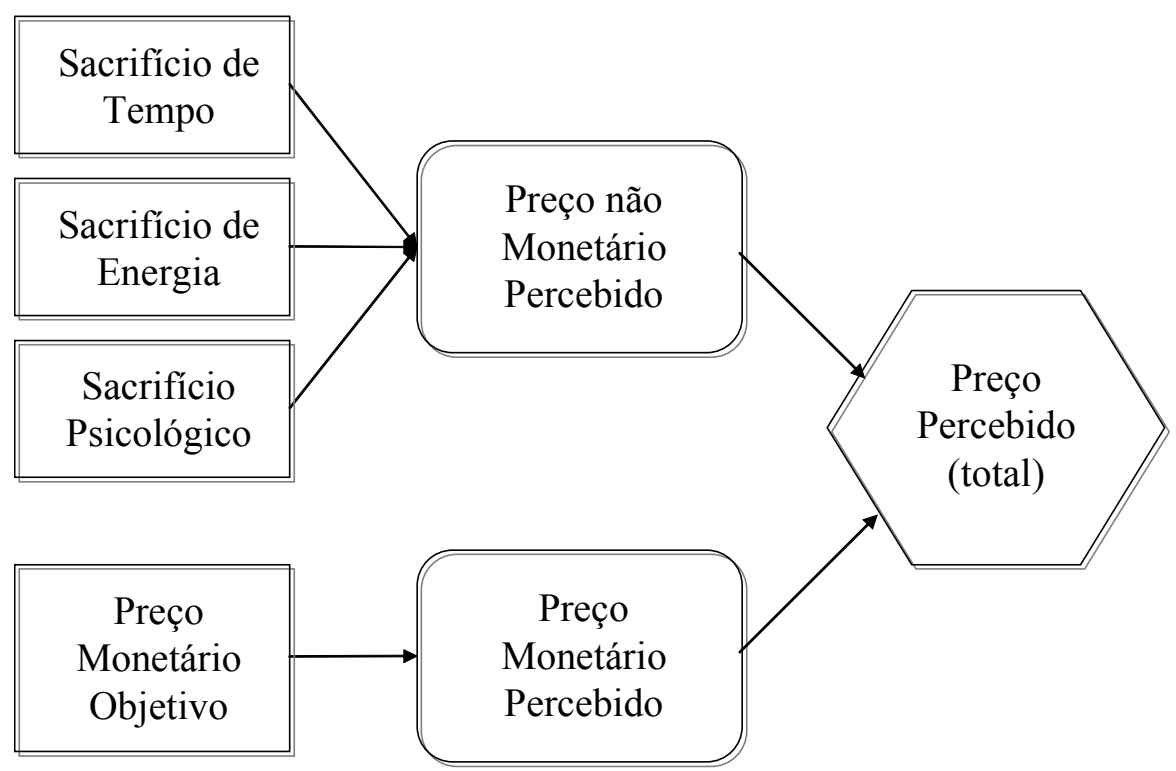

Fonte: Urdan e Urdan (2006).

\section{Figura 1: Componentes do preço na concepção do marketing}

Corey (1991), compara o estabelecimento de preços a um jogo de pôquer, no qual a empresa estabelece seu preço na ausência de informação completa, baseando-se em expectativas de retornos do mercado e retaliações da concorrência. Os movimentos são baseados nas forças de que a organização dispõe e nas estimativas das forças dos oponentes, como também em uma compreensão das suas ações típicas. Assim, qualquer negociação pode ser entendida como uma troca de algo de valor, geralmente dinheiro (preço), por satisfação (produto). A chave para determinar o preço de um produto está na compreensão do valor que os consumidores percebem. E esse valor resulta de suas percepções da satisfação total proporcionada pelo 
produto, do pacote total de utilidade. Ainda assim, o preço do produto é, muitas vezes, o fatorchave que conduz a uma troca.

Ao definir o preço, Ferrell (2000), argumenta que existem dois pontos que devem ser considerados: (i) que para uma empresa preço é a quantidade de dinheiro que ela está disposta a aceitar em troca de um produto e tal soma deve ser suficientemente alta para cobrir os custos e dar algum lucro, mas não tanto a ponto de impedir a venda de seu produto; (ii) para os consumidores, preço é a quantia que eles estão dispostos a desembolsar em troca de um produto. Portanto, é importante que exista um equilíbrio na construção deste, para que as duas partes se satisfaçam em sua transação comercial.

Na mesma linha de raciocínio, Rocha e Christensen (1999), afirmam que o preço define as condições básicas pelas quais o vendedor e o comprador estão dispostos a realizar a troca. Os autores ainda complementam que para a empresa, o preço pode ser visto como a compensação recebida pelos produtos e serviços que oferece ao mercado e, para o comprador, o preço expressa o que ele está disposto a dar para adquirir o que a empresa the oferece (bens ou serviços).

Lambin (2000a), também raciocina que a questão do preço tem dois aspectos importantes sob o ponto de vista das empresas a serem considerados: (i) o preço é um instrumento para analisar demanda e ao mesmo tempo, (ii) é um fator determinante da rentabilidade a longo prazo. Entretanto, a escolha por uma estratégia de apreçamento deve respeitar dois tipos de coerência: a interna e a externa. A interna diz respeito aos custos e a rentabilidade, essenciais para a sobrevivência da companhia e a externa, à força do mercado (poder de compra dos consumidores) e preço da concorrência. Além do mais, não se pode esquecer a coerência com as estratégias de produto e distribuição, a chamada consistência horizontal. 
Para o consumidor o preço é expressão monetária de um valor e tem papel central na troca. $\mathrm{O}$ comportamento de compra pode ser visto como um sistema de troca onde a procura pela satisfação e o sacrifício monetário compensam um ao outro. Esse comportamento é resultado de uma necessidade e a quantia que o consumidor está disposto a pagar pelo produto mede a intensidade dessa necessidade e a qualidade e satisfação que é esperada (LAMBIN, 2000a).

As decisões de preços são importantes, pois afetam o volume de vendas de uma empresa e quanto de recursos ela recebe. Mesmo com tal importância, muitas empresas não lidam bem com a determinação de preços. Segundo Kotler e Keller (2005), os erros mais comuns são: preços demasiadamente orientados para custos; os preços não sofrem revisão com suficiente freqüência para capturar mudanças praticadas pelo mercado, a determinação dos preços independe do restante do composto de marketing e a não variação de acordo com diferentes itens de produtos, segmentos de mercado e ocasiões de compra.

Lovelock (1996) e Kotler e Keller (2005), ainda referem-se ao preço como o único elemento do composto de marketing que produz receita, enquanto todos os outros produzem custos, sendo assim consideradas de mais difícil compressão. É visto também pelos autores como o mais flexível, pois pode ser alterado com rapidez, ao contrário das características de produtos, dos contratos com os canais de distribuição e as promoções planejadas. Essa flexibilidade dos preços praticados pelos concorrentes é um dos maiores problemas com o qual as empresas se deparam (PALMER, 2000).

O preço também informa ao mercado o posicionamento de valor pretendido por uma empresa, para seu produto ou marca (KOTLER; KELLER, 2005). Mazzon, Guagliardi, Fonseca (1983), afirmam que o preço é uma variável sensível em qualquer modelo em que é considerado, devido à característica de aumentar o lucro dos componentes do canal de distribuição e 
também por permitir ao consumidor aumentar suas possibilidade de consumo do produto bem como permitir o consumo de outros produtos.

Czinkota (2001), apresenta as principais variáveis envolvidas na definição de preços preocupações estratégicas, sensibilidade da demanda, custos e preocupações éticas e legais - e os fatores que influenciam na necessidade de ajuste, conforme a figura 2. Lambin (2000a), afirma que a noção de preço é ampla e vai além da simples coincidência dos fatos puramente objetivos e quantitativos. A quantidade de dinheiro pago mede de forma incompetente o sacrifício realizado e, da mesma maneira, a quantidade de bens adquiridos mede de forma imperfeita a satisfação.

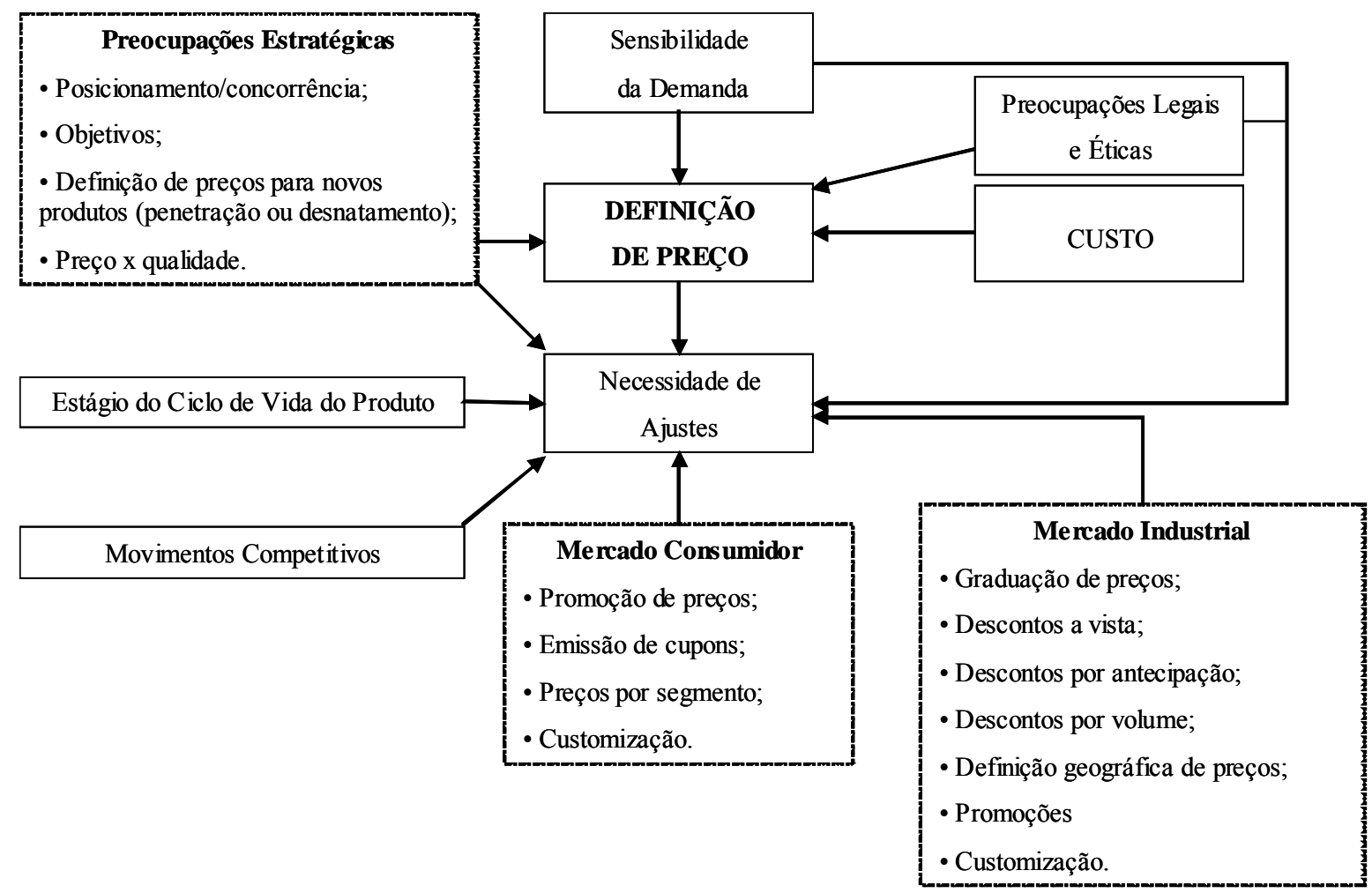

Fonte: Czinkota (2001).

Figura 2: Fatores determinantes e influenciadores das definições de preços. 
Lepsch (1996) considera a estratégia de formação de preços como um plano projetado e administrado de forma eficiente que considera a fixação de preços como uma função de custos, percepção do cliente e reações da concorrência.

Apesar de todas as estratégias existentes para as empresas determinarem o preço de seus produtos, quem irá decidir se esse é o preço correto ou não é o consumidor final. De nada adiantará uma companhia decidir sobre o apreçamento de seus bens ou serviços se o cliente não estiver disposto a pagar a quantia proposta. Portanto a política de formação de preço deve ser orientada para o consumidor, claro que de forma a cobrir os custos da empresa e gerar algum lucro, mas também analisando como os produtos atribuem benefícios, definindo um preço justo a esse valor percebido pelo usuário. Um consumidor racional somente irá adquirir um produto quando o valor percebido for maior que o valor pago para a aquisição deste item. O valor atribuído ao produto pode se caracterizar por diversas formas como a qualidade, o gosto, a ambientação, o status entre outros, sendo que esses atributos variam conforme os diferentes segmentos de consumidores e as diferentes situações de compra.

Entre tantas considerações e afirmações sobre preços, um ponto importante e comum entre todos os autores diz respeito à complexidade da sua determinação. Para que o apreçamento seja estabelecido de forma adequada, Kotler e Keller (2005), e Stanton, Waltker e Etzel, (2001), consideram que uma empresa deve seguir seis etapas: (1) seleção do objetivo da determinação de preços, (2) determinação da demanda, (3) estimativa de custos, (4) análise de custos, preços e oferta dos concorrentes, (5) seleção de um método de determinação de preços e (6) seleção do preço final. Cada uma dessas etapas será discutida neste trabalho. 


\subsection{Seleção do Objetivo do Preço}

Boone e Kurtz (1998), consideram que da mesma forma que o preço é um dos componentes do composto de marketing, os objetivos de determinação de preços também são um componente dos objetivos gerais da organização. Os autores explicam que os objetivos de marketing representam os resultados que os executivos esperam alcançar, que se baseiam nesses objetivos gerais. Os objetivos da empresa e da função de marketing provêem a base para determinar os objetivos da fixação de preços, usados para desenvolver e implementar os procedimentos e políticas de apreçamento mais específicas (BOONE; KURTZ, 1998).

Neves (2005), explica que a decisão de onde a empresa deseja posicionar sua oferta deverá ser o primeiro passo que a empresa adota, pois quanto mais claros os objetivos do plano de marketing, mais fácil será a determinação de preços. Deve-se decidir sobre os objetivos de preço antes de determinar o próprio preço. Entretanto, poucas empresas estabelecem um objetivo de preço. A importância de considerar esse passo fica clara quando as possíveis escolhas são apresentadas e a relevância e conseqüência que cada uma tem sobre o apreçamento de um produto.

São considerados cinco objetivos para a determinação de preço (KOTLER; KELLER, 2005; CZINKOTA, 2001): (1) sobrevivência; (2) maximização do lucro; (3) maximização do crescimento das vendas ou manutenção e/ou aumento da participação de mercado, (4) liderança na qualidade do produto e (5) maximização do aproveitamento do mercado ou desnatação. 
Os objetivos de maximização do lucro e do volume são mais comuns, mesmo entre autores que utilizam outras classificações. O objetivo de sobrevivência é considerado de curto prazo e geralmente praticado quando existe excesso de produção, concorrência intensa ou mudança nos desejos do consumidor. Quando optam por utilizar este objetivo, o preço estabelecido deve cobrir os custos variáveis e alguns dos custos fixos, caso contrário, a empresa pode ir à falência. No caso da liderança na qualidade do produto, as empresas têm seus produtos caracterizados por altos níveis de qualidade e valor percebidos, com preços altos, porém não a ponto de se tornarem quase inacessíveis aos consumidores. São os produtos de preçopremium.

A estratégia de preço-premium é aplicada para diferentes versões de um mesmo produto, uma superior e outra básica ou padrão. Os compradores potenciais do modelo padrão são muito sensíveis a preços, ao contrário dos compradores da versão superior do item. Uma variação do preço-premium é o preço de imagem. As duas estratégias têm o mesmo objetivo: sinalizar para os compradores desinformados a alta qualidade do produto e utilizar o lucro realizado com a versão superior para subsidiar o preço da versão básica ou padrão do produto (LAMBIN, 2000a). A característica que difere uma estratégia da outra é que, no segundo caso, não existe uma diferença real entre os produtos ou marcas, apenas considera-se a imagem passada e o posicionamento.

$\mathrm{Na}$ desnatação do mercado, os preços começam altos e se reduzem, gradualmente, com o tempo. É um objetivo praticado, geralmente, por empresas que lançam tecnologias novas e faz sentido apenas sob as seguintes condições: (i) um número suficiente de compradores tem uma demanda corrente alta; (ii) o custo unitário de produzir uma quantidade pequena não é alto suficiente para anular a vantagem de cobrar o que o mercado tem condições de pagar; (iii) o 
preço alto inicial não atrai mais concorrentes para o mercado e (iv) o preço elevado comunica a imagem de um produto de qualidade superior (KOTLER; KELLER, 2005).

Em outras palavras, Lambin (2000a) descreve a desnatação como objetivo atingir alta receita em vendas, oferecendo produtos com qualidades peculiares (reais ou percebidos) a preços muito altos, para alguns compradores ou segmentos específicos que estão preparados e dispostos a pagar por essa distinção. O objetivo aqui é alcançar o mais alto turnover possível com preço alto, em vez de volume alto (LAMBIN, 2000a). O autor considera esta a estratégia totalmente oposta à maximização de volume.

Outros autores preferem agrupar os objetivos de formas diferentes. Para Jain (2000), eles podem ser orientados para o lucro e para o volume e Lambin (2000a), afirma que alguns objetivos podem ser também orientados para a concorrência. Boone e Kutz (1998), consideram quatro os principais objetivos de apreçamento: (1) objetivos de lucratividade; (2) objetivos de volume; (3) objetivos concorrenciais e (4) objetivos de prestígio.

Embora as classificações variem de um autor para outro, percebe-se nos agrupamentos que os objetivos de lucratividade e os objetivos de volume são comuns a todos os autores citados. Os objetivos concorrencias são equivalentes apenas entre Lambin (2000a) e Boone e Kutz (1998). O único grupo exclusivamente idealizado por Boone e Kutz (1998) é denominado objetivos de prestígio. Serão discutidos primeiramente os objetivos comuns a todos, em seqüência os objetivos orientados para a concorrência e, finalmente, a quarta proposta de agrupamento de Boone e Kutz (1998).

Jain (2000), considera que quando orientado para o lucro, o objetivo pode ser definido tanto em termos da porcentagem de lucro desejada (maximização dos lucros), quanto do retorno almejado sobre o investimento. Lambin (2000a), cita a maximização do lucro como um 
modelo apresentado pelos economistas. Para o autor, o modelo é difícil de ser aplicado na prática, pois não apenas assume o conhecimento preciso sobre as funções de custo e demanda de cada produto, como também assume a estabilidade que é raramente aproveitada pelos fatores ambientais e competitivos.

Boone e Kutz (1998), afirmam que os economistas identificam a maximização dos lucros como o ponto no qual uma adição à receita total é equilibrada exatamente por um aumento no custo total e o problema está em saber como atingir esse equilíbrio. Para eles, a teoria econômica se baseia em pressupostos, sendo um deles o de que todas as empresas terão um comportamento racional, que resultará em um esforço para maximizar ganhos e minimizar perdas. Nicol (1985), considera que as empresas não podem ter um único objetivo, o da maximização do lucro, contudo, ele é um importante objetivo de uma empresa genérica.

O objetivo de retorno-alvo (ROI) é difundido (LAMBIN, 2000a). Na prática, calcula-se o preço-alvo, que é aquele o qual, para um nível de atividade, assegura um retorno justo sobre o capital investido. Para o autor, essa teoria, muito utilizada pelas empresas, tem o mérito da simplicidade, mas é incorreta, pois ignora o fato de que é o nível do preço que determina o nível da demanda. Boone e Kutz (1998), consideram que os objetivos de retorno-alvo oferecem uma série de vantagens ao profissional de marketing, servindo como um meio de avaliar desempenho. Além disso, são projetados para gerar um lucro "justo" de acordo com o julgamento dos gerentes, acionistas e público em geral (BOONE; KURTZ, 1998).

Por outro lado, Jain (2000), argumenta que o objetivo mais utilizado pelas grandes empresas é o preço voltado para volume. Boone e Kutz (1998), consideram que as empresas, nesta ocasião, estabelecem um nível mínimo aceitável de lucro e então procuram maximizar as vendas (sujeitas a esta restrição de lucro), acreditando que, no quadro de concorrência de longo prazo, um grande volume de vendas é mais importante do que lucros elevados logo de 
início. Assim, as empresas continuam a expandir suas vendas até o ponto em que os lucros totais não caiam abaixo dos retornos mínimos obtidos como aceitáveis pela companhia.

Os objetivos de volume também podem ser estabelecidos como a participação de mercado que a companhia gostaria de atingir, que pode começar como sendo a taxa de crescimento de vendas desejada, ou simplesmente assegurar um crescimento de vendas suficiente para a empresa (LAMBIN, 2000a). Para Lambin (2000a), maximizar a participação de mercado implica em adotar um preço de penetração, que é uma quantia relativamente baixa, menor do que o preço da concorrência, para aumentar o volume de vendas e, conseqüentemente, o market-share o mais rápido possível. Boone e Kutz (1998 p. 467), definem como "a meta estabelecida para controlar uma parcela do mercado, com uma determinada mercadoria ou serviço". Esta meta pode ser tanto a manutenção da atual participação, quanto o aumento dessa "fatia do mercado" em alguns pontos percentuais.

Lambin (2000a), afirma que além das orientações para o lucro e para o volume, a companhia tem um terceiro objetivo, desta vez orientado para a competição. Esta visão também é compartilhada por Boone e Kutz (1998). Neste caso os preços devem estar alinhados com os concorrentes ou objetivar s estabilidade. Para o autor, em indústrias lideradas por uma empresa, o objetivo é criar um relacionamento estável entre produtos concorrentes, para evitar flutuações de preços que podem abalar a confiança do consumidor. O objetivo de se alinhar aos preços das empresas concorrentes mostra que a companhia está consciente da sua incapacidade de exercer qualquer influência no mercado, especialmente quando existe uma empresa líder e os produtos são padronizados, como um oligopólio indiferenciado. Neste caso, a empresa prefere concentrar seus esforços outros aspectos que não seja o preço (LAMBIN, 2000a). Uma vez alcançada a posição de dominante, o objetivo muda para uma 
taxa de retorno suficiente ou satisfatória. Esta é uma estratégia freqüentemente utilizada por empresas com um volume alto de produção acumulada e que espera reduzir custos.

Os objetivos de prestígio compõe a última categoria de apreçamento não relacionada à lucratividade e ao volume. Um objetivo de prestígio envolve a determinação de um preço relativamente alto, para desenvolver e manter uma imagem de qualidade e exclusividade, direcionado para consumidores não sensíveis a preços e sensíveis a questão de status (BOONE; KURTZ, 1998). A utilização do objetivo de preço por prestígio reflete a ênfase dada pelo profissional de marketing muito mais à imagem do produto do que ao custo dos seus ingredientes ou materiais de fabricação. O quadro 1 apresenta um resumo geral dos objetivos de preços e suas características.

Definido o objetivo de preço a empresa precisa compreender as relações entre a fixação de preços e a curva de demanda. O preço é um fator essencial como determinante da demanda. Os quatro fatores considerados pelos economistas na determinação da demanda são: preço do produto, preço dos substitutos, renda dos consumidores e suas preferências. Caso os outros três fatores permaneçam constantes, quanto mais alto for o preço, menor será a demanda. $\mathrm{O}$ próximo tópico discute as relações entre a demanda e o preço de produtos e suas implicações. 


\section{Quadro 1: Objetivos de Preço}

\begin{tabular}{|l|l|}
\hline \multicolumn{1}{|c|}{ Objetivo } & \multicolumn{1}{|c|}{ Característica } \\
\hline Sobrevivência & $\begin{array}{l}\text { Objetivo de curto prazo geralmente praticado quando existe excesso de } \\
\text { produção, concorrência intensa ou mudança nos desejos do consumidor. }\end{array}$ \\
\hline $\begin{array}{l}\text { Maximização do } \\
\text { Lucro }\end{array}$ & $\begin{array}{l}\text { Quando são estimados a demanda e os custos com preços alternativos e } \\
\text { escolha do nível que maximiza o lucro, e se estabelece um nível específico } \\
\text { de lucro como objetivo. }\end{array}$ \\
\hline $\begin{array}{l}\text { Maximização do } \\
\text { Volume }\end{array}$ & $\begin{array}{l}\text { Meta estabelecida para controlar uma parcela do mercado, com uma } \\
\text { mercadoria ou serviço. Pode ser para manter ou aumentar a "fatia". }\end{array}$ \\
\hline $\begin{array}{l}\text { Liderança na } \\
\text { Qualidade do Produto }\end{array}$ & $\begin{array}{l}\text { Produtos com alta qualidade, preço relativamente alto, mas benefício } \\
\text { percebido. Gera lealdade e o preço não dificulta o acesso, apenas traduz a } \\
\text { qualidade. }\end{array}$ \\
\hline Desnatamento & $\begin{array}{l}\text { Quando há estimativa do preço mais alto que se pode cobrar, dados os } \\
\text { benefícios comparativos em relação aos substitutos disponíveis, para uma } \\
\text { posterior redução do preço e assim conquistar o segmento imediatamente } \\
\text { inferior. }\end{array}$ \\
\hline Concorrenciais & $\begin{array}{l}\text { Preços equivalentes aos da concorrência e diferenciação por meio dos } \\
\text { outros componentes do mix de marketing. }\end{array}$ \\
\hline Prestígio & $\begin{array}{l}\text { Preço alto para consumidores sensíveis à status; ênfase na imagem do } \\
\text { produto e não ao custo dos seus ingredientes ou materiais de fabricação. }\end{array}$ \\
\hline
\end{tabular}

Fonte: Elaborado pela autora a partir de Boone e Kutz (1998); Czinkota, (2001); Kotler e Keller (2005); Lambin (2000a); Lambin (2000b) e Stanton; Waltker e Etzel, (2001).

\subsection{Determinação da Demanda}

O apreçamento estratégico de um produto não deve considerar apenas os custos, é importante identificar o nível de demanda ao longo do tempo. Preços baseados apenas nas necessidades financeiras da empresa são considerados inapropriados segundo Lambin (2000a). Em uma economia de mercado, é o comprador quem decide que produto será vendido. Conseqüentemente, em uma organização bem sucedida, um apreçamento efetivo começa com 
o preço mais próximo de ser aceito pelo mercado, que por sua vez determina o custo-alvo da empresa (LAMBIN, 2000a).

O custo-alvo é um conceito que foi desenvolvido em meados da década de 90 . Ao contrário da prática tradicionalmente utilizada (primeiro desenvolve-se o produto e o custo é a base para a determinação do preço: figura 3), o custo-alvo leva em consideração, primeiramente, a necessidade do consumidor, descoberta por meio de pesquisas de mercado; em seguida o valor que ele dá ao produto; o preço do mercado e o quanto o cliente pagaria para adquiri-lo, a partir desse ponto, avaliar os custos para o desenvolvimento do bem, compará-lo com o preço e desenvolver, efetivamente, o produto (figura 4).

A determinação da demanda em alguns casos é clara, porém em outros, os padrões só são revelados quando devidamente estudados e mapeados. Cada preço praticado pela empresa resultará em um diferente nível de demanda e conseqüentemente causará diferentes impactos nos objetivos de marketing de uma empresa.

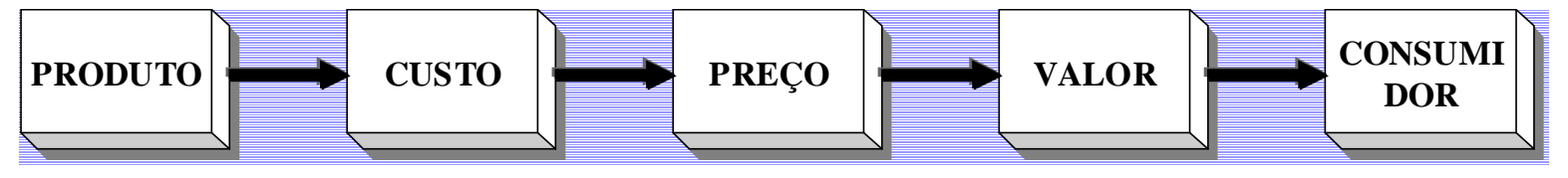

Fonte: Elaborado pela autora a partir de Lambin (2000a)

Figura 3: Procedimento tradicional para determinar o preço de um produto.

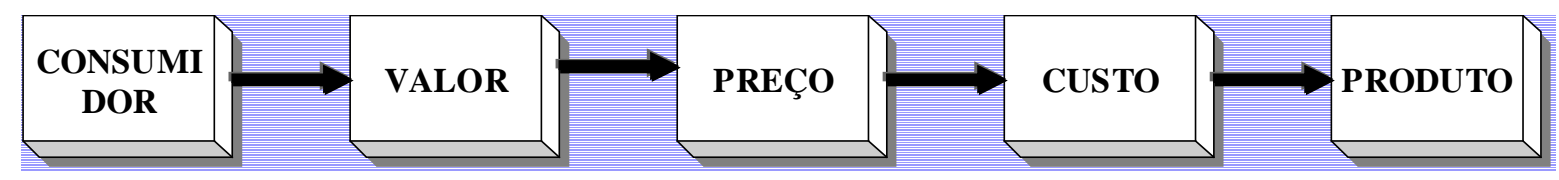

Fonte: Elaborado pela autora a partir de Lambin (2000a)

Figura 4: Procedimento para determinar o custo-alvo de um produto. 
Lambin (2000a), considera a noção de elasticidade um importante conceito na análise da demanda, pois mede, diretamente, a sensibilidade a preço do consumidor. Churchill Jr e Peter (2003), definem elasticidade-preço como "a medida da sensibilidade da demanda à mudanças nos preços".

Simonsen (1973), explica que o economista Marshall, primeiro a encontrar uma forma prática de expressar o conceito da elasticidade da demanda, a definiu como o aumento percentual da quantidade procurada, quando o preço abaixa $1 \%$. Se a quantidade procurada de um item aumentar $2 \%$, porque seu preço caiu em $1 \%$, significa que o seu coeficiente de elasticidade é igual a 2. Deve considerar, porém, que o conceito de elasticidade refere-se a um ponto da curva de demanda e não da curva completa.

Para determinar a elasticidade em $\mathrm{P}$, traça-se uma tangente à curva por esse ponto, a qual intercepta os eixos do gráfico, respectivamente, nos pontos $\mathrm{M}$ e $\mathrm{N}$ (figura 5). O coeficiente da elasticidade é representado pela fórmula:

$$
\mathrm{E}=\frac{M P}{P N}
$$

Kotler e Armstrong (1998), consideram que a elasticidade da demanda pode ser medida pela relação entre a variação da quantidade vendida e a variação do preço. Quanto mais alto o resultado, maior é a relação da demanda e de preço e Lambin (2000a), descreve a fórmula como a porcentagem de variação de unidades vendidas, sobre a porcentagem de variação do preço. 


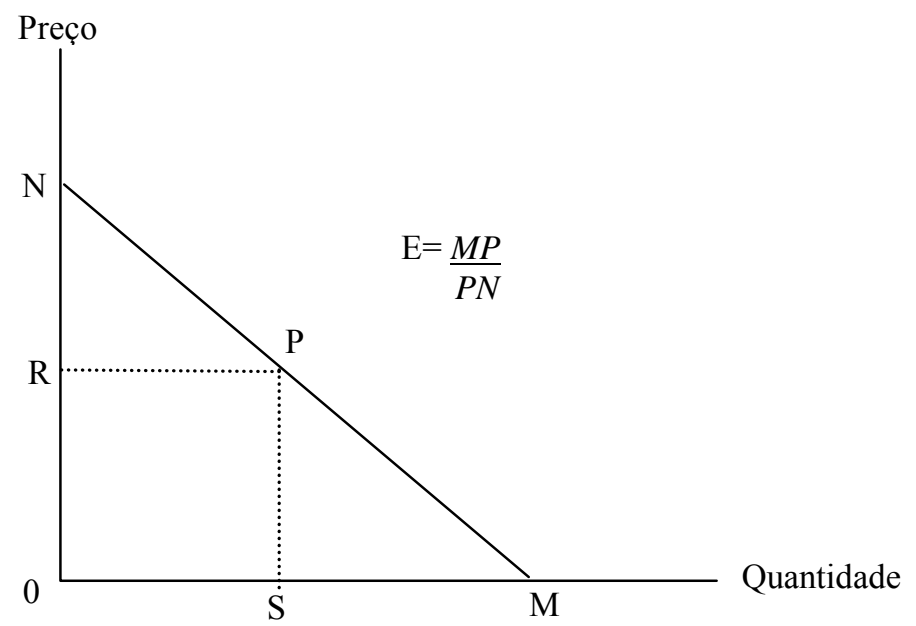

Fonte: Simonsen, 1973.

Figura 5: Representação Gráfica para Cálculo da Elasticidade da Demanda

Besanko, Dranove e Shanley (2000) afirmam que quando um vendedor reduz o seu preço, independentemente do setor, de P0 para P1 (com todos os seus concorrentes segurando o preço em P0), ele move, na curva de demanda, de DD para dd e suas vendas aumentam para Q11. Parte do crescimento (Q1 - Q0) vem de seus consumidores leais e a outra parte (Q11 Q1) vem dos consumidores de outras empresas (BESANKO; DRANOVE; SHANLEY, 2000). A figura 6 representa a curva de demanda quando uma empresa muda seu preço no mercado.

A curva de demanda pode ser elástica ou inelástica. Quando o coeficiente de demanda de um produto ou serviço é inferior a $1\left(\sum<1\right)$, a demanda é considerada inelástica e quando é maior do que $1\left(\sum<1\right)$, a demanda é considerada elástica. No que diz respeito à política de preços, a determinação precisa dos seus custos será mais importante quanto maior for o coeficiente de elasticidade. Quando a demanda é inelástica ou pouco elástica, o volume de vendas não é afetado pelas mudanças de preço, assim a empresa pode transferir os aumentos de custos ao consumidor sem maiores perdas. Porém, quando a demanda é altamente elástica, deve-se realizar uma análise de custos que permitirá a projeção de prováveis margens de 
lucro, em diferentes níveis de venda, com base nas relações entre preço e quantidade em cada nível (SIMONSEN, 1973; KOTLER; KELLER, 2005; BESANKO; DRANOVE; SHANLEY, 2000; NICOL, 1983; MCCARTHY; PERREAULT, 1997; MCGUIGAN,1999).

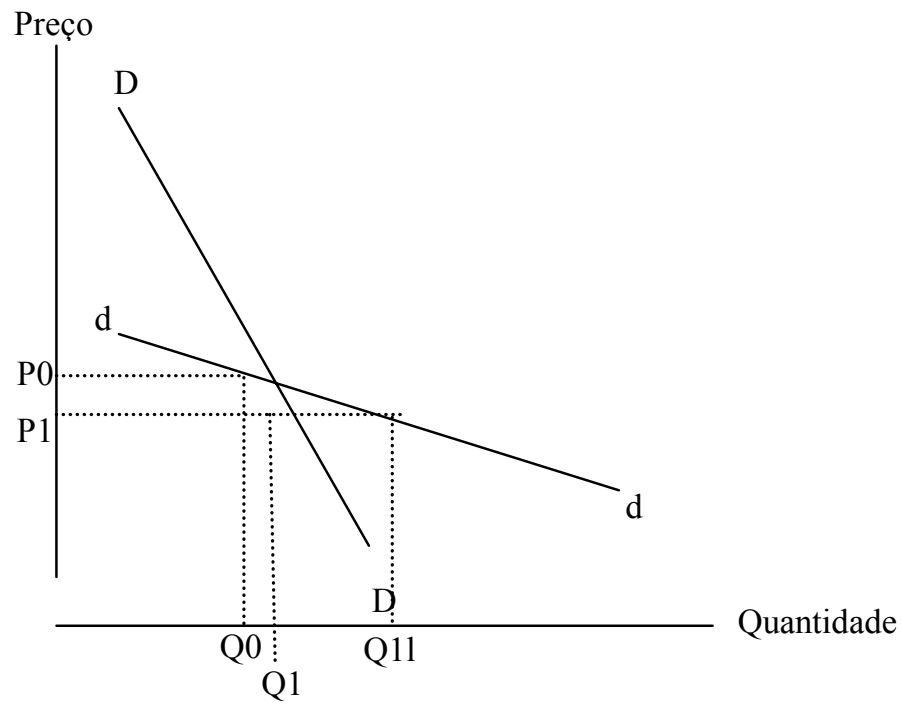

Fonte: Adaptado de Besanko, Dranove e Shanley (2000).

Figura 6: Curva de Demanda de um Vendedor Individual quando independentemente muda o preço.

A demanda elástica ocorre quando a redução de preços faz com que aumente a quantidade vendida o suficiente para compensar a receita e os resultados (MCCARTHY; PERREAULT, 1997). No setor alimentício, a demanda é considerada inelástica (a redução de preços não faz com que ocorra um acréscimo substancial no volume de vendas), porém quando analisada por loja ou rede varejista é considerada elástica, pois os consumidores passam a escolher o estabelecimento que tiver melhores níveis de preços.

"A curva da demanda mostra o volume provável de compra do mercado ante alternativas de preços” (KOTLER; KELLER, 2005 p. 435). A curva resume as reações de consumidores com 
diferentes sensibilidades a preço, portanto, o primeiro passo para determinar a demanda é compreender os fatores que afetam a sensibilidade. Kotler e Keller (2005), afirmam que os compradores são menos sensíveis a preços de produtos comprados com pouca freqüência ou que inspiram prestígio. Os consumidores que apresentam pouca sensibilidade são os preferidos das empresas. Nagle e Holden (2003), Kotler e Keller (2005) e Lambin (2000a), indicam nove fatores relacionados à menor sensibilidade a preços:

1. O produto é exclusivo - valor único.

2. Os compradores têm menos consciência da existência de substitutos.

3. Os compradores não conseguem comparar facilmente a qualidade de substitutos.

4. A despesa é uma pequena parte do orçamento familiar.

5. O benefício final do produto é grande, ou seja, a despesa é pequena em relação ao custo total do produto final;

6. O custo do produto é compartilhado com terceiros.

7. O produto é utilizado em conjunto com bens comprados anteriormente.

8. O produto apresenta mais qualidade, prestígio ou exclusividade: Preço-Qualidade.

9. Os compradores não podem estocar o produto.

As empresas precisam entender a sensibilidade a preço de seus clientes atuais e potenciais, bem como as análises comparativas que as pessoas estão dispostas a realizar para avaliar o preço diante das especificações dos produtos (figura 7). Lambin (2000a), considera todo comprador sensível a preço, porém essa sensibilidade pode variar tremendamente de uma situação para outra, como mostram os fatores citados pelos estudiosos da área. Essa variação ocorre de acordo com a importância da satisfação que o produto proporciona, ou do sacrifício necessário para adquirir o bem. Ter somente consumidores sensíveis como alvo, pode significar que a empresa está deixando de ganhar dinheiro (KOTLER; KELLER, 2005). 


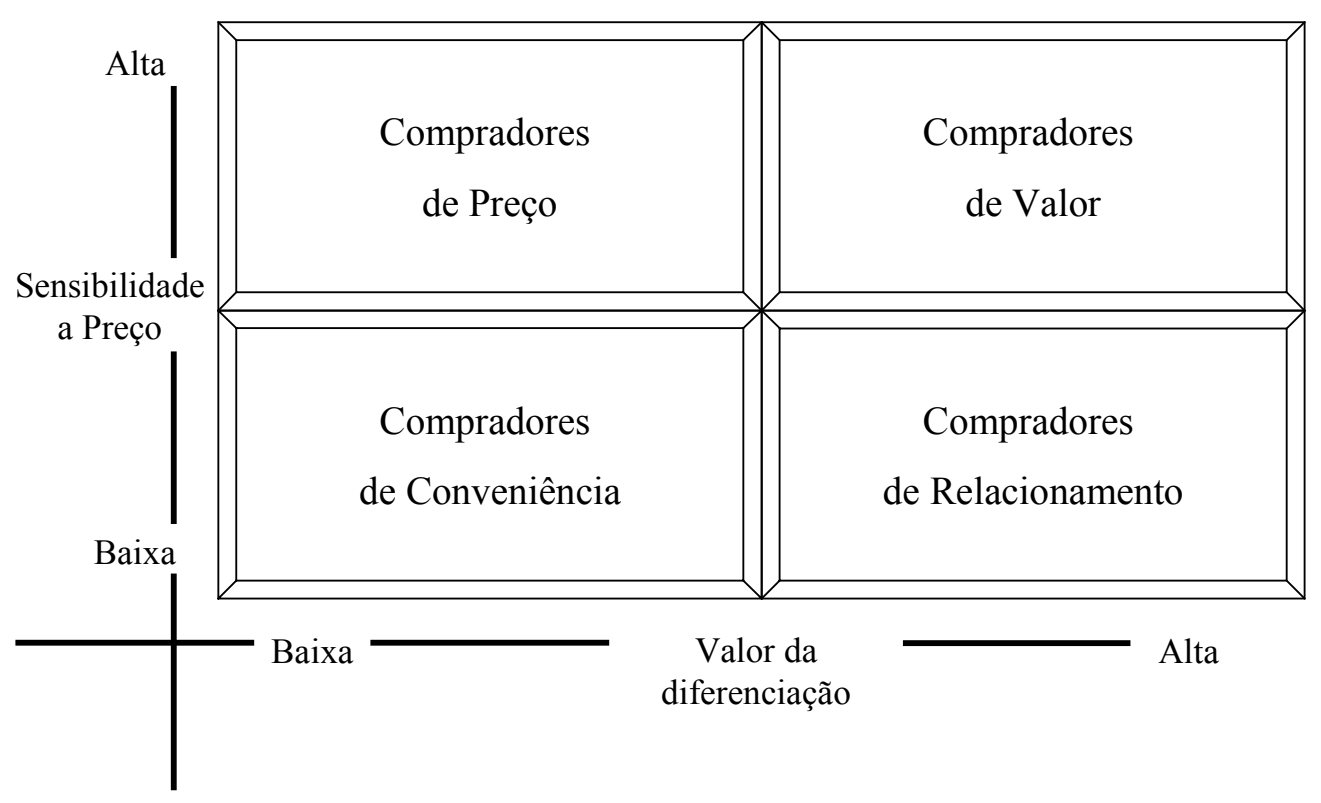

Fonte: Elaborado pela autora.

\section{Figura 7: Sensibilidade a preços}

Para mensurar a sensibilidade vários métodos podem ser aplicados. Lambin (2000a) agrupa esses métodos em quatro categorias principais: (i) o julgamento de especialistas (the expert judgement); (ii) pesquisas com consumidores; (iii) experimentos com preço e (iv) estudos econométricos. O julgamento de especialistas consiste em pedir para especialistas do mercado três estimativas ou pontos na curva de resposta ao preço, a menos realista, a mais realista e a associação do volume de vendas, mais as vendas esperadas a um preço médio.

As pesquisas com consumidores podem ser diretas ou indiretas. O método mais utilizado é o indireto por meio de análise conjunta. Os experimentos com preços são realizados em laboratórios ou no próprio campo (mercado) e os estudos econométricos são baseados em análises de painel ou séries temporais (LAMBIN, 2000a). 
Mensurar a elasticidade da demanda pode ser útil por diversas razões. A elasticidade fornece informações sobre a direção na qual os preços podem mudar, para simular a demanda e aumentar o faturamento. Além disso, comparar a elasticidade de marcas concorrentes identifica aquelas que podem resistir mais a um aumento de preço e, assim, revelar seu poder de mercado. Comparar a elasticidade de produtos de mesma categoria ajuda no ajuste de preço dentro da categoria e, por fim, a elasticidade cruzada ajuda a prever as mudanças na demanda de uma marca para outra (LAMBIN, 2000a).

Lambin (2000a), chama a atenção para algumas limitações que podem reduzir a utilidade prática dos métodos de mensuração. A elasticidade mede o relacionamento baseando-se no comportamento do consumidor, que só é observável depois do acontecimento. O seu valor preventivo depende da estabilidade das condições que ocasionaram a observação, portanto não pode ser utilizado para determinar o preço de novos produtos. Outro ponto é que, em muitas situações, o problema não é tanto saber como adaptar o preço a sensibilidade atual do mercado, mas sim saber de forma mudar essa sensibilidade para a direção procurada pela empresa. Nesse caso, é mais interessante saber o valor percebido do produto pelo grupo-alvo de consumidores. Por fim, a elasticidade mede o impacto do preço na quantidade comprada do produto, mas não mede o efeito do preço na propensão a experimentar o produto, em compras repetitivas, a taxas exclusivas entre outros, e essas são noções importantes para entender o mecanismo de resposta do consumidor em relação ao preço dos produtos.

É válido destacar que os métodos de mensuração da demanda foram desenvolvidos para modelos econômicos, para auxiliar mais no entendimento do comportamento econômico do que como uma ferramenta de decisão. Essa afirmação não significa, porém, que a teoria econômica não tenha relevância para o estudo da determinação do preço, pois mesmo sendo imprecisa, a estimativa da elasticidade do preço ajuda a determinar a direção da mudança de 
preço e seu impacto na receita de vendas. Contudo, os administradores de marketing deveriam desenvolver métodos de mensuração mais adequados às suas necessidades.

\subsubsection{Determinação de Preços Baseado na Demanda (Cliente)}

A fixação de preço baseado no cliente trabalha o preço de modo mais lucrativo e com a captura de mais valor, não necessariamente vendendo mais (aumento do volume de vendas). Além disso, leva em conta os preços que os consumidores estão dispostos a pagar e pode chegar a um montante que não reflete o verdadeiro valor do produto.

São utilizados o preço de valor e as estratégias flexíveis de apreçamento. O preço de valor representa a fixação de um preço baixo em relação à alta qualidade do produto quando comparado ao seu concorrente. Não é a simples redução do preço, requer uma reengenharia de operações, ou seja, um esforço de redução dos custos sem perder a qualidade (Lambin, 2000a; Lambin, 2000 b; Kotler; Keller, 2005).

Lambin (2000a) explica que, do ponto de vista do consumidor, um produto é o total de benefícios recebidos quando utilizado. Portanto, uma empresa orientada para o consumidor precisa fixar os seus preços de acordo com a percepção de benefícios e custos do cliente. Os consumidores comparam os benefícios de uma compra com o custo que ela representou. Quando o produto considerado apresenta a melhor relação custo-benefício, o consumidor está inclinado a comprar o bem. 
O procedimento de preço de valor pode ser implementado de duas formas diferentes. A primeira delas é o valor percebido. A idéia básica por trás desse método é o valor percebido no produto ou marca o qual irá determinar o nível de preço. O preço de valor percebido considera as percepções de valor dos clientes e não o custo do vendedor. Além disso, a estratégia utiliza os elementos do mix de marketing para aumentar o valor percebido pelo cliente e a chave para a sua determinação é a precisão na percepção do mercado relativa ao valor da oferta. É preciso determinar corretamente, por meio da pesquisa de marketing, a percepção do mercado em relação ao valor da oferta. Nesse caso é fundamental pensar-se no posicionamento do produto. Deve-se, ainda, mostrar ao consumidor porque o produto é mais caro (o valor que a oferta de fato representa).

A segunda maneira é o preço máximo aceitável, particularmente utilizado para determinar preços de produtos na indústria. O principal benefício para o comprador, nesse caso, é a redução de custos. O procedimento segue os seguintes passos: (i) entender o uso do produto pelo consumidor; (ii) analisar os benefícios gerados pelo produto; (iii) analisar os custos de aquisição e de uso do produto; (iv) calcular a relação custo-benefício e determinar o preço máximo aceitável (LAMBIN, 2000a). O preço mais alto que o consumidor estará disposto a pagar pelo produto é calculado por:

Benefícios - Custos $=$ Preço Máximo Aceitável

Algumas das limitações do apreçamento baseado no cliente referem-se à falha na percepção, que pode afetar a lucratividade da empresa a longo prazo e ao surgimento de alguns problemas quando os preços não refletem o montante que os clientes estão dispostos a pagar, 
pois alguns compradores sofisticados raramente são honestos a respeito de quanto estão dispostos a pagar por um produto. Para que a estratégia tenha um bom desempenho deve-se aumentar a disposição do cliente a pagar um preço que reflita o verdadeiro valor do produto.

As empresas não têm um preço único, mas sim uma variedade de preços adaptados a situações distintas de mercado. Para isso são utilizadas as estratégias flexíveis de mercado. Elas ocorrem em situações onde o mesmo produto é vendido para diferentes clientes a preços também diferentes e podem ser obtidas por região, por período, por forma do produto, ou de um segmento para outro.

Os economistas utilizam o termo descriminação de preços para designar as variações de preço que não são justificadas pelo custo (LAMBIN 2000b). As quatro formas de flexibilidade de preço são: (1) desconto para um segundo mercado, que acontece quando uma empresa tem excedente de produção e surge a oportunidade de vender seus produtos para um outro mercado e, nesse caso, o preço mínimo aceitável pela empresa deve ser o preço piso ou mínimo; (2) descontos periódicos ou sazonais, que permitem que a empresa explore a heterogeneidade da demanda - consumidores sensíveis e não sensíveis a preços, que compram o mesmo produto em períodos diferentes - vendendo com o preço alto no começo da temporada e oferecendo descontos sistemáticos no fim do período; (3) os descontos oferecidos ao acaso, ou seja, para situações onde existem empresas que vendem o mesmo produto a um preço alto e outras a um preço baixo e existem consumidores informados e desinformados quanto a essa diferença. A empresa estabelece um preço alto para vender aos clientes que não conhecem o preço inferior e ao mesmo tempo oferece descontos para atingir os consumidores que procuram pelo preço mais baixo; e (4) os preços promocionais, freqüentemente utilizados por varejos supermercadistas e lojas de departamentos, para estimular as vendas (TELLIS, 1986). 
Por fim, a empresa pode administrar seus preços ajustando-o às vendas realizadas sob diferentes condições, diferentes quantidades, diferentes tipos de intermediários, em diferentes regiões.

Depois de realizar a análise da demanda, o próximo passo para o estabelecimento de uma estratégia de preços é a estimativa de seus custos. Embora existam empresas que determinem o preço de seus produtos de modo a cobrir todos os seus custos, o resultado dessa conduta nem sempre é a lucratividade. Da mesma forma que os preços baseados apenas na demanda apresentam várias limitações, os preços baseados em custos também são passíveis de erros comuns, nem sempre levados em consideração pelas companhias. Por outro lado, não existe lucro sem que o preço determinado seja capaz de cobrir as principais despesas de um bem ou serviço. O próximo tópico aborda as questões críticas sobre análise de custos, que devem ser conhecidas pelos profissionais de marketing para o apreçamento estratégico correto de sua oferta.

\subsection{Estimativa de Custos}

"O preço estabelecido para um produto deve ser suficientemente alto para cobrir os custos envolvidos em sua fabricação e comercialização" (BOONE; KURTZ, 1998 p. 471). Estes custos são conhecidos como custos fixos, custos variáveis, custo total e custo marginal. Os custos fixos são aqueles que permanecem estáveis, independentemente do nível de produção, ao contrário dos variáveis que são os custos de matéria-prima e mão-de-obra, diretamente alocados à produção. O custo total é composto pelo somatório de todos os custos fixos e variáveis que, se dividido pela quantidade de unidades produzidas, resulta nos custos médios 
totais (BOONE; KURTZ, 1998; MCCARTHY; PERREAULT, 1997; MCGUIGAN, 1999). O custo marginal é a mudança no custo total, que resulta da produção de uma unidade adicional do produto (BOONE; KURTZ, 1998).

A divisão entre custos fixos e variáveis é o fundamento sobre o qual alicerça uma técnica contábil-financeira usada na análise de investimentos e também na fixação de preços. É o estudo do ponto de breakeven. Este ponto é aquele no qual receita e custos se equilibram, abrindo caminho para a região dos lucros. O ponto de equilíbrio ou de paridade e custovolume-lucro são expressões empregadas com o mesmo significado de ponto de breakeven (LEPSCH, 1996). Entretanto a técnica apresenta algumas deficiências. Ela supõe linearidade da receita e do custo; trabalha com apenas um produto; classifica os custos em fixos e variáveis apenas; não considera despesas com pesquisa e desenvolvimento (P\&D) e promoção institucional, que são realizadas durante vários períodos para gerar aumento da receita.

Jain (2000), explica que para estudar o impacto dos custos na estratégia de apreçamento, os seguintes relacionamentos devem ser considerados: (i) a proporção dos custos fixos para os custos variáveis; (ii) a economia de escala disponível para uma empresa e (iii) a estrutura de custos de uma empresa versus a do concorrente. Se os custos fixos de uma companhia em comparação com os seus custos variáveis formam uma alta proporção dos seus custos totais, adicionar o volume de vendas será de grande ajuda para o aumento dos ganhos, ou seja, se os custos fixos forem cobertos, qualquer aumento no volume gera um ganho. Em setores onde os custos variáveis são de maior proporção no custo total, pode-se afirmar que estes são setores sensíveis a preço porque, mesmo um pequeno aumento no preço, gera um ganho enorme.

Os custos variam em diferentes níveis de produção e para o apreçamento ser adequado à empresa deve saber como seus custos variam conforme o nível em que se encontra. (KOTLER; KELLER, 2005). Os seus custos reduzirão conforme o aumento da quantidade 
produzida, pois os custos fixos irão diluir. A partir de certo momento, a fábrica torna-se ineficiente com a maior freqüência de quebra das máquinas e escassez de espaço físico. Existe dessa forma, para os dados recursos, uma quantidade ideal de produção.

O comportamento dos custos em função da produção acumulada é resultante da curva de experiência ou curva de aprendizagem, ou seja, quando a empresa reduz o custo total médio em função do aprendizado, conquistado com o aumento da produção e a experiência adquirida. É também conhecida pelos economistas como a economia de escala (figura 8). Esta situação acontece quando a empresa aprende como produzir da melhor forma, seus funcionários aprendem a reduzir os custos evitando erros e uso inadequado de materiais ou equipamentos e melhorando o tempo de produção, o fluxo de materiais e compras etc (HENDERSON, 1984).

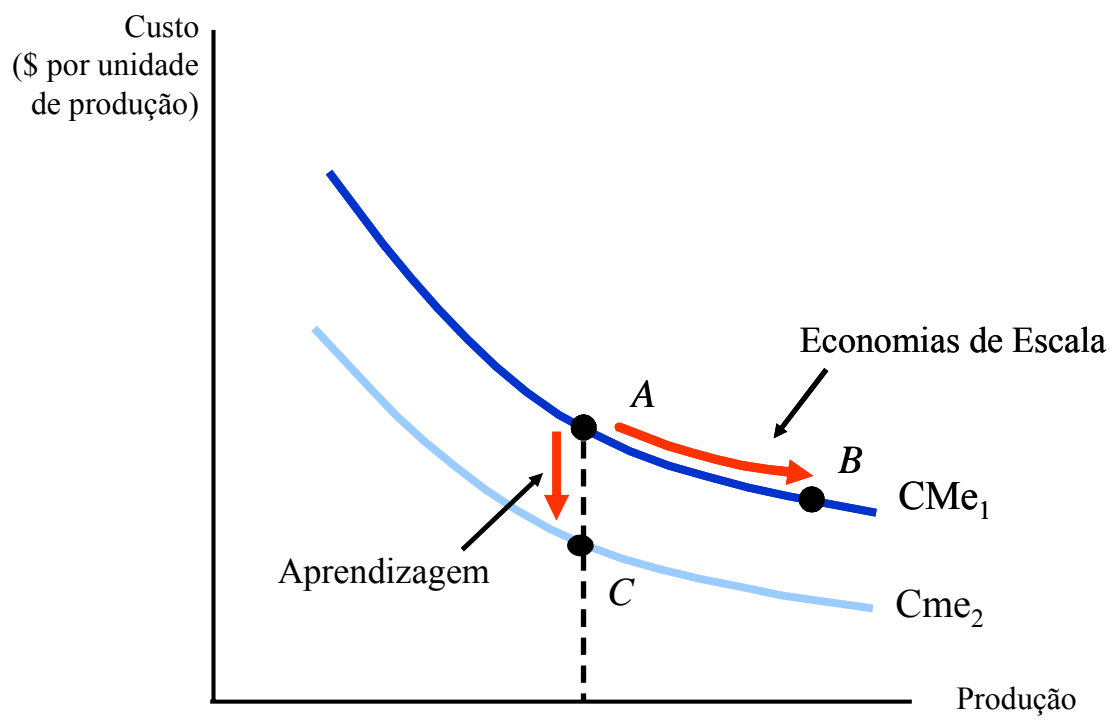

Fonte: Elaborado pela autora a partir de Henderson (1984), Pyindick e Rubinfeld (2002), Besanko, Dranove e Shanley (2000).

\section{Figura 8: Economia de Escala X Aprendizagem}


Pyindick e Rubinfeld (2002), explicam que uma empresa apresenta economia de escala quando é capaz de duplicar a sua produção com menos do que o dobro de seus custos. Besanko, Dranove e Shanley (2000), afirmam que o processo de produção de um bem ou serviço específico apresenta economia de escala em uma série de itens produzidos, quando o custo médio declina com esse conjunto de itens.

Se a economia de escala obtida da produção de uma companhia for substancial, a empresa deve planejar expandir sua participação de mercado e, com respeito a preços a longo prazo, aceitar declínios esperados no faturamento. Alternativamente, é esperado que as operações da empresa produzam um declínio nos seus custos, então os preços podem ser abaixados no longo prazo para ganhar participação de mercado mais alta (JAIN, 2000).

Caso o fabricante seja um produtor de custo baixo, em relação aos seus concorrentes, ele irá ganhar lucros adicionais por manter o preço em um nível competitivo.Os lucros adicionais podem ser utilizados para promover os produtos com mais agressividade e aumentar a participação do negócio como um todo. Se, por acaso, os custos do fabricante forem altos em comparação com seus concorrentes, a empresa não está em posição favorável à redução de preços, porque esta tática pode levar a uma guerra de preços que ela, provavelmente, irá perder (JAIN, 2000).

Além da economia de escala verifica-se também a economia de escopo, quando a produção conjunta de dois produtos por parte de uma única empresa é maior do que a produção que seria obtida por duas empresas diferentes, cada uma produzindo um único produto. Nesse caso, ambos os produtos usam capital e trabalho, a fabricação dos dois produtos compartilha recursos administrativos, a fabricação dos dois produtos requer o mesmo tipo de equipamento e mão de obra com qualificação semelhante (PYINDICK; RUBINFELD, 2002; BESANKO; DRANOVE; SHANLEY, 2000). 
O grau da economia de escopo mede a economia de custos proporcionada pela produção conjunta e é representado pela seguinte fórmula:

$$
\mathrm{ESC}=\frac{\mathrm{C}\left(Q_{1}\right)+C\left(Q_{2}\right)-C\left(Q_{1}, Q_{2}\right)}{C\left(Q_{1}, Q_{2}\right)}
$$

Sendo que $\mathrm{C}(\mathrm{Q} 1)$ é o custo de produzir Q1, C(Q2) é o custo de produzir Q2 e, por fim, $\mathrm{C}(\mathrm{Q} 1 \mathrm{Q} 2)$ é o custo de produzir conjuntamente os dois produtos.

Uma estrutura de custos é proposta por Lambin (2000b), que tem como base os custos internos, sem a interferência do mercado. Os três tipos de custos considerados são (i) o custo mínimo: custo direto que só permite a recuperação do valor de gasto na fabricação do produto, significando margem igual a zero; (ii) o custo técnico que corresponde ao nível de atividade em que a empresa cobre os custos diretos e os custos fixos, o que permite, além da recuperação do valor de gasto na fabricação do produto, a cobertura dos encargos de estrutura e (iii) o custo-alvo ou preço suficiente que compreende a condição de lucro. Entretanto, ao ignorar o mercado, as empresas deixam de levar em consideração a sensibilidade da demanda e ficam dependentes da meta de vendas para atingir as margens desejadas.

Jain (2000) concorda com a importância dos custos fixos e variáveis para o apreçamento, mas afirma que outros custos também devem ser considerados. Custos incrementais, custos de oportunidade, custos de substituição, custos “out-of-pocket" e custos controláveis. Entretanto, Nagle e Holden (2003), afirmam que compreender os custos não significa simplesmente conhecer os seus montantes. Os autores argumentam que até os profissionais de apreçamento menos eficazes, que aplicam fórmulas de custo mais margem adicional, sabem o quanto é gasto com mão-de-obra, matérias-primas e despesas em geral. 
Os gerentes que realmente compreendem seus custos, sabem como tais custos mudarão com modificações nas vendas resultantes da determinação estratégica de preços. Nagle e Holden (2003), ainda complementam considerando que nem todos os custos são relevantes para a decisão de apreçamento e o primeiro passo é identificar quais são os custos importantes, ou seja, os que de fato determinam o impacto no lucro. Os autores consideram que os custos realmente relevantes são os incrementais (não a média) e evitáveis.

Os custos incrementais são aqueles associados às mudanças no apreçamento e nas vendas. Os custos variáveis são considerados incrementais quando resultam diretamente de uma implementação de uma alteração de preço ou do oferecimento de uma versão do produto em outro nível de preço. Entretanto, é importante ressaltar que, muitos custos não são puramente fixos, nem puramente variáveis (NAGLE, HOLDEN, 2003). Eles são fixos em uma faixa de vendas e variam quando as vendas ultrapassam essa faixa e determinar se esses custos "semifixos" são incrementais é condição para que a decisão de apreçamento seja tomada corretamente.

Os custos evitáveis são aqueles que não foram incorridos ou que ainda podem ser revertidos, ou seja, os custos para vender um produto, para entregá-lo ao consumidor e recolocar o item vendido no estoque são considerados evitáveis, assim como, os custos de aluguel de instalações e equipamentos que não são cobertos por arrendamento a longo-prazo. A maneira mais fácil de identificar se o custo é, de fato evitável, é reconhecendo se ele é o custo futuro e não o custo histórico associado à realização de uma venda (NAGLE, HOLDEN, 2003; CHURCHILL, 1982). 
Lambin (2000a), explica que os preços determinados a partir dos custos e que não fazem qualquer referência aos fatores do mercado são denominados preços baseados em custos. A seguir estão expostas as estratégias de apreçamento utilizadas pelas empresas, com base nos custos.

\subsubsection{Determinação de Preços Baseados em Custos}

A análise de custos identifica quatro tipos de preços baseados em custos, cada um respondendo por um custo específico e pela necessidade de lucro. O primeiro é o preço-piso, ou seja, o preço mínimo que pode ser cobrado, pois cobre somente os custos de fabricação do produto, oferecendo margem zero a empresa. Esse conceito de preço é utilizado para pedidos excepcionais, descontos de mercado quando a empresa tem a oportunidade de vender para um mercado novo ou terá perdas grandes em suas vendas no seu mercado principal. Pode ser também denominado preço marginal (LAMBIN, 2000a).

O segundo tipo é o preço de equilíbrio, que cobre tanto os custos fixos quanto os custos diretos, dado o volume de vendas assumido. É calculado, geralmente, para diferentes níveis de volume. Isto define uma escala de preços mínimos.

Lambin (2000a) apresenta o terceiro tipo como o preço-alvo ou suficiente. Ele inclui, além dos custos diretos e fixos, um lucro, que é determinado por uma referência a uma taxa normal de retorno no capital investido, ou por um nível de atividade assumido. Como no preço de equilíbrio, este tipo de preço baseado em custo, também depende do volume de atividade que está sendo considerado. 
Por fim, apresenta-se o preço de mark-up, que é calculado adicionando-se uma margem padrão ao preço de equilíbrio. Assumindo que a empresa queira ganhar $20 \%$ de margem sobre suas vendas, o mark-up é dado por:

\section{Preço de Mark-up: Preço de Equilíbrio/(1 - margem desejada)}

Este método de apreçamento, popular pela sua simplicidade, ignora a demanda e a concorrência. Ele somente irá funcionar caso o volume de vendas seja atingido (LAMBIN, 2000a; LAMBIN, 2000b; KOTLER; KELLER, 2005).

Os métodos de apreçamento baseados em custo conduzem a preços além do devido em mercados mais fracos e a preços abaixo do devido em mercados mais fortes, o que é considerado pelos estudiosos da área como sendo exatamente a direção oposta de uma estratégia prudente. O principal problema é definir a grandeza da margem que deverá cobrir todas as despesas e permitir retorno.

Depois de realizada a análise da demanda e a estimativa dos custos da empresa, o próximo passo é conhecer as ações da concorrência. A seguir discute-se a importância e a influência dos competidores na determinação do apreçamento estratégico de uma empresa.

\subsection{Análise dos Custos, Preços e Ofertas dos Concorrentes}

Uma empresa precisa comparar seus custos com os custos de seus competidores para saber em que nível opera e se está em vantagem ou desvantagem em relação a eles (BESANKO; 
DRANOVE; SHANLEY, 2001; GRANT, 2002; PORTER, 1980). Também é necessário conhecer o preço e a qualidade das ofertas concorrentes, pois esse será um ponto de referência para a fixação de seu preço. Isso porque a estratégia de apreçamento é muito influenciada pela situação da concorrência, que é caracterizada pelo número de empresas que atuam no mesmo segmento (LAMBIN, 2000a; PORTER, 1980; PORTER, 1992; JAIN, 2000) e do valor percebido do produto, resultante dos esforços de diferenciação produzidos pela empresa com o objetivo de alcançar uma vantagem concorrencial (LAMBIN, 2000a).

O mercado é o foco da atividade econômica. Devido a sua relevância na formação de preços e alocação de recursos, os administradores dão grande importância às estruturas de mercado dos diferentes bens e serviços. Tradicionalmente, classificam-se os mercados em quatro estruturas básicas: concorrência perfeita, monopólio, oligopólio e concorrência monopolística. Existe monopólio quando há um único vendedor de uma mercadoria, não há substitutos próximos para os bens e existem obstáculos quanto à entrada na indústria, que podem ser de várias naturezas, tais como (MANKIW, 1999):

- O mercado é limitado e não comporta mais do que uma firma;

- A firma existente segue uma política de preços planejada para reduzir a atração de novos concorrentes;

- A firma possui o controle sobre a matéria-prima, canais de distribuição ou sobre o processo de produção (patentes);

- A firma opera com licença do governo ou em sistema limitante da produção tal como cotas.

Mankiw (1999), explica que a concorrência monopolística ocorre quando há muitos vendedores de bens substitutos próximos, mas não perfeitos e o cliente baseia suas decisões tanto em relação ao preço, quanto em relação às especificidades dos produtos. 
Um mercado monopolisticamente competitivo tem duas características importantes: (1) tratase de um ambiente comercial no qual as empresas competem vendendo produtos diferenciados, altamente substituíveis uns pelos outros, mas que não são, entretanto, substitutos perfeitos e (2) trata-se de um mercado de livre entrada e saída - é relativamente fácil a entrada de novas empresas com suas próprias marcas de produto e a saída de companhias que nele atuam, caso seus produtos deixem de ser lucrativos (PINDYCK; RUBINFIELD, 2002).

O oligopólio é uma estrutura de mercado que caracterizada pela existência de um pequeno, mas suficiente número de firmas, e por isso mesmo, interdependentes, ou seja, cada uma considera como suas ações afetariam as políticas das rivais (PINDYCK; RUBINFIELD, 2002). Pindyck e Rubinfeld (2002), afirmam que, em um mercado oligopolístico, o produto pode ou não ser diferenciado. O que importa é que apenas algumas poucas empresas são responsáveis pela maior parte ou pela totalidade da produção. Em alguns desses mercados, algumas ou todas as empresas auferem lucros substanciais a longo prazo, já que barreiras à entrada tornam difícil ou impossível que novas companhias entrem no mercado.

Mankiw (1999), explica que na concorrência perfeita pressupõe-se que os vendedores e compradores são suficientemente numerosos e atomizados de tal sorte que nenhum deles isoladamente é capaz de exercer influência significativa sobre o preço da mercadoria. Existe homogeneidade nas mercadorias, isto é, os consumidores não percebem diferenças em relação aos diversos produtos ofertados no mercado, as mercadorias são "commodities", não há interferência na livre determinação dos preços dos produtos e fatores de produção, tanto produtores quanto consumidores tem conhecimento dos preços e quantidades de produtos oferecidos no mercado. 
Este modelo trata-se de uma abstração teórica que é dificilmente encontrado no mundo real. Um exemplo próximo deste tipo de mercado são as feiras livres de produtos agrícolas, nas quais os clientes podem estar informados de todos os preços praticados para cada tipo de produto, os quais são homogêneos.

No que refere à geração de preços, como discutido, o nível de preços será diretamente proporcional à demanda do produto ou serviço em questão e, inversamente proporcional à oferta dos mesmos. Cada agente econômico é incapaz de, isoladamente, afetar de modo significativo, o preço do produto (quadro 2). Este dependerá das ações e reações do conjunto de agentes como um todo. (MANKIW, 1999).

\section{Quadro 2: Características determinantes de cada estrutura de Mercado}

\begin{tabular}{|c|c|c|c|c|}
\hline & Produto & No. de empresas & $\begin{array}{c}\text { Barreiras de } \\
\text { entrada }\end{array}$ & $\begin{array}{c}\text { Capacidade de } \\
\text { influenciar o preço }\end{array}$ \\
\hline $\begin{array}{c}\text { Concorrência } \\
\text { Perfeita }\end{array}$ & Homogêneo & Muitas & Sem barreiras & Não \\
\hline Monopólio & Homogêneo & Apenas uma & Com barreiras & Sim \\
\hline Oligopólio & Homogêneo & Poucas & Com barreiras & Sim \\
\hline $\begin{array}{c}\text { Concorrência } \\
\text { Monopolística }\end{array}$ & Diferenciado & Muitas & Sem barreiras & Sim \\
\hline
\end{tabular}

Fonte: elaborado pela autora com base em Mankiw (1999) e Pindyck e Rubinfield (1999).

Portanto, mercados são freqüentemente descritos como sendo concentrados (com poucos vendedores) ou desconcentrados (muitos vendedores). Essas caracterizações permitem uma 
rápida e acurada avaliação da natureza da competição em um mercado (BESANKO; DRANOVE; SHANLEY, 2000).

Sobre o valor percebido do produto, Lambin (2000a) apresenta, no quadro 3, dois níveis de intensidade relacionadas com esse valor, permitindo assim, quatro situações distintas nas decisões de preço em face dos tipos de concorrência existentes.

\section{Quadro 3: As decisões de preço em função da concorrência}

\begin{tabular}{|c|c|c|}
\hline \multirow{2}{*}{$\begin{array}{c}\text { Valor Percebido do } \\
\text { Produto }\end{array}$} & \multicolumn{2}{|c|}{ No. de Competidores } \\
\cline { 2 - 3 } & Baixo & Alto \\
\hline Alto & $\begin{array}{c}\text { Monopólio ou Oligopólio } \\
\text { Diferenciado }\end{array}$ & $\begin{array}{c}\text { Concorrência } \\
\text { Monopolística }\end{array}$ \\
\hline Fraco & $\begin{array}{c}\text { Oligopólio } \\
\text { Indiferenciado }\end{array}$ & $\begin{array}{c}\text { Concorrência Pura ou } \\
\text { Perfeita }\end{array}$ \\
\hline
\end{tabular}

Fonte: Adaptado de Lambin, 2000a.

Quando o número de competidores é baixo e o valor percebido do produto é alto, a estrutura de mercado está próxima do monopólio ou oligopólio diferenciado. O preço, nesse caso, é uma ferramenta para a empresa, a qual possui a margem para manobra que pode variar com o valor percebido do comprador sobre os atributos de diferenciação. 
No outro extremo, onde o número de concorrentes é alto e os produtos possuem baixo grau de diferenciação (commodities), a estrutura é próxima da competição perfeita. Nessa situação os preços são amplamente determinados pela lei da oferta e demanda. A empresa não tem, praticamente, nenhuma autonomia sobre as estratégias de apreçamento.

Uma terceira situação, que apresenta baixo número de competidores e baixo valor percebido, corresponde ao oligopólio indiferenciado. A interdependência dos concorrentes, nesse caso, é alta, limitando a autonomia das empresas sobre os preços praticados. O preço tende a estar alinhado com o oferecido pelo líder de mercado.

Finalmente, na última alternativa, têm-se produtos altamente diferenciados, oferecidos por um grande número de empresas. É a chamada concorrência monopolística, onde existem alguns graus de autonomia, que podem ser limitados pela intensidade competitiva.

A suposição da existência de um grande número de consumidores e produtores, associada à informação perfeita, livre entrada e saída do mercado e comercialização de produtos homogêneos, conduz à conclusão que os preços devem ser iguais entre todas as empresas que operam no mercado (condição de concorrência perfeita). Entretanto é importante destacar que isso representa uma condição ideal de mercado, difícil de verificar na prática.

Lepsch (1996) afirma que a estrutura de mercado e a estratégia competitiva examinam uma ampla gama de mercados e explicam de que forma as decisões de preço, investimento e nível de produção das empresas dependem da estrutura de mercado e do comportamento dos seus concorrentes. A essência da formulação de uma estratégia competitiva é relacionar uma empresa ao seu meio ambiente. 
A organização se expressa à comunidade por meio de seus produtos e a falta de competitividade ameaça sua sobrevivência no longo prazo. A sobrevivência de um produto no longo prazo significa que os estímulos gerados pelos fatores do macroambiente têm de estar coerentes com sua estratégia de negócios e política de preços. Portanto, as decisões da gerência sobre apreçamento devem estar coerentes com o ambiente ao qual estão relacionadas. Lambin (2000a), complementa ao afirmar que as estruturas de mercado são muito diferentes e podem ser observadas nos vários estágios do ciclo de vida dos produtos.

Jain (2000) considera que, além do número de empresas que atuam no mesmo segmento e do valor percebido do produto, é importante analisar o tamanho da indústria e a facilidade de entrada no mercado. $\mathrm{O}$ autor apresenta treze informações sobre os concorrentes que são necessárias para estabelecer a estratégia de preço de um produto por uma empresa:

1. Listas de preços dos concorrentes já publicadas e propaganda;

2. Reações a mudanças de preço no passado (dos concorrentes);

3. Tempo em que os concorrentes mudam seus preços e os fatores que iniciam essa mudança;

4. Informações sobre campanhas especiais dos concorrentes;

5. Comparação com a linha de produto dos concorrentes;

6. Suposições sobre estratégias de preço utilizadas pelos concorrentes e seus objetivos de marketing;

7. Relatórios de desempenho financeiro dos concorrentes;

8. Estimativa de custos dos concorrentes (fixos e variáveis);

9. Retaliações de preço esperadas;

10. Análise da capacidade de retaliação da concorrência;

11. Viabilidade financeira de enfrentar uma guerra de preços; 
12. Postura estratégica dos competidores;

13. Agressividade do competidor.

Dada a demanda dos consumidores, a função custos e preços dos concorrentes, a empresa estará preparada para selecionar um método de estabelecimento de preço, que inclua uma ou mais dessas três considerações.

\subsection{Seleção de um Método de Estabelecimento de Preço}

A fixação de preços no Brasil sofreu modificações a partir dos anos 90 devido às novas tecnologias, o relacionamento com fornecedores e compradores e o aumento da concorrência. Durante os anos 60, 70 e 80, o apreçamento era de responsabilidade da área financeira e contábil das empresas. Os responsáveis pela maior preocupação com ações destinadas a cortar custos e a procura por criar valor para o consumidor foram o aumento da competitividade e a busca de novas estratégias de diferenciação, de conquista e busca da lealdade dos consumidores. Na denominada economia moderna, para prosperar, a empresa deve oferecer valor para o consumidor nos seus produtos ou serviços, de forma competitiva, cobrindo os seus custos e gerando retorno para os seus acionistas. Para que isso seja possível é preciso que a empresa tenha conhecimento sobre os diferentes métodos de estabelecimento de preço e assim, selecionar aquele que melhor se adapte aos objetivos por ela escolhidos.

Analisar os custos e demanda da empresa é essencial para a fixação correta do preço de um produto ou serviço. Entretanto, de nada adianta se o preço estabelecido pela companhia, que utilizou os métodos propostos, não for adequado ao que o consumidor-alvo está disposto a 
pagar para adquiri-lo. Kotler e Keller (2005), exibem o modelo dos “3 C's" - custos, concorrentes e clientes - como as três principais considerações para selecionar um preço (figura 9).

Os custos representam o "piso", ou seja, o mínimo cobrado por um produto e é igual ao montante capaz de cobrir seus custos totais. Abaixo desse nível, qualquer lucro é considerado impossível para a empresa. Por outro lado, o "teto" é o máximo que se deve fixar, pois representa a quantia de dinheiro que o cliente está disposto a desembolsar para a compra do item.

\begin{tabular}{|c|c|c|c|c|}
\hline Preço Baixo & Custo & $\begin{array}{l}\text { Preços dos } \\
\text { concorrentes }\end{array}$ & $\begin{array}{l}\text { Percepção } \\
\text { pelos }\end{array}$ & Preço Alto \\
\hline $\begin{array}{l}\text { Lucro } \\
\text { impossível } \\
\text { neste preço }\end{array}$ & 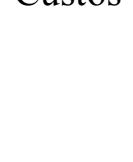 & $\begin{array}{c}\text { e dos } \\
\text { substitutos }\end{array}$ & $\begin{array}{c}\text { consumidores } \\
\text { de oferta } \\
\text { única }\end{array}$ & $\begin{array}{c}\text { Demanda } \\
\text { impossível } \\
\text { neste } \\
\text { preço }\end{array}$ \\
\hline
\end{tabular}

Fonte: Adaptado de Kotler e Keller (2005).

Figura 9: O modelo dos 3 C's para a determinação de preços.

O equilíbrio é o preço oferecido pelo mercado pela a mesma mercadoria ou produto com características semelhantes (bens substitutos). Kotler e Keller (2005) estipulam seis métodos de determinação de preços. No quadro 4 esses métodos e suas características são resumidamente apresentados, já que suas características foram discutidas anteriormente. 


\section{Quadro 4: Método de Determinação de Preços - características e limitações.}

\begin{tabular}{|c|c|}
\hline $\begin{array}{c}\text { Método de } \\
\text { Determinação de Preço }\end{array}$ & Características e Limitações \\
\hline Mark up & $\begin{array}{l}\text { - Método de simples acréscimo de margem padrão ao custo do produto para } \\
\text { formar o preço de venda. } \\
\text { - Popular porque os vendedores têm mais certeza dos custos do que da } \\
\text { demanda, o cálculo é simples quando os custos se alteram, quando todas as } \\
\text { empresas usam o método, os preços tendem a ser similares. } \\
\text { - Os preços são mais altos em itens sazonais (para cobrir risco de encalhe), } \\
\text { de especialidade, de giro lento, com custos altos de estocagem e } \\
\text { movimentação e também em itens de demanda inelástica, e também é alto } \\
\text { com produtos de custos ocultos ou altamente variáveis. }\end{array}$ \\
\hline Preço de Retorno-Alvo & $\begin{array}{l}\text { - As empresas determinam o preço que assegura a sua taxa alvo de retorno } \\
\text { sobre o investimento (ROI), o fabricante realizará o ROI pretendido se seus } \\
\text { custos e vendas estimadas forem precisos. } \\
\text { - Importância do cálculo do Ponto de Equilíbrio para que se saiba o que } \\
\text { pode acontecer caso a previsão de vendas não se concretize. } \\
\text { - Ignora a elasticidade de preços e preços dos concorrentes. }\end{array}$ \\
\hline Preço de Valor Percebido & $\begin{array}{l}\text { - As percepções de valor dos compradores, não custos, são fatores-chave } \\
\text { para determinar preço. } \\
\text { - A chave para o uso de valor percebido é determinar corretamente por meio } \\
\text { da pesquisa de marketing a percepção do mercado em relação ao valor da } \\
\text { oferta. } \\
\text { - É fundamental o pensamento do posicionamento do produto. } \\
\text { - Medir o valor percebido de cada um dos benefícios do produto: } \\
\text { (apreçamento pelos componentes de valor) durabilidade, confiabilidade, } \\
\text { serviço superior, garantia em peças, entre outros. } \\
\text { - Deve-se mostrar ao consumidor porque o produto é mais caro, ou seja, o } \\
\text { valor que a oferta de fato representa. }\end{array}$ \\
\hline Preço de Valor & $\begin{array}{l}\text { - A fixação de um preço baixo em relação à alta qualidade do produto } \\
\text { quando comparado ao seu concorrente. } \\
\text { - Não é a simples redução do preço, mas sim um esforço de redução dos } \\
\text { custos sem perder a qualidade. }\end{array}$ \\
\hline $\begin{array}{l}\text { Preço de Seguidor do } \\
\text { Concorrente }\end{array}$ & $\begin{array}{l}\text { - A empresa baseia seu preço em função dos preços cobrados pelos } \\
\text { concorrentes, dedicando menor atenção aos custos ou à demanda. }\end{array}$ \\
\hline Preço de Licitação & $\begin{array}{l}\text { - A fixação do preço é fortemente orientada para a concorrência. } \\
\text { - Maior o preço menor serão as chances da empresa de vencer a licitação, } \\
\text { sendo possível o cálculo do lucro esperado de cada alternativa de preço com } \\
\text { as respectivas probabilidades de vitória. }\end{array}$ \\
\hline
\end{tabular}

Fonte: Elaborado a partir de Kotler e Keller (2005) e Lambin (2000b) 
Urdan e Urdan (2006), afirmam que o caminho para o apreçamento é a gestão integrada de preços, que contempla os diversos fatores relevantes e consolida a competência gerencial no processo de fixação de preços. A figura 10 mostra os elementos básicos da gestão integrada. A base do trabalho é a análise de custos internos, concorrência, demanda e consumidor.

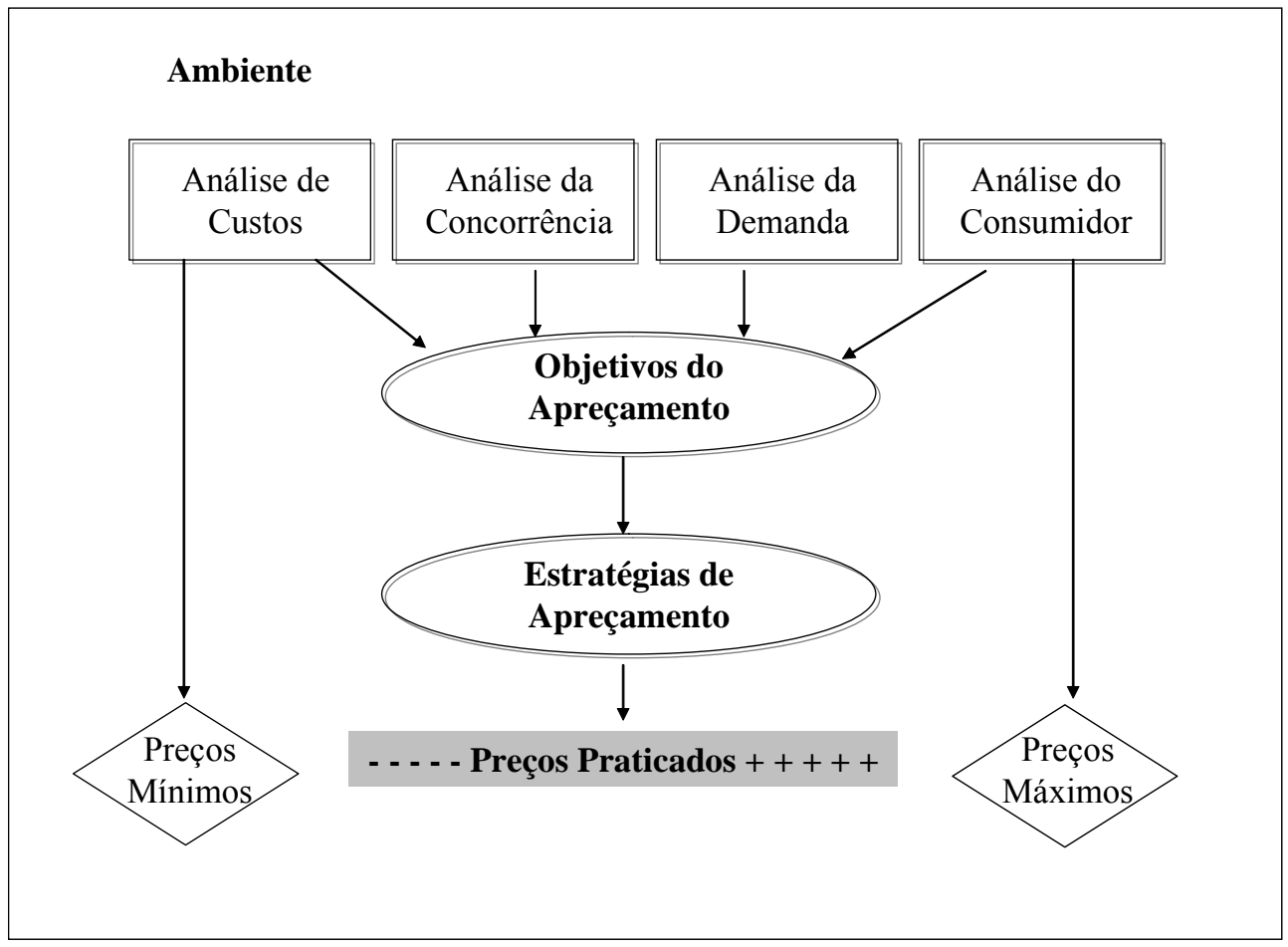

Fonte: Urdan e Urdan (2006).

Figura 10: Elementos básicos da gestão de preços.

Urdan e Urdan (2006), argumentam que este conhecimento identifica as forças e as fraquezas da organização e oportunidades e ameaças no ambiente com influência nas decisões de precificação. Com o contexto mapeado, são definidos os objetivos que apontam as estratégias viáveis, num binômio integrado. 
Assim como no modelo dos 3C's, apresentado na figura 9, o custo também representa o mínimo cobrado, abaixo do qual não existe viabilidade financeira a longo prazo. A demanda e o cliente formam o teto, além do qual não se consegue vender e, entre esses dois pontos, a empresa seleciona os preços mais adequados, de acordo com os objetivos e as estratégias adotados (URDAN; URDAN, 2006).

Após selecionar o método de apreçamento, a empresa deverá considerar outros fatores que irão influenciar na fixação do preço final de seus produtos. A seguir discute-se quais são os fatores adicionais ,em que situações eles devem ser levados em conta e quais são as técnicas que melhor se encaixam em cada circunstância que a empresa enfrenta.

\subsection{Seleção do Preço Final}

À medida que os métodos de fixação de preços forem se consolidando no nível a partir do qual a empresa estabelecerá seu preço final, alguns fatores adicionais devem ser considerados (KOTLER; KELLER, 2005). Esses fatores são (i) o preço psicológico, (ii) a influência de outros elementos do composto de marketing, (iii) a política de determinação dos preços da empresa, (iv) o impacto de preços sobre terceiros e (v) determinação de preços por compartilhamento de ganhos e riscos.

No preço psicológico a associação do preço alto com a qualidade, conduz a empresa a colocar o seu produto com o preço entre os mais caros do segmento. Ao analisar a influência de outros elementos do composto de marketing na formulação de seu preço final, a empresa deve considerar a qualidade da marca e da propaganda em relação à concorrência. Existe um 
relacionamento positivo entre preço alto e orçamento de propaganda. Os consumidores geralmente estão dispostos a pagar mais por produtos conhecidos do que por desconhecidos (FRAM; McCARTHY, 1999; LAMBIN, 2000a; KOTLER; KELLER, 2005).

Sobre as políticas de preço da empresa é importante ressaltar que o preço deve ser consistente com tais políticas, com a finalidade de assegurar que a força de vendas trabalhe com preços atrativos para os clientes e, ao mesmo tempo, rentáveis para a empresa. Algumas empresas são a favor da cobrança de multas sob determinadas situações (FRAM; McCARTHY, 1999).

Com relação ao impacto de preços sobre terceiros, a empresa deverá considerar a reação das outras partes envolvidas e interessadas (URBANY, 2001), tais como distribuidores e os revendedores e, por fim, na determinação de preços por compartilhamento de ganhos e riscos, os compradores podem relutar em aceitar uma oferta, caso percebam muito risco no negócio, assim, o vendedor pode propor absorver parte desse risco ou mesmo a sua totalidade, se não entregar o valor prometido ao cliente (FRAM; McCARTHY, 1999; LAMBIN, 2000a; KOTLER; KELLER, 2005).

A discussão sobre a seleção do preço final encerra as etapas para estabelecer o preço de venda de um produto. Entretanto, as empresas, geralmente, não determinam um preço único, mas elaboram uma estrutura de determinação de preços que reflete as variações geográficas na demanda e nos custos, as exigências de segmento de mercado, as oportunidades de compra, os níveis de pedidos, a freqüência de entrega, as garantias, os contratos de serviços, entre outros fatores. Devido aos descontos ou ao apoio promocional, raramente as companhias realizam o mesmo lucro sobre cada unidade vendida. Existem várias estratégias que permitem a adequação de preços a situações distintas (KOTLER; KELLER, 2005). Essas estratégias são apresentadas e discutidas a seguir. 


\subsection{Estratégias de Adequação do Preço}

Influenciados pelas variações do ambiente, pelas saturações de mercado com baixa taxa de crescimento, pela competição global e pelo movimento dos consumidores, muitas empresas estão aderindo a diferentes formas de adequação do preço. Tais empresas elaboram estratégias de adequação de preços que refletem variações principalmente na demanda e nos custos.

Existem várias estratégias de adequação de preços, tais como: preço geográfico, preços com descontos, preço promocional, preço discriminatório e preço de mix de produtos. O quadro 5 apresenta cada uma dessas práticas e suas principais características.

As empresas procuram apresentar preços diferentes de seus produtos para consumidores localizados em regiões distintas. Esta diferenciação acontece devido a diversos fatores como: (i) diferentes custos de armazenagem, transporte e entrega; (ii) preferências de seus consumidores naquela região, (iii) os concorrentes locais. É a chamada estratégia de preço geográfico. Alguns clientes, por exemplo, preferem a permuta como prática de pagamento. A permuta pode representar de $15 \%$ a $20 \%$ do comércio mundial (KOTLER; KELLER, 2005) e assume as seguintes formas: escambo, acordo de remuneração, acordo de recompra e reciprocidade.

Na reciprocidade, o vendedor recebe seu pagamento total em dinheiro, porém com a condição de despender uma quantia naquele país durante um período de tempo pré-estabelecido (KOTLER; KELLER, 2005; LAMBIN, 2000a). 
Quadro 5: Estratégias de Adequação de Preços

\begin{tabular}{|c|c|}
\hline $\begin{array}{c}\text { Estratégias de Adequação do } \\
\text { Preço }\end{array}$ & Considerações \\
\hline Preço geográfico & $\begin{array}{l}\text { Considera os custos de transporte até o consumidor, } \\
\text { esses custos crescem em importância quando o frete se } \\
\text { torna uma parte maior do custo variável total. Existem } \\
\text { duas estratégias geográficas: } \\
\text { 1.Por ponto de produção, pois o produto é retirado na } \\
\text { fábrica. } \\
\text { 2. Preço de entrega uniforme, no qual o mesmo preço é } \\
\text { cotado para todos os compradores independente de sua } \\
\text { localização. }\end{array}$ \\
\hline Descontos e concessões & $\begin{array}{l}\text { Desconto para pagamento à vista, desconto por } \\
\text { quantidade, descontos funcionais (oferecidos aos } \\
\text { membros do canal de distribuição), descontos sazonais } \\
\text { e concessões. }\end{array}$ \\
\hline Preço promocional & $\begin{array}{l}\text { Preço isca, preço de ocasião, cupons de desconto, } \\
\text { financiamento a juros baixos, maior prazo, garantia e } \\
\text { contratos de serviços, desconto psicológico (uso de } \\
\text { preço alto artificial para depois fazer uma redução } \\
\text { drástica). }\end{array}$ \\
\hline $\begin{array}{l}\text { Preço diferenciado } \\
\text { (Discriminado) }\end{array}$ & $\begin{array}{l}\text { Preço por segmento de consumidores, preço por } \\
\text { versão diferente de produto, preço de imagem, preço } \\
\text { por localização, preço por período. } \\
\text { Deve ser possível a segmentação, impossível } \\
\text { revender, deve ser legalizado e em consonância com } \\
\text { os consumidores, para que dê certo. Podem ocorrer } \\
\text { problemas. }\end{array}$ \\
\hline Preço de composto de produtos & $\begin{array}{l}\text { O produto faz parte de um composto, a empresa } \\
\text { procura um preço que maximize este composto: } \\
\text { 1. Preço de linha de Produtos: cada versão sucessiva } \\
\text { do produto traz características extras, permitindo } \\
\text { preços mais elevados. } \\
\text { 2. Preço de característica opcional: produtos opcionais } \\
\text { que acompanham o principal. } \\
\text { 3. Preço do produto cativo: fixação de preço baixo } \\
\text { para conquistar consumidor e ganho nos produtos } \\
\text { cativos. } \\
\text { 4. Preço Composto: uso de preço fixo mais variável. } \\
\text { 5. Preço de Subproduto: venda de subprodutos permite } \\
\text { a redução do preço do produto principal. } \\
\text { 6. Preço do Pacote: reunião de vários produtos são } \\
\text { vendidos mais baratos do que separadamente. }\end{array}$ \\
\hline
\end{tabular}

Fonte: Elaborado a partir de Kotler e Keller (2005) e Stanton; Waltker; Etzel (2001). 
A fixação de preços com descontos e abatimentos consiste em ajustar o preço básico para compensar certas situações relacionadas com o cliente ou com o mercado: o pagamento antecipado, a compra de um grande volume de produtos e as compras realizadas fora de temporada. As reduções nos preços são efetuadas por meio de desconto em dinheiro, de desconto por volume ou quantidade de compra, descontos funcionais, descontos sazonais e concessões ou abatimentos (TELLIS, 1995; SPROTT; MANNING; MIYAZAKI, 2003).

O desconto em dinheiro é uma dedução no preço para os compradores que pagam as contas na data determinada ou antecipadamente. Geralmente representa uma porcentagem do total cobrado na fatura. O desconto por quantidade é a redução do preço final para os clientes que compram grandes volumes de bens e os funcionais são oferecidos para os outros membros do canal de distribuição que concordarem em realizar serviços, como entrega ou estoque. Os descontos sazonais são concedidos àqueles que compram fora da estação e, por fim, as concessões são pagamentos efetuados para conseguir a participação em campanhas promocionais, apoio às vendas e outros programas especiais (KOTLER; KELLER, 2005; MANNING; MIYAZAKI, 2003).

$\mathrm{Na}$ determinação de preço promocional a companhia pratica preços mais baixos temporariamente, devido a diferentes circunstâncias como atrair os clientes para adquirir outros produtos, se desfazer de produtos sazonais e minimizar o volume de venda durante o ano (LAMBIN, 2000a; KOTLER; KELLER, 2005). Para enfrentar todas essas situações, as companhias podem utilizar diferentes técnicas, entre elas o preço 'isca', que consiste na redução do preço de marcas conhecidas para estimular um movimento maior nas lojas. É muito praticado pelos supermercadistas e pelas lojas de departamento, porém é um método que não tem a aprovação dos fabricantes, pois pode diluir a imagem da marca ou criar problemas com outros clientes que cumprem o preço estabelecido na tabela. 
Outra técnica conhecida é a utilização do preço de ocasião. São preços especiais em certas épocas do ano que servem para atrair mais clientes.

Os abatimentos em dinheiro são utilizados estimular a compra dos produtos dos fabricantes dentro de um período específico e podem ajudar a reduzir o estoque de mercadorias, sem diminuir o preço estabelecido na tabela.

O financiamento a juros baixos é uma técnica de preço promocional onde, em vez de cortar preços, a empresa oferece um financiamento com baixas taxas de juros e os prazos de pagamento mais longos são os financiamento a longo prazo, oferecidos, geralmente, pelas instituições financeiras (bancos) e concessionárias de automóveis. Ao utilizar a técnica de garantias e contratos de serviço, as empresas diminuem o preço em função dos serviços oferecidos e, finalmente, com os descontos psicológicos a empresa pode aumentar o preço, artificialmente, e depois oferecer um desconto substancial.

Para estabelecer o preço diferenciado (ou discriminatório), a empresa ajusta seus preços considerando as diferenças entre os clientes, os produtos, as localidades e o período. Portanto, os segmentos devem apresentar diferentes graus de demanda (LAMBIN, 2000a; KOTLER; KELLER, 2005). Os diversos métodos para determinar um preço diferenciado são: (i) o preço por segmento de clientes, onde tem-se preços diferentes de um mesmo produto, para diferentes grupos de clientes; (ii) o preço pela versão do produto, ou seja, são determinados preços diferentes por versões diferentes do produto, sem que estes sejam proporcionais aos seus custos de produção; (iii) o preço de imagem, que são preços diferentes para mesmo produto com base em diferenças de imagem; (iv) o preço por localização, que consiste em ter o mesmo produto com preços diferentes em locais diferentes e (v) o preço por período, que variam de acordo com a temporada, dia ou hora. 
$\mathrm{Na}$ estratégia de preço de composto de produtos, o apreçamento de um produto é influenciado pelos preços de outros produtos. A aplicação dessas estratégias apresenta algumas dificuldades, porque cada item possui custos diferentes, demandas diferentes e concorrência diferente. As empresas geralmente desenvolvem linhas de produtos, que apresentam uma variedade de atributos. $\mathrm{Na}$ fixação de preços de linha de produtos, deve-se determinar os patamares de preço estabelecidos para os vários itens do mix, considerando as diferenças de custos, o valor percebido pelo consumidor para cada um e os preços dos concorrentes.

Algumas empresas utilizam a fixação de preços de produtos opcionais, ou seja, o estabelecimento de preço de acessórios que são vendidos com o produto principal. Outras empresas fabricam produtos que somente podem ser utilizados com o produto principal, a fixação de preços de produtos cativos (KOTLER; KELLER, 2005; STANTON; WALTKER; ETZEL, 2001; LAMBIN, 2000a).

É importante observar que, após desenvolver a sua estratégia de apreçamento, a organização ainda está sujeita a enfrentar situações em que precisará mudar sua política. Uma redução de preços pode ser necessária devido à capacidade excedente da fábrica, ao declínio da participação de mercado, recessão econômica ou outros fatores discutidos, da mesma forma que um aumento pode ser necessário devido à inflação de custos ou ao excesso de demanda. O profissional de marketing deve, sempre, estar atento às reações da concorrência e preparar planos de ações com possíveis respostas a qualquer movimento dos competidores.

Até o presente tópico, o estudo abordou os procedimentos necessários para que uma empresa estabeleça de forma correta os preços de seus produtos ou serviços. A seguir, apresenta-se como essas etapas são definidas, especificamente, no varejo supermercadista. Alguns dos métodos utilizados possuem características distintas ou adaptações, por se tratar da 
comercialização de itens e não de sua produção, o que justifica a atenção especial dada ao setor.

\subsection{Gestão de Varejo Supermercadista}

Parente (2000), define o supermercado como o estabelecimento caracterizado pelo sistema de auto-serviço, com check-outs e produtos expostos de maneira acessível, que permitem aos consumidores se auto-servirem. Ampliando esta definição, Guimarães et alli. (2003), caracterizam os supermercados como estabelecimentos varejistas, nos quais se revende ampla variedade de produtos, utilizando-se do sistema de auto-serviço, no qual os clientes escolhem mercadorias expostas em gôndolas, displays, balcões e balcões refrigerados, sem a necessidade de vendedores, e realizam os pagamentos em check-outs, localizados na saída das lojas. Silveira e Lepsch (1997), afirmam que os principais benefícios desse sistema (autoserviço) para o supermercadista são: economia com mão-de-obra, economias de escala e baixos custos operacionais.

A empresa varejista é considerada por Coughlan et alli (2001), como um elo intermediário na cadeia produtiva, vendendo produtos manufaturados pelo setor industrial, situado a montante, para o consumidor final, situado a jusante, agregando-lhes valor por intermédio de serviços de distribuição. Lepsch (1996) acredita que, portanto, é razoável afirmar que o "produto" do varejo não é algo físico e sim os serviços ou atributos de uma loja, agregados a bens produzidos por outros setores da economia e prestados no comércio para o consumidor final. Entre os atributos apontados pelo autor estão: mix de preços, mix de produtos oferecidos, qualidade dos produtos, arquitetura do prédio, arquitetura ambiental e imagem da loja, layout, 
atendimento rápido e cortês, estacionamento, tamanho da loja, localização, cartão de crédito etc. Entretanto, autores como Levy e Weitz (2000), McGoldrick (1990) e Bloemer e Schroder (2002), afirmam que a imagem da loja é o posicionamento do supermercado formado pelas percepções dos consumidores, que resulta do conjunto destes atributos e, portanto, não pode ser considerada parte deles.

A imagem. Uma das primeiras definições de imagem de loja foi oferecida por Martineau em 1958, em seu clássico livro "The personality of the retail store" (McGOLDRICK, 1990), e enfatiza a necessidade de levar em consideração não apenas os fatores mais visíveis ou mensuráveis, mas também os fatores menos tangíveis, como a "personalidade" da loja. McGoldrick (1990), explica que a imagem da loja é o modo pelo qual a loja é definida na mente do comprador, parcialmente por suas qualidades funcionais e parcialmente por uma atmosfera de atributos psicológicos. Esta definição, porém, foi criticada por tender a atribuir um aspecto místico ao conceito, em que o consumidor não avalia racionalmente os atributos da loja.

Outros autores sugeriram que, ao invés de classificar a imagem como parte do comportamento de compra do consumidor sem uma base lógica seria razoável supor que o consumidor avalie racionalmente a loja por meio de uma função de utilidade de multi-atributos (McGOLDRICK, 1990). Esta definição foi abordada por Bloemer e Schroder (2002): a soma de todos os atributos da loja, da forma percebida pelo consumidor por meio de sua experiência com a loja.

Sheth, Mittal e Newman (2001) também definem imagem de loja como sendo a soma total das percepções que os clientes têm sobre uma loja. Tal percepção é determinada por fatores como: mercadorias, atendimento, preço, atmosfera, publicidade e funcionários. Para esses autores, a imagem da loja é que determina o tipo de cliente que será atraído e, por outro lado, esse mesmo cliente é quem vai "realimentar" essa imagem. 
Sobre aos componentes, muitos estudiosos classificam os fatores que compõem essa imagem de forma a relacionar aos elementos do composto de marketing do varejo. A importância relativa dos vários componentes varia consideravelmente, dependendo do mercado, setor, situação competitiva e segmentos de consumidores (McGOLDRICK, 1990). Existem razões lógicas pelas quais a importância relativa dos atributos deva variar entre mercados, considerando a comparação entre países, regiões, ou mesmo localidades diferentes.

Um componente ganha importância é a atmosfera da loja, ou seja, seu ambiente físico. Parente (2000) define atmosfera de loja como sendo o sentimento psicológico que o varejista desenvolve no consumidor quando este visita a loja, sendo também entendida como a personalidade da loja. Para desenvolver a atmosfera, os varejistas utilizam recursos que influenciam a visão, olfato e outros sentidos dos clientes. A atmosfera inclui iluminação, cores, música ambiente, limpeza, aroma, decoração e lay-out e que pode criar estímulo para o cliente permaneça na loja ou a vontade de sair rapidamente do local (SHETH; MITTAL; NEWMAN, 2001).

Porter e Claycomb (1997), explicam que uma tática que pode ser usada para favorecer a o varejista é a utilização de um mix de merchandising composto por um número significativo de marcas que possuem alta pontuação em uma pesquisa de awareness (lembrança de marca) e outras com imagem também forte. Para esses autores, a imagem da loja está diretamente relacionada à imagem de uma marca, pois marcas fortes e reconhecidas são sinônimos de qualidade e podem trazer o cliente de volta à mesma loja.

O sortimento das mercadorias também tem recebido bastante atenção por parte dos varejistas e uma estratégia de diferenciação cada vez mais utilizada é a inclusão de marcas próprias no conjunto de bens oferecido ao consumidor (COUGHLAN et alli, 2001). As marcas próprias auxiliam na construção da imagem da loja, pois permite ao varejista se diferenciar de 
concorrentes próximos e direcionar tráfego para dentro da loja. Como estão disponíveis apenas em uma cadeia específica de lojas, podem ser únicas em termos de valor e desempenho, e essa exclusividade pode ser considerada uma forma de se conquistar a lealdade de um cliente (SHETH; MITTAL; NEWMAN, 2001). Outros componentes são apresentados no quadro 6 .

Conforme explicado anteriormente, Levy e Weitz (2000) consideram o posicionamento um projeto e a implementação de um composto de varejo para criar uma imagem do varejista na mente do cliente em relação a seus concorrentes. Como ele enfatiza a imagem na mente do cliente (e não aquela na mente do gerente), devem ser feitas pesquisas para saber qual é a imagem do varejista e certificar-se de que ela esteja coerente com o que os clientes desejam nesse mercado-alvo.

O posicionamento do varejista é, provavelmente, mais importante para o sucesso do seu negócio do que as suas características reais (tangíveis). As redes varejistas tentam posicionarse de forma a criar uma imagem consistente com a auto-imagem do seu público. O projeto do ambiente de loja é um importante aspecto da estratégia de posicionamento de serviços, e influencia fortemente as impressões do consumidor e o comportamento tanto do cliente quanto do vendedor. $\mathrm{O}$ ambiente físico é particularmente importante na criação da impressão favorável para a loja de varejo, pois existem poucos critérios objetivos pelos quais os consumidores podem julgar a qualidade dos serviços que recebem (SCHIFFMAN; KANUK, 1997).

Estudo de Kim e Han (2000), demonstrou que as preferências dos consumidores por lojas específicas também podem estar ligadas às suas formações culturais, que estão relacionadas ao seu grupo étnico. Essas diferentes formações culturais levam os consumidores a possuírem diferentes interpretações das lojas e de seus produtos, devido às diferentes percepções dos 
atributos das lojas e às diferentes associações que esses consumidores fazem entre elas e as classes sócio-econômicas dos seus clientes. As classes sócio-econômicas estão significativamente relacionadas à imagem percebida da loja, o que permite aos varejistas a implementação de mensagens promocionais persuasivas direcionadas aos segmentos sociais alvejados.

Os componentes que formam a imagem da loja têm sido reconhecidos também, como um importante antecedente da satisfação e da lealdade (BLOEMER; SCHRODER, 2002). A lealdade à loja é construída por meio da satisfação e esta satisfação é construída, entre outras coisas, por meio da imagem da loja (BLOEMER; RUYTER, 1998). Para Levy e Weitz (2000), a satisfação com a loja é a avaliação pós-consumo de quanto a loja atendeu bem ou excedeu às expectativas do cliente.

Influenciados pelas mudanças rápidas no ambiente de varejo, pelos consumidores cada vez mais exigentes, pela competição mais acirrada, e pelas baixas taxas de crescimento dos mercados em geral, os varejistas estão, mais do que nunca, obrigados a instituírem de uma forma contínua o estabelecimento da satisfação com a loja e da lealdade à loja. Levy e Weitz (2000) afirmam que um varejista constrói a lealdade do cliente ao criar uma imagem clara e distinta de mix de varejo e ao reforçar de forma consistente essa imagem por meio de suas mercadorias e serviços. 
Quadro 6: Uma classificação dos componentes da imagem de loja

\begin{tabular}{|c|c|}
\hline Componente & Detalhamento \\
\hline Preço das mercadorias & $\begin{array}{l}\text { Preços baixos } \\
\text { Preços competitivos ou não competitivos }\end{array}$ \\
\hline Qualidade das mercadorias & $\begin{array}{l}\text { Boa ou má qualidade das mercadorias } \\
\text { Marcas em estoque }\end{array}$ \\
\hline Sortimento das mercadorias & $\begin{array}{l}\text { Amplitude e profundidade do sortimento } \\
\text { Possui ou não a marca que o cliente deseja } \\
\text { Possui ou não marcas elegantes }\end{array}$ \\
\hline Pessoal de vendas & $\begin{array}{l}\text { Postura do pessoal de vendas } \\
\text { Conhecimento do pessoal de vendas } \\
\text { Número de empregados da loja } \\
\text { Serviço bom ou ruim }\end{array}$ \\
\hline Conveniência de localização & $\begin{array}{l}\text { Localização perto da residência ou do trabalho } \\
\text { Acesso } \\
\text { Boa ou má localização }\end{array}$ \\
\hline Outros itens de conveniência & $\begin{array}{l}\text { Estacionamento } \\
\text { Horário de funcionamento da loja } \\
\text { Conveniência em relação a outras lojas } \\
\text { Lay-out da loja com relação à conveniência } \\
\text { Conveniência em geral }\end{array}$ \\
\hline Serviços & $\begin{array}{l}\text { Crédito } \\
\text { Entrega } \\
\text { Facilidade de devolução de mercadorias } \\
\text { Auto-serviço }\end{array}$ \\
\hline Promoções de vendas & $\begin{array}{l}\text { Vendas especiais } \\
\text { Cupons } \\
\text { Displays de loja } \\
\text { Símbolos e cores }\end{array}$ \\
\hline Propaganda & $\begin{array}{l}\text { Estilo e qualidade da propaganda } \\
\text { Mídia utilizada } \\
\text { Credibilidade da propaganda }\end{array}$ \\
\hline Atmosfera da loja & $\begin{array}{l}\text { Lay-out da loja não relacionado à conveniência } \\
\text { Decoração externa e interna da loja } \\
\text { Congestionamento dentro da loja } \\
\text { Prestígio da loja } \\
\text { Simpatia para com a loja }\end{array}$ \\
\hline Institucional & $\begin{array}{l}\text { Reputação e credibilidade da loja } \\
\text { Loja conservadora ou moderna }\end{array}$ \\
\hline Clientela da loja & $\begin{array}{l}\text { Nível sócio-econômico da clientela } \\
\text { Auto-imagem da clientela }\end{array}$ \\
\hline Aspectos físicos & $\begin{array}{l}\text { Instalações } \\
\text { Arquitetura da loja } \\
\text { Facilidade de compra }\end{array}$ \\
\hline Pós-venda & Satisfação ou insatisfação \\
\hline
\end{tabular}

Fonte: Adaptado de Kunkel e Berry (1968), Lindquist (1974), e Doyle e Fenwick (1974). 
O estudo de Bloemer e Schroder (2002) considerou a satisfação do consumidor como sendo um nível prazeroso de realização relacionado ao consumo. Para esses autores, a lealdade de loja pode ser definida como: a resposta comportamental enviesada (ou seja, não aleatória) expressa através do tempo, pelo consumidor com relação a uma loja, sendo uma função dos processos psicológicos (tomada de decisão e avaliação) resultante do comprometimento.

Essas respostas comportamentais foram consideradas, para Bloemer e Schroder (2002), como sendo: comunicação boca-a-boca, intenção de compra, e insensibilidade a preço.Bloemer e Schroder (2002) demonstraram que um consumidor que percebe uma loja em particular com imagem positiva está mais propenso a satisfazer-se com essa loja, do que um consumidor que percebe a loja com uma imagem menos positiva. Portanto, seu estudo concluiu que uma imagem de loja mais positiva levaria a um nível de satisfação maior. Além disso, uma imagem de loja positiva também levaria a um nível de afeto maior para com a loja, aumentando também o nível de satisfação. Por sua vez, a satisfação levaria à lealdade se a confiança e o comprometimento para com a loja estivessem presentes. Portanto, o modelo de inter-relação entre os conceitos acima pode ser apresentado conforme a figura 11.

Engel, Blackwell e Miniard (1995), explicam que as imagens formadas pelos consumidores, com base em suas percepções dos atributos considerados importantes, afetam o processo decisório de escolha da loja. A escolha da loja, para esses autores, seria uma função de características do consumidor e de características da loja. Para tomar a decisão sobre o local de compra, o consumidor busca informações que possam ajudá-lo a minimizar seu risco de insatisfação. 


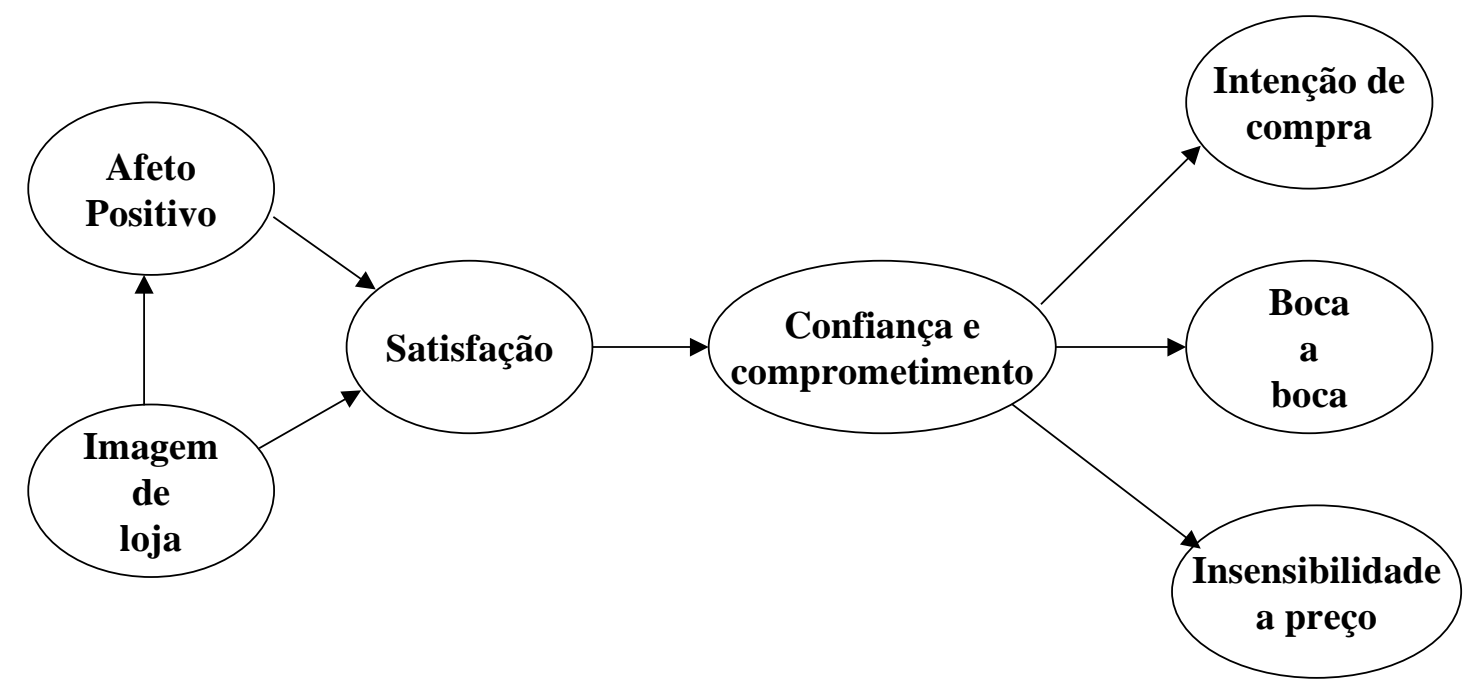

Fonte: Adaptado pelas autoras de Bloemer e Schroder (2002)

Figura 11. Modelo de satisfação e lealdade à loja.

Mason, Mayer e Ezell (1988), afirmam que estas informações podem ser fornecidas pelo próprio varejista por meio de propaganda e promoções. O consumidor ainda pode receber recomendações de seus vizinhos, parentes e amigos sobre em qual loja comprar. O varejista, de posse dessas informações, poderá explorar ao máximo seus instrumentos de marketing para criar o posicionamento desejado.

Engel, Blackwell e Miniard (1995) sugerem um modelo sobre o processo de escolha de loja que envolve os critérios de avaliação usados pelos consumidores e as características percebidas da loja, ou seja, a imagem da loja formada na mente do consumidor, conforme mostrado na Figura 12. Os consumidores de cada segmento formam imagens variadas de acordo com a sua percepção acerca dos atributos considerados importantes. Esta percepção e, portanto, a formação de imagem, depende das seguintes variáveis: localização, qualidade e natureza do sortimento, preço, propaganda e promoção, empregados, serviços oferecidos, atributos físicos da loja, tipo de clientela, atmosfera da loja e satisfação após a compra. 
Assim, verifica-se que o varejista possui várias ferramentas para conseguir a satisfação e a fidelidade de seus clientes, mas é preciso que ele as utilize adequadamente de modo que o consumidor consiga perceber e formar uma imagem positiva da loja, colocando-a como sua primeira opção de compra.

\section{Critérios Avaliatórios}

1. Localização

2. Amplitude e Profundidade de sortimento

3. Preço

4. Propaganda e promoção de vendas

5. Pessoal da loja

6. Serviços

7. Outros

\section{Características Percebidas das Lojas}

1. Localização

2. Sortimento

3. Preço

4. Propaganda e promoção de vendas

1. Pessoal da loja

2. Serviços

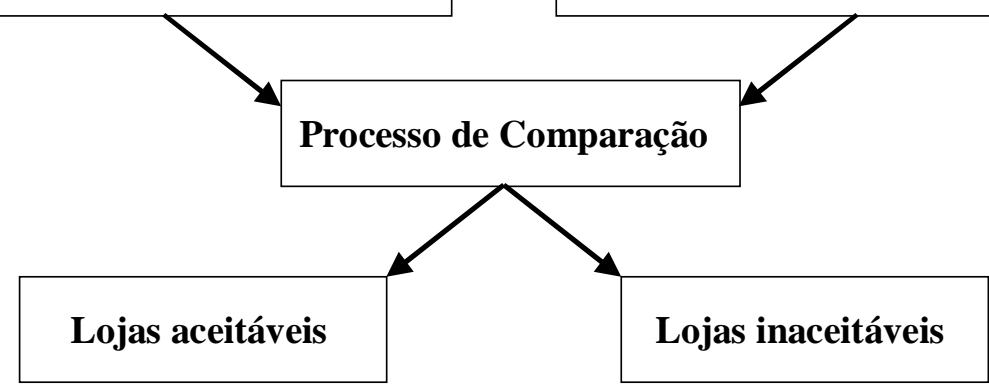

Fonte: Engel, Blackwell e Miniard (1995)

\section{Figura 12. Processo de seleção de loja.}

Lepsch (1996), considera o varejo também como uma unidade decisória da economia, considerada sob o prisma de transações com os fornecedores na compra e com os consumidores na venda de produtos. Tal dualidade, segundo o autor, faz com que ele integre o sistema de marketing dos fabricantes e, ao mesmo tempo, opere seu próprio sistema de marketing. 
Desde seu surgimento na década de 30 nos Estados Unidos, passando pela sua implantação na década de 50 no Brasil, até chegar no seu estágio atual, o supermercado evoluiu muito. Buscou maior eficiência, introduziu novas tecnologias redutoras de custos e preços e, assim, ocupou, gradativamente, o lugar das lojas especializadas tradicionais, no comércio varejista de alimentos e produtos de higiene e limpeza (SILVEIRA; LEPSCH, 1997). Com o acirramento da competição após o Plano Real e a abertura da economia a empresas e produtos estrangeiros, o consumidor tornou-se o foco das redes supermercadistas. Mais exigentes e com maior facilidade em memorizar os preços, o cliente fez com que o setor passasse a lutar pela sua preferência nas estratégias via preço e mais fortemente nas estratégias extrapreço.

As estratégias extrapreços foram discutidas nesse tópico. As estratégias via preço fazem parte do objetivo principal do estudo. O preço, como apresentado no quadro 6 é um dos componentes da gestão estratégica do varejo supermercadista e um dos critérios de maior importância na escolha da loja pelo consumidor, conforme visto na figura 12 .

Parente (2000), afirma que "de todas as variáveis do marketing mix, a decisão de preço é aquela que mais rapidamente afeta a competitividade, o volume de vendas, as margens e a lucratividade das empresas varejistas”. A afirmação volta à questão inicial da flexibilidade da variável preço em relação aos outros componentes do mix de marketing, ou seja, as políticas de preços dos varejistas podem ser alteradas em curtíssimo prazo e, devido à facilidade na implementação dessas alterações, muitos varejistas assumem uma postura fortemente competitiva, respondendo rapidamente às alterações de preço da concorrência. Boone e Kurtz (1998), argumentam que os preços desempenham um papel importante na percepção do varejista por parte do consumidor e são sempre um componente imprescindível para uma estratégia competitiva completa. 
O preço é um determinante da compra dos produtos pelos clientes. É um dos elementos chave para alcançar o volume de vendas desejado e tem grande impacto nos lucros das empresas e tem o papel fundamental na percepção da qualidade do produto pelos compradores. É também variável do composto que pode ser mais facilmente comparada pelo consumidor no momento da compra.

O próximo tópico discute a fixação de preços para o varejo supermercadista. Os passos propostos pelos autores apresentados na revisão bibliográfica sobre determinação de preços, são revistos agora com foco nas estratégias adotadas pelos supermercados. Alguns dos componentes que influenciam no posicionamento das lojas são discutidos em seguida como possíveis influenciadores no processo de precificação de produtos comercializados pelas grandes redes.

\subsection{Estratégias de Apreçamento nos Supermercados}

Lepsch (1966), afirma que pode-se esquematizar o apreçamento em um supermercado da seguinte maneira: primeiro, emprega-se o método de precificação do mark up, sendo que, o custo sobre o qual vai incidir a margem é custo da colocação do produto do fornecedor na loja. A seguir, os produtos do sortimento da loja são divididos em categorias e para cada uma é atribuída uma margem-objetivo. Por fim, o custo mais a margem dão um preço para cada um dos itens de uma categoria de produtos, que precisa ser comparado com o preço do mesmo item nas lojas da concorrência, localizadas dentro da área de influência do estabelecimento em foco. 
O autor destaca que não pode haver muita diferença entre os preços de um mesmo item dentro de uma mesma área de influência, principalmente para cima (preço mais alto). Neste caso, a empresa deve rever e ajustar o seu preço. A variação de preços pode aparecer por diferenças nos custos de produção dos comerciantes (REINGANUN,1979), na busca por preços menores por parte dos consumidores (ROB, 1985), ou pela lealdade, resultante das compras repetitivas de um único produto pelos clientes (MCMILLAN; MORGAN, 1988).

A tarefa de ajuste de preços é de responsabilidade do gerente da loja, que precisa manter as margens médias exigidas para as diversas categorias ou seções de sua loja e, principalmente, deve alcançar a margem média geral estabelecida pela rede de supermercados (LEPSCH, 1996). Silveira e Lepsch (1997), reforçam a responsabilidade do gerente na gestão do preço de sua loja, ao concluírem que houve descentralização na fixação de preços pelos supermercados adotando-se, na maioria dos casos, um sistema misto.

Os autores realizaram um estudo que confirmou a hipótese de que a autoridade da loja na precificação aumentou. Conseqüentemente, a responsabilidade da loja pela obtenção de resultados financeiros a ela designados, também aumentou. Cabe também ao gerente da loja, ficar atento ao comportamento do consumidor em relação aos preços dos produtos e ao sortimento, ao atendimento, aos serviços prestados, entre outros (SILVEIRA; LEPSCH, 1997).

Ao estabelecer o preço de venda ao consumidor, o varejista toma uma série de decisões estratégicas. Relacionando-se o estabelecimento do preço em redes supermercadistas (figura 13) com os seis passos propostos por Kotler e Keller (2005), para o apreçamento adequado de um produto pela indústria, e discutidos nos itens anteriores desta revisão bibliográficas, pode fazer a seguinte comparação: em relação aos objetivos de preços propostos, McGoldrick 
(1990), considera que os apresentados no quadro 7 são os adotados com mais freqüência pelas empresas varejistas.

\begin{tabular}{|c|c|c|c|c|}
\hline Preço Baixo & Custos & Precos dos & Percepcão & Preço Alto \\
\hline $\begin{array}{l}\text { Lucro } \\
\text { Impossível } \\
\text { Neste Preço }\end{array}$ & & $\begin{array}{c}\text { e dos } \\
\text { Substitutos }\end{array}$ & $\begin{array}{l}\text { Consumidores } \\
\text { de Oferta } \\
\text { Unica }\end{array}$ & $\begin{array}{c}\text { Demanda } \\
\text { Impossível } \\
\text { neste } \\
\text { Preço }\end{array}$ \\
\hline
\end{tabular}

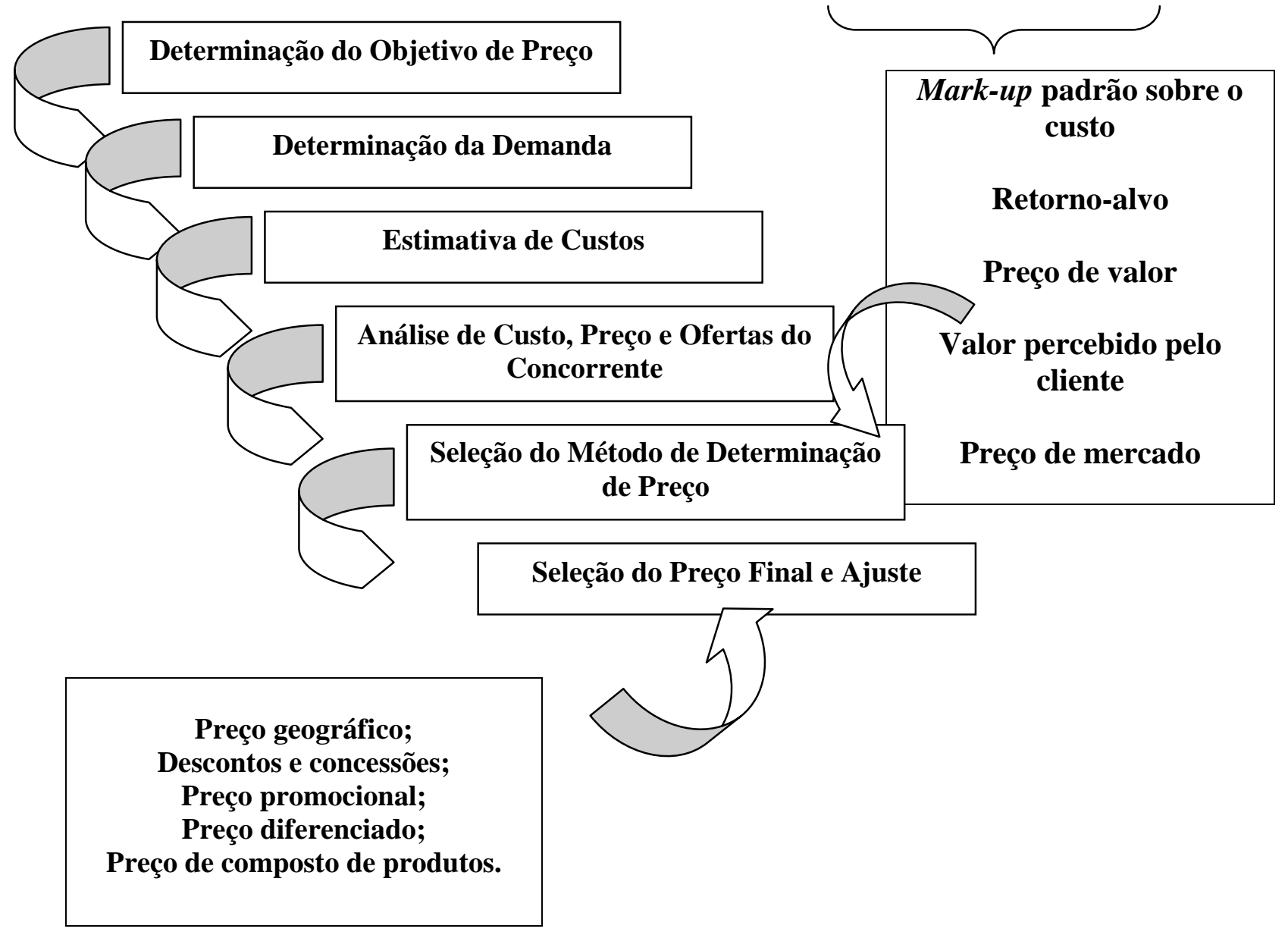

Fonte: Elaborado pela autora a partir de Kotler e Keller (2005).

Figura 13: Estabelecimento de Preço no Varejo 
Quadro 7: Objetivos de Preço Varejista

\begin{tabular}{|c|c|}
\hline Objetivo de Preço Varejista & Característica \\
\hline Maximização do lucro & $\begin{array}{l}\text { Redes de tamanho médio, com administração } \\
\text { familiar (geralmente). }\end{array}$ \\
\hline Retirada razoável & Redes pequenas, com administração familiar. \\
\hline Maximização da participação de mercado & $\begin{array}{l}\text { Característica das grandes e médias redes ou } \\
\text { ainda em cadeias que estão introduzindo } \\
\text { novos modelos ou outros novos formatos. }\end{array}$ \\
\hline Defesa do mercado & $\begin{array}{l}\text { Muitas redes varejistas procuram proteger } \\
\text { determinada área de influência criando } \\
\text { barreiras à entrada de novos concorrentes no } \\
\text { mercado. }\end{array}$ \\
\hline Estabilização do mercado & $\begin{array}{l}\text { Com esse objetivo, a loja procura } \\
\text { interromper a prática de guerra de preços } \\
\text { pela concorrência, podendo-se utilizar } \\
\text { também para desviar a atenção do } \\
\text { consumidor dos preços praticados. }\end{array}$ \\
\hline Imagem da rede & $\begin{array}{l}\text { A prática de uma política de preços baixos } \\
\text { todo dia (EDLP - every day low price) pode } \\
\text { ser um objetivo para atrair o consumidor e } \\
\text { mantê-lo fiel às lojas da rede. É possível } \\
\text { considerá-la também um objetivo que visa } \\
\text { mostrar ao consumidor integridade nos } \\
\text { preços. }\end{array}$ \\
\hline Preços abaixo do custo marginal & $\begin{array}{l}\text { Caso um item, categoria de produto ou seção, } \\
\text { apresentar sinais de entrada no estágio final } \\
\text { do ciclo de vida (declínio), um objetivo } \\
\text { comumente adotado é a eliminação dos } \\
\text { estoques por intermédio de preços baixos, de } \\
\text { maneira a gerar espaço para a entrada de } \\
\text { novos produtos. Utiliza-se também esse } \\
\text { recurso em uma promoção, como forma de } \\
\text { atrair clientes para a loja. }\end{array}$ \\
\hline
\end{tabular}

Fonte: Elaborado pela autora a partir de McGoldrick (1990) e Kotler e Keller, 2005. 
Parente (2000), completa, observando que o varejista pode buscar, como estratégias de apreçamento: (i) preços acima do mercado: o varejista não concorre em preço, evitando que a marcação de seus preços esteja baseada na concorrência; (ii) preços médios de mercado: os varejistas buscam a diferenciação em outros componentes do composto de marketing como localização, serviços ou linha de produtos e (iii) preços abaixo do mercado: varejistas que têm no preço sua arma competitiva mais forte, geralmente associado a uma estrutura de baixos custos com avançada tecnologia e modernos métodos de gestão.

Em termos de determinação da demanda, cada preço levará a um nível de demanda e terá um impacto diferente nos objetivos de marketing da empresa. Como foi discutido, demanda e preço são inversamente relacionados, ou seja, quanto mais alto o preço de um produto, menor a quantidade demandada por este mesmo item. A mesma regra é valida no supermercado. Por isso a preocupação com o controle de preços dos produtos ofertados.

Ghisi (2005), explica que a formação de oligopólios no setor supermercadista gera diversos riscos, como, por exemplo, a imposição de preços realizada pelas grandes redes junto aos fornecedores, que traz como conseqüência a restrição de opções para os consumidores. De acordo com esse boletim, a implantação dessas grandes lojas resulta na perda de um grande número de postos de trabalho. A abertura dessas empresas normalmente significa o aniquilamento dos pequenos supermercados, "mercadinhos", que operam no bairro e adjacências. Esse fato é crítico, pois os pequenos estabelecimentos são os responsáveis pela empregabilidade de boa parte da mão-de-obra no Brasil, tendo grande contribuição para o desenvolvimento social e econômico do país (GHISI, 2005). 
A oligopolização também aumenta o poder de barganha dos grandes grupos, que passam a competir por preço. Em contrapartida, os pequenos supermercadistas, que não têm escala comparável, acabam comprando produtos de atacadistas e não diretamente de fornecedores, aumentando, assim, os seus custos. Isso acarreta em produtos finais caros para o consumidor, pois a margem de lucro dos atacadistas é elevada, inviabilizando o repasse no preço das mercadorias (GHISI, 2005).

Quanto à estimativa dos custos, sabe-se que a demanda estabelece um teto no preço que uma empresa pode cobrar por seu produto e os seus custos determinam o piso, ou seja, o preço mínimo. A empresa varejista deseja cobrar um preço que cubra seu custo de produção, distribuição e venda do produto, incluindo um retorno justo por seu esforço e pelo seu risco. Especialistas concordam que a maioria das redes varejistas ainda utiliza o mark-up para calcular o preço das mercadorias com a taxa desejada de retorno.

A análise de custos, preços e ofertas dos concorrentes, também acontece da mesma forma para o varejista, ou seja, dentro da faixa de preços possíveis, determinados pela demanda de mercado e pelos custos da empresa, esta deverá levar em conta os custos, preços e possíveis reações de preços dos concorrentes. Vale considerar neste ponto, o conceito de shopping de preços, que é o nome dado à prática da obtenção de informações periódicas sobre preços praticados pelos concorrentes. Silveira e Lepsch (1997) explicam que, como a concorrência é determinada em cada mercado supermercadista, em geral cada loja possui sua própria equipe para coletar essas informações.

O shopping de preços abrange uma cesta básica ampliada, com cerca de 400 produtos, sendo estes de alto giro, marcas fortes e elevados gastos promocionais por parte dos fornecedores (alguns exemplos: sabão em pó Omo, leite condensado Moça, sal Cisne e Açúcar União). A cesta varia de acordo com o formato da loja, região do país, localização (ou área de 
influência), segmentação de mercado, entre outros (SILVEIRA; LEPSCH, 1997). Mas não é somente o shopping de preços que possui informações importantes sobre a concorrência. Os supermercadistas recorrem também a dados adicionais em jornais, tablóides e televisão para formarem os preços de seus produtos (SILVEIRA; LEPSCH, 1997).

Em relação à seleção de um método de determinação de preços, para os varejistas também são considerados parâmetros como os custos, a concorrência, a avaliação dos clientes e o preço máximo a ser cobrado. Os métodos mais utilizados no varejo encontram-se descritos no quadro 8 .

Sobre as margens, Boone e Kurtz (1998), ainda ressaltam que constituem fatores importantes na imagem do varejista perante seus atuais e possíveis clientes, afetando ainda a sua capacidade de atrair clientes. Margens muito altas podem assustar e afastar os consumidores e a prática de uma taxa inadequada (muito baixa) pode não cobrir os custos e não gerar retorno. As margens são expressas como porcentagem do preço final de venda de um produto ou do seu custo (BOONE; KURTZ, 1998). Suas fórmulas são:

Percentual de Margem sobre o Preço de Venda = Valor Acrescido ao Custo (Margem) Preço de Venda

Percentual de Margem sobre o Custo $=\underline{\text { Valor Acrescido ao Custo }(\text { Margem })}$

Custo 
Quadro 8: Métodos de Determinação de Preços utilizados por Varejistas

\begin{tabular}{|c|c|}
\hline Objetivo de Preço Varejista & Característica \\
\hline Mark-up padrão sobre o custo & $\begin{array}{l}\text { Muitos varejistas adotam esse método por ser } \\
\text { mais rápido, mecânico e relativamente simples de } \\
\text { ser usado. Resulta sempre de dois fatores: os } \\
\text { serviços oferecidos (custos que precisam ser } \\
\text { cobertos) e taxa de giro de estoque. }\end{array}$ \\
\hline Retorno-alvo & $\begin{array}{l}\text { Preço que permite atingir a taxa-alvo de retorno - } \\
\text { ROI (return over investment). }\end{array}$ \\
\hline Preço de valor & $\begin{array}{l}\text { Preço baixo para oferta de alta qualidade - no } \\
\text { varejo, o preço de valor traduz-se na política de } \\
\text { fixar preços baixos todos os dias (EDLP) - o } \\
\text { varejista que seguir a prática cobra um preço } \\
\text { baixo constantemente, todos os dias, sem } \\
\text { descontos temporários nos preços, eliminando } \\
\text { assim, a incerteza de preços de uma semana para } \\
\text { a outra; }\end{array}$ \\
\hline Valor percebido pelo cliente & $\begin{array}{l}\text { Considera as percepções dos clientes e não os } \\
\text { custos do vendedor como chave para determinar } \\
\text { preço. Como analogia no varejo, tem-se a } \\
\text { estratégia de preço alto-baixo (High Low Price - } \\
\text { HILO), onde o varejista cobra preços mais altos, } \\
\text { mas realiza promoções freqüentes, nas quais os } \\
\text { preços caem temporariamente abaixo do nível da } \\
\text { política EDLP. As promoções criam entusiasmo } \\
\text { e atraem compradores. Por esse motivo, a EDLP } \\
\text { não constitui garantia de sucesso. Muitos } \\
\text { varejistas utilizam uma combinação de } \\
\text { estratégias de determinação de preços alto-baixos } \\
\text { e de preços baixos todos os dias, com um } \\
\text { aumento de propaganda e de promoções. }\end{array}$ \\
\hline Preço de mercado & $\begin{array}{l}\text { Estabelecer preços com base nos concorrentes. } \\
\text { Prática comum entre varejistas, com } \\
\text { conhecimento entre os competidores para } \\
\text { realização de shopping de preços em suas lojas. }\end{array}$ \\
\hline
\end{tabular}

Fonte: Elaborado pela autora com base em Boone e Kurtz (1998), Levy e Weitz (2000), Parente (2000). 
Porém, quando se conhece apenas o custo e o percentual de margem calculado sobre o preço de venda, as seguintes fórmulas são utilizadas:
Preço $=$
Custo
$100 \%$ - Percentual de Margem sobre o Preço de Venda
Preço $=$
Percentual de Margem sobre o Custo $100 \%+$ Percentual de Margem sobre o Custo
Preço $=$
Percentual de Margem sobre o Preço de Venda. 100\% - Percentual de Margem sobre o Preço de Venda

Boone e Kurtz (1998) explicam que as margens baseiam-se, em parte, no julgamento do comerciante com relação aos preços que os consumidores estariam dispostos a pagar por um produto. Quando estes se recusam a pagar o preço fixado ou surgem produtos de melhor qualidade o varejista trabalha com a estratégia de desconto, que tem o seu percentual calculado pela fórmula:

Percentual de Desconto $=\frac{\text { Valor do Desconto }}{\text { Novo Preço }}$ 
Os descontos também podem ser utilizados para avaliações (BOONE; KURTZ, 1998). Os gerentes da loja ou os compradores podem ser avaliados, em parte, com base nos percentuais médios de descontos concedidos nas linhas de produtos pelas quais são responsáveis dentro de uma rede supermercadista.

Por fim, a seleção do preço final, compreendida como o ajuste do preço em função da percepção de qualidade - por parte dos consumidores - e da influência de outros elementos do composto de marketing, levando em consideração questões como serviços prestados, localização e outros. As táticas não são mutuamente exclusivas e podem ser utilizadas simultaneamente.

Um problema que pode ser encontrado ao estabelecer uma estrutura de preços diz respeito a produtos que fazem parte de um mix ou linha. Neste caso não são apenas os preços que variam, mas também os produtos considerados. Desta forma, a fixação de preços não deve seguir a mesma lógica determinada para um único item. $\mathrm{O}$ varejista busca, neste caso, um conjunto de preços que maximize o lucro total (GRACIOSO, 1997).

A determinação de preços é difícil porque os produtos possuem custo e demanda interrelacionados e estão sujeitos a diferentes graus de concorrência. Toledo, Proença e Mello Jr (2003), afirmam que esse problema abre espaço para a aplicação de técnicas mais modernas de gestão no varejo, como o gerenciamento de categorias. Os autores explicam que o gerenciamento de categorias é uma das ferramentas do sistema Resposta Eficiente ao Consumidor - ECR (Efficient Consumer Response) que tem por objetivo definir o sortimento, os preços, as ofertas e promoções para atender os diferentes públicos de consumidores e obter uma coerência no modo de apresentação dos produtos no ponto de venda por afinidade de consumo, o que facilita a venda o cliente e gera aumento de vendas. 
O ECR Brasil caracteriza uma estrutura de categoria como sendo um mapa da "árvore de decisão do consumidor" (ECR Brasil, 1998). A questão chave é a capacidade de refletir o modo como o consumidor toma sua decisão quando faz uma compra dentro da categoria. "Nesse processo, a atribuição de papéis para as categorias é uma das mais importantes decisões a serem tomadas pelo varejista, pois fornece a base para a diferenciação competitiva e conseqüente alocação de recursos entre as unidades estratégicas de negócio, por categoria do varejista" (TOLEDO; PROENÇA; MELLO JR, 2003). A classificação é a seguinte:

- Dominantes "Destino": são famílias de produtos que possuem como característica uma grande variedade de produtos igual ou superior à média do mercado, sendo que o varejista busca uma notoriedade e reconhecimento por parte dos seus clientes, no sentido de que sua oferta de variedade de produtos seja a melhor do mercado. Os produtos dessa categoria têm a característica ímpar de atrair os consumidores às lojas. Exemplo: mercearia seca (açúcar, arroz, feijão etc);

- Competitivas "Tráfego": são famílias de produtos que possuem como característica uma variedade de produtos igual à média do mercado, sendo que o varejista posicionase "corretamente" no que tange a oferta de variedade de produtos. Essas famílias são compostas de produtos que também têm característica de atrair os consumidores às lojas em razão da necessidade e periodicidade de compras. Exemplo: leite longa vida, suco e pão de forma;

- Convenientes "Bandeira": são famílias que apresentam como característica uma variedade de produtos limitada, ou seja, igual à oferta dos demais concorrentes do mesmo segmento, porém inferior à variedade ofertada pelos varejistas especialistas. Exemplo: tintas, ferramentas, automotivos; 
- Sazonais: são famílias que possuem como característica uma variedade de produtos grande, em razão única e exclusiva de ocorrência de um evento sazonal. Exemplo: chocolates, panetones, perus.

Toledo, Proença e Mello Jr (2003), consideram ainda que o papel da categoria freqüentemente fornece diretrizes para a alocação de recursos do varejista, desde estoques, espaço nas prateleiras e investimentos promocionais/publicitários a gastos de capital e tempos de gerenciamento. Por exemplo, categorias com papel "destino" podem ter preços mais competitivos, com o objetivo de atrair os consumidores e tornar a loja preferida nas compras da categoria. Nas demais, os preços podem ser menos competitivos.

Apesar de todos os seis passos estarem adequados à escolha da estratégia de apreçamento dos produtos comercializados pelo varejo supermercadista, é importante lembrar que muitas das suas atividades são completamente distintas das atividades de uma indústria. O supermercado, responsável pela entrega do produto ao consumidor final, oferece vários serviços que não são comuns aos fabricantes. Muitas dessas ações podem ter grande influência sobre a fixação de preço dos bens comercializados, sejam por aumentar os custos ou mesmo por oferecer maior valor para o cliente.

A próxima discussão refere-se a algumas variáveis que possivelmente interferem na decisão de apreçamento dos supermercadistas sobre os itens que disponibilizam para os seus consumidores. Tais variáveis vão além da demanda ou custo dos produtos e representam questões fundamentais para ganho de competitividade no varejo. 


\subsection{Variáveis Qualitativas que Influenciam no Apreçamento dos Produtos no Varejo}

Beisel (1993) apud Vance e Angelo (2003), sugere que a definição do nível de preços mais adequado seja efetuada a partir da análise das características de diferentes dimensões do composto de varejo (quadro 9). Em um primeiro momento, é essencial que o varejista defina quem é o seu público alvo.

\section{Quadro 9: Características que influenciam os níveis de preços no varejo}

\begin{tabular}{|c|c|c|c|}
\hline \multirow{2}{*}{ Características } & \multicolumn{3}{|c|}{ Estratégias de Preços } \\
\hline & Abaixo do Mercado & Nível do Mercado & Acima do Mercado \\
\hline Localização & Inconveniente & Competitiva & Privilegiada \\
\hline $\begin{array}{c}\text { Horário de } \\
\text { Funcionamento }\end{array}$ & Curto & Competitivo & Longo \\
\hline Serviço & Pouco/nenhum & Médio & Personalizado \\
\hline Prestígio & Pouco & Médio & Alto \\
\hline $\begin{array}{c}\text { Exclusividade do } \\
\text { Produto }\end{array}$ & Nenhuma & Média & Excluxivo \\
\hline $\begin{array}{c}\text { Merchandising } \\
\text { Fashionableness }\end{array}$ & Baixo & Média & Alto \\
\hline Custo da Mercadoria & Baixo & Médio & Alto \\
\hline
\end{tabular}

Fonte: Vance e Ângelo (2003).

A seguir, é preciso que identifique e analise as características do seu negócio. Localização, horário de funcionamento, serviços, prestígio, a exclusividade do produto/mercadoria, merchandising fashionableness, que pode ser compreendido como o grau de requinte ou elegância dos produtos comercializados e custo das mercadorias são os principais aspectos sugeridos para avaliação, segundo o autor. 
Enquanto as características do produto podem ser as mesmas entre os diferentes equipamentos varejistas, a variabilidade na qualidade de serviço e as características do mercado podem ser diferentes dentro de cada equipamento varejista (ANCARANI; SHANKAR, 2004).

Além das variáveis destacadas por Vance e Ângelo (2003), Lepsch (1996) e Ancarani e Shankar (2004), o presente estudo observará outros fatores colocados como importantes por estudiosos de varejo como influenciadores da fixação de preços nos supermercados.

\subsubsection{Produto}

Para Czinkota (2001), os produtos são o conjunto de atributos, funções e benefícios que os clientes compram. O termo "produto" significa a oferta de uma empresa capaz de satisfazer uma necessidade do consumidor (KOTLER; KELLER, 2005). Além disso, os produtos de consumo podem ser divididos nas seguintes categorias: (i) produtos de conveniência: itens baratos que os consumidores compram com pouco esforço e são amplamente distribuídos, (ii) produtos de compra comparada: mais caros que os de conveniência e a decisão de compra é mais importante, (iii) produtos de especialidade: os consumidores desejam uma marca particular, (iv) produtos substitutos: não são opções, sendo a distribuição muito limitada e, (v) produtos não procurados: são desconhecidos ou não, mas não são ativamente procurados, até que necessite deles, sendo as vendas personalizadas.

Conforme observado, nas diferentes classificações de produtos, suas características influenciam no preço para o consumidor final. Produtos de conveniência são considerados mais baratos, enquanto produtos de especialidades, como são procurados por marcas específicas, tendem a serem mais caros. 
Nagle e Holden (1995), consideram que a administração do produto é a mais poderosa ferramenta de influência dos preços. O produto pode influenciar o preço, dependendo do nível de diferenciação do produto, do seu estágio no ciclo de vida e do segmento de mercado de atuação (ZICKER, 2002), Nos estágios de introdução e crescimento o preço é mais alto e na maturidade a tendência é de queda dos preços (KOTLER; KELLER 2005). Porém, é possível modificar o produto ou aumentar o período de estágio, analisando e percebendo as mudanças no ambiente.

Stanton, Walker, Etzel, (2001) consideram um mix de produtos como o conjunto de todos os produtos oferecidos para venda por uma empresa. Uma linha de produtos é um amplo grupo de produtos, destinados a usos essencialmente similares e tendo características físicas similares. O mix de produtos é composto por uma ou mais linhas de produtos. Todos os produtos que uma empresa comercializa podem ser considerados o seu o mix. A amplitude, ou abrangência, do seu composto é a série de diferentes linhas de produtos, a extensão é o número de produtos (diferentes marcas) dentro de uma linha e a profundidade da linha são os tipos de produtos dentro de cada marca (STANTON, WALKER e ETZEL, 2001; KOTLER; KELLER, 2005; PARENTE, 2000).

\subsubsection{Marca}

Com relação às marcas dos produtos, estudiosas afirmam que marcas e criação de marcas são ingredientes vitais, necessários ao sucesso no mercado (SHULTZ e BARNES, 2001). Os consumidores utilizam-se das marcas como fontes de informação, simplificando escolhas e 
reduzindo riscos da aquisição. Elas capturam crenças sobre os atributos e a imagem geral do produto entre os clientes. Os fabricantes estão cada vez mais interessados em comercializar novos produtos sob a proteção de nomes de marca bem estabelecidos, familiares aos clientes, aumentando sua aceitabilidade (IACOBUCCI, 2001).

A American Marketing Association (AMA) define marca como um nome, termo, símbolo/signo, ou uma combinação de todos, que está associado a diferentes produtos ou serviços de uma empresa em particular. Essencialmente, uma marca significa a promessa de entrega de um produto ou um "pacote" particular de características, benefícios e serviços para os consumidores. Iacobucci (2001), considera que as marcas possibilitam aos consumidores a associação a funcionalidades, imagens e experiências. Com um mercado competitivo, os produtos ficam mais uniformes e com isso as marcas evoluem para oferecer um valor diferenciado aos seus clientes. A marca tornou-se base imediata para a escolha de uma mercadoria, traduzindo-se em lucros para a empresa.

O sucesso da marca depende de associações. A marca está associada a uma rede de pensamentos ou associações feitas apenas nas cabeças dos consumidores. O grande desafio para uma marca é desenvolver um arranjo de idéias associadas ao seu símbolo, não sendo apenas um nome, mas um conjunto de significados. A construção de uma marca é orientada por uma visão de posicionamento desejado e implementada pelas decisões relacionadas ao composto de marketing.

O valor da marca apoiá-se na idéia de que os consumidores compram e usam certos produtos com marcas, mais pelo que eles representam do que pelo que eles realmente fazem. Aaker (1991) define valor de marca como sendo o conjunto de ativos e passivos relacionados a uma marca, seu nome e símbolo, que adicionam ou subtraem valor ao valor provido pelo produto ou serviço. $\mathrm{O}$ autor identifica quatro principais categorias pelas quais o valor da marca pode 
ser deduzido: reconhecimento de marca, associação de marca, qualidade percebida e fidelidade à marca. Essas categorias são estreitamente relacionadas, assim, a lealdade da marca é dependente do seu reconhecimento pelos consumidores, do poder de estabelecimento de associações, bem como do nível de qualidade percebida.

Aaker (1996), afirma que o desafio para as marcas é que elas possuam uma imagem clara e distinta, que importe para o consumidor e realmente as diferencie dos outros concorrentes. Para a construção de grandes marcas, o autor sugere que a empresa encare suas marcas não somente como um produto ou serviço, mas como uma organização, uma pessoa e um símbolo. Assim, tornar prioridade inovação, liderança de mercado ou qualidade de produto como estratégia empresarial tem impacto direto na percepção da marca se esse também for seu posicionamento. Esse tipo de associação com a organização é mais difícil de imitar do que atributos de produtos.

As marcas são selecionadas e usadas pelos consumidores para dizer alguma coisa que eles gostariam de dizer. O comprometimento com uma marca pode ser definido como um elo com essa marca particular dentro de uma categoria de produto.

\subsubsection{Formato dos Canais de Distribuição}

Neves (1999), afirma que os canais de distribuição podem ser entendidos como sendo o percurso que o produto faz até o consumidor final. Um conjunto de organizações interdependentes envolvidas no processo de disponibilizar esse produto ou serviço para uso ou consumo ou ainda como maneiras de desenhar, desenvolver e manter relacionamentos 
entre os participantes do canal, de tal forma a obter vantagens competitivas sustentáveis pelas empresas, tanto em nível individual como coletivo (COUGHLAN et alli, 2002). Para Rosenbloom (1999), podem ser entendidos como uma organização externa que a gestão utiliza para atingir os seus objetivos de distribuição. A organização é externa porque não faz parte da estrutura interna da empresa, são os intermediários entre a indústria e o consumidor final.

Os intermediários tomam muitas formas atualmente, incluindo lojas de departamentos, lojas de descontos, lojas de eletrodomésticos e eletrônicos, lojas de vestuários, hipermercados, supermercados, lojas especializadas, lojas de conveniência, franquias, clubes de compras, e varejistas on-line. Além disso, os varejistas podem ocupar-se de bens com marca própria (marca de loja) e podem também se integrar verticalmente para trás de forma eficaz na cadeia de suprimento (COUGHLAN et alli, 2002).

No Brasil, os tipos mais importantes de varejista alimentício para distribuição são hipermercados, supermercados, lojas de conveniência, lojas de especialidades (açougues, varejões, padarias, entre outros), mercearias e outros formatos (PARENTE, 2000). Muitas redes supermercadistas engajaram no processo de reformulação do padrão de suas lojas, para atender a diversos segmentos de mercado, passando a operar com diferentes bandeiras, cada uma focada em um nicho de mercado atrativo (GHISI, 2005).

Os critérios da AcNielsen (2004), classificam os canais de distribuição de produtos alimentares em 03 categorias básicas. Cada categoria possui um grupo de diferentes formatos. As categorias são: (i) consumo local formada por bares, restaurantes, lanchonetes e adegas; (ii) auto-serviço que se refere ao formato de varejo alimentício caracterizado pela disposição dos produtos em self-service e pela existência de caixas (check-outs) na saída como os supermercado e hipermercados e (iii) tradicionais, no qual pressupõem-se a presença de 
atendente (vendedor ou balconista), que assiste e interage no processo de compra (compra assistida), como armazéns, empórios, mercearias, padarias etc.

No auto serviço, as classificações da AcNielsen (2004) e da ABRAS (2005), consideram como supermercados os estabelecimentos encontrados em bairros ou vizinhança, para compras rotineiras, preços médios, que apresentam, como principais seções de vendas, mercearia, bazar e perecíveis. Possuem cerca de 1.500 a 5.000 itens em exposição e de 2 a 40 check-outs, mais de $300 \mathrm{~m}^{2}$ de áreas de vendas e faturamento anual de mais de 1 milhão de dólares. Em termos do porte da loja, são considerados pequenos aqueles supermercados que possuem até 4 check-outs; de pequenos à médios, os com 5 a 9 check-outs; médios, quando possuem de 10 a 19 check-outs e grandes os supermercados, cujo número de check-outs varia entre 20 a 49.

Os hipermercados são estabelecimento localizado em áreas de intenso fluxo e fácil acesso, destinado às compras de maior volume, preços baixos e com mais descontos. Possuem como principais seções de vendas, mercearia, bazar e perecíveis, têxteis e eletrodomésticos. Têm mais de 5.000 itens em exposição, número de check-outs acima de 50 mais, $5.000 \mathrm{~m}^{2}$ de áreas de vendas e faturamento anual de mais de 12 milhões de dólares. A tabela 1 apresenta a classificação do setor supermercadista de acordo com o número de check-outs.

Ghisi (2005), apresenta os principais formatos de loja existentes como:

1. Loja de conveniência: modelo importado dos Estados Unidos na década de 80, que pode ser caracterizado por oferecer pequena variedade de itens (cerca de 1000 itens), principalmente de conveniência, e possuir área de venda de $50 \mathrm{~m}^{2}$ a $250 \mathrm{~m}^{2}$. São lojas relativamente pequenas, de fácil acesso e para compras rápidas, que funcionam 24 horas por dia. Constituem um importante canal de distribuição varejista, minimizando 
esforços de compra dos clientes. Essas lojas estão localizadas em postos de gasolina ou em áreas de grande concentração populacional. Os preços praticados geralmente são $15 \%$ maiores do que os dos supermercados convencionais.

2. Loja de Sortimento Limitado ou discount: conceito trazido da Alemanha que representou, na época, uma inovação incremental. Opera cerca de 700 itens, basicamente de mercearia e praticamente nenhum serviço. Na década de 80 , as lojas de sortimento limitado se tornaram muito populares, impulsionadas pela rede Minibox, do Pão de Açúcar, que passou a ser seguida por concorrentes da época. Esse formato de loja praticamente desapareceu na década de 90 e retomou sua importância a partir do ano 2000. As lojas de descontos atingem públicos mais específicos, de baixa renda, e têm raio de cobertura reduzido. Esse tipo de loja opera com sortimento limitado e poucos funcionários, o que pode resultar na oferta de preços competitivos.

3. Supermercado Compacto: supermercado de menor porte é o conhecido "supermercado de vizinhança". Representam a maioria das unidades de auto-serviços do Brasil e, em geral, pertencem a operadores independentes. Atualmente, são responsáveis por cerca de $14 \%$ da distribuição de alimentos no Brasil, onde estão em plena ascensão.

4. Supermercado Convencional: tradicional supermercado, com área de venda de $700 \mathrm{~m}^{2}$ a $2.500 \mathrm{~m}^{2}$. Dentre as seções existentes, opera principalmente as mais tradicionais: mercearia, perecíveis, bazar, carnes e aves, frios e laticínios, sendo crescente o aumento de seções, para atrair o cliente, como a de padaria e de peixaria. A média de itens ofertados é de 9.000 e os produtos são alimentícios, na grande maioria. Pode ser definido como um mercado generalista, que revende para o consumidor final ampla variedade de produtos de forma departamentalizada, no sistema de auto-serviço. A maioria das redes atuantes no Brasil opera grande número de lojas classificadas como supermercados convencionais. 
5. Superloja: tipo de loja que opera com uma completa linha de produtos alimentícios. Os não-alimentícios começam a crescer em importância, podendo representar até $10 \%$ das vendas. A área de comercialização possui $4.500 \mathrm{~m}^{2}$, em média, e a ênfase é nos serviços não perecíveis, bem como em uma ampla seção de alimentos. A Superloja também oferece uma razoável gama de produtos têxteis e eletrônicos. O número de itens pode ser até $60 \%$ superior ao de um supermercado convencional e operam um número médio de 14.000 itens de produtos. No Brasil, existem cerca de 400 superlojas de alimentos, as que representam $13 \%$ das vendas do varejo alimentício. A tendência é que esse tipo de formato ganhe importância nos próximos anos.

6. Hipermercado: o conhecido modelo de loja importado da França, caracterizado pelo largo espectro de produtos alimentares e bebidas. A área para alimentos geralmente é maior do que $50 \%$ do total da área de vendas totais da loja. Os hipermercados trabalham com completa linha de alimentação e quase completa linha de nãoalimentos, vendendo cerca de 35.000 itens. São comercializados em torno de 45.000 itens e as seções típicas dessas lojas são: mercearia, hortifrutigranjeiros, carnes e aves, padaria, frios e laticínios, bazar, peixaria, têxtil e eletrônicos. No Brasil existem mais de 100 hipermercados, que representam $13 \%$ das vendas do varejo alimentar.

7. Supercenter: esse tipo de formato é considerado uma adaptação norte-americana dos hipermercados franceses e tem as características de uma loja de departamento acrescida de um supermercado, que ocupa $40 \%$ da área de venda. Chega a operar em torno de 60.000 itens e tem dimensões de até $19.000 \mathrm{~m}^{2}$. O layout de disposição das gôndolas cria seções isoladas dentro da loja.

8. Loja-Depósito: no Brasil, o número de lojas-depósito ainda é muito pequeno, sendo composto pelas redes que oferecem mais de 7.000 itens, com boa participação dos perecíveis. A área de venda geralmente é em torno de $4.000 \mathrm{~m}^{2}$ a $7.000 \mathrm{~m}^{2}$. Opera as 
seguintes seções: mercearia, hortifrutigranjeiros, carnes e aves, têxtil, frios e laticínios, bazar e eletrônicos. O foco desse tipo de loja está relacionado à imagem de preço baixo e aos poucos serviços oferecidos. A oferta de não-alimentos começa a crescer nesse formato, e as vendas desses produtos atingem $8 \%$ do total vendido.

9. Clube de Atacadistas: tipo de loja que opera nas linhas alimentícia e não-alimentícia, tem área de vendas despojada e de baixo investimento, expondo a mercadoria em estruturas metálicas. O público alvo desse tipo de loja pode ser definido pelos pequenos comércios, bares e restaurantes, bem como por famílias de menor poder aquisitivo. Geralmente essas lojas operam 5000 itens de produtos e a porcentagem de vendas dos não-alimentos chega a 35\%. Operam nas seções de mercearia, bazar, carnes e aves, vestuário, frios e laticínios e eletrônicos. O número de check-outs existentes nessas lojas fica entre 25 a 35 .

Entretanto, Stern, El-Ansary e Coughlan (1996), consideram que as atividades varejistas podem ser feitas por todos os membros do canal, e até mesmo pela indústria e observa-se grande competição dentro dos diferentes formatos. Além disso, a maneira como o produto é distribuído também é importante para a formação do preço. Dependendo do canal, é possível definir preços diferenciados por segmento. Deve-se ter o cuidado de escolher corretamente o canal de distribuição, porque ele pode guiar toda a política de preços dentro da cadeia de suprimentos, caso os intermediários tiverem um alto poder de negociação.

Nagle e Holden (1995), recomendam uma estratégia de distribuição coerente com a estratégia de preços, ou seja, para um produto que atrai os compradores pelo baixo preço é necessário obter baixo custo de distribuição, já para um produto que atrai os consumidores pelos seus atributos superiores apesar do preço alto, é recomendável obter uma distribuição que complemente esses atributos e os torne visíveis. 
Quando o valor da diferenciação do produto se suporta por meio desta argumentação, é arriscado confiar completamente na distribuição independente. A distribuição pode-se transformar em um serviço de diferenciação do produto, diminuindo a sensibilidade a preços, por parte dos clientes. Portanto, na medida em que for oferecido um pacote de serviços diferenciados pela distribuição, aumenta-se a competitividade do produto, tornando-se o preço menos relevante.

\subsubsection{Localização da Loja}

"Os supermercadistas, ao fixar seus preços, levam em conta os preços praticados pela concorrência. São consideradas concorrentes as lojas que se situam numa mesma área geográfica de influência” (SILVEIRA, LEPSCH, 1997). O número de lojas concorrentes na mesma localização determina a estrutura do mercado, o que permite concluir que o poder de monopólio no setor supermercadista varia segundo o grau de concorrência existente nos diferentes mercados.

Lukianocenko (2003), afirma que um dos fotos que mais chamou a atenção em um estudo realizado pela LatinPanel, relaciona-se aos motivos que levam o consumidor a escolher um supermercado para realizar suas compras. Entre esses motivos, destaca-se a proximidade do estabelecimento com a casa ou trabalho do consumidor, que aparece em primeiro lugar, em todas as classes analisadas (A até E), em $52 \%$ dos casos. O estudo também enfatiza que a proximidade tem o mesmo peso, tanto para clientes de pequenos estabelecimentos quanto para os de grandes lojas (LUKIANOCENKO, 2003). A informação reforça o conceito de que a conveniência é um fator primordial na definição da opção de compra, sendo um forte 
indicativo a favor do supermercadista de pequeno porte. Se ele conhece as características de sua vizinhança, pode desenvolver serviços e criar novos atrativos para fidelizar o seu cliente.

\subsubsection{O Poder de Negociação do Varejista}

Historicamente, os varejistas eram muito dependentes do poder de algumas indústrias multinacionais, proprietárias de marcas fortes e consagradas no mercado. Entretanto, o crescimento na concentração do setor varejista e na concorrência entre marcas de produtos substitutos ocasionou uma inversão nesse poder. Se um varejista não compra uma marca de produto e isso implica na perda de consumidores leais a essa marca, significa que a indústria tem o poder, mas, se o consumidor aceita marcas substitutas e continua a freqüentar o pontode-venda, o poder está nas mãos do varejista (KUMAR, 1997).

Isso acontece porque o poder de cada parte está intrinsecamente relacionado com a interdependência das relações dos parceiros envolvidos, o poder do varejista depende do nível de dependência do seu fornecedor e vice-versa (HOGARTH-SCOTT, 1999). Quando uma empresa depende dos recursos de outra organização, acaba ficando suscetível às exigências desta, que usufrui do seu poder para maximizar seus interesses. Mas quando existe a mútua interdependência, os investimentos são compartilhados, e as partes executam suas atividades visando o benefício do canal como um todo. 
Poirier e Reiter (1996), consideram que os membros mais poderosos do canal de distribuição exercem sua força sobre os participantes mais fracos. A fraqueza, nessas situações, é derivada do fato de essas influências servirem apenas para criar associações instáveis entre as organizações, que tentam lucrar o máximo possível sobre os outros, em vez de trabalharem para o benefício coletivo. Nesse contexto, as dinâmicas do poder e da dependência são fatores importantes a serem considerados, pois eles permitem uma visão de como a estrutura do canal pode influenciar a performance do relacionamento.

O poder pode ser definido como a habilidade de um ator (A) conseguir de um outro ator (B) aquilo que ele deseja (HOGARTH-SCOTT, 1999). Dentro dos limites razoáveis, é possível conseguir tudo o que deseja, se estiver ciente das opções, testar suposições, correr riscos calculados e basear-se em informações sólidas, acreditando que se tem poder (MARTINELLI; ALMEIDA, 1998).

Negociação é um conceito em contínua formação, que está amplamente relacionado à satisfação de ambos os lados. Nierenberg (1981, p. 3), considera o conceito "como um negócio que pode afetar profundamente qualquer tipo de relacionamento humano e produzir benefícios duradouros para todos os participantes”. Fisher e Ury (1985) e Hodgson (1996), definem a negociação como um processo de comunicação bilateral que envolve um elemento de permuta e barganha, onde os agentes trocam recursos de valor por outro, visando uma decisão conjunta e a satisfação para todos os envolvidos.

A efetiva utilização de poder por uma das partes, conforme Coughlan (2001), tende a ocorrer de forma mais acentuada na medida em que a distribuição de poder entre os membros do canal seja mais desequilibrada. 
Nas décadas passada, o ponto determinante de uma negociação era basicamente o preço, e cada agente da cadeia de suprimentos buscava maximizar seus ganhos, mesmo que isso implicasse na redução dos lucros dos aliados comerciais (ALCÂNTARA, 1998; FLEURY et alli, 2000). Considerando o ambiente turbulento em que estão inseridas as empresas neste início de século, o preço voltou a ser a principal variável nas negociações entre varejistas e fornecedores. Grandes estabelecimentos negociam grandes volumes a preços mais baixos do que os menores, conseguindo oferecer aos consumidores preços mais acessíveis de um mesmo produto do que a concorrência.

As grandes redes varejistas conseguem concessões especiais de fornecedores, que nem sempre são justificadas por argumentos de aumento da eficiência pró-competitiva, e que, em muitos casos, apresentam efeitos adversos significantes sobre a competição em toda a cadeia produtiva. Segundo os autores, em geral, as condutas adotadas pelo varejo brasileiro apresentam grau de abuso do poder de compra ao serem unilaterais e restritivas. Destacam o fato de que o grau de interdependência do fornecedor, diante dos grandes varejistas, acentua o efeito negativo da adoção de tais práticas e que "qualquer argumentação é punida com o término da relação comercial". 


\subsubsection{A Faixa de Renda dos Consumidores que Habitam a Região das Lojas}

Os estudos realizados sobre a variação de preços de produtos em diferentes regiões têm obtido menos sucesso para encontrar a relação entre a diferença nos preços de produtos e variáveis demográficas de um mercado. Estudos recentes de preços de mantimento alcançaram resultados misturados. Hayes (2000), não identificou em sua pesquisa um relacionamento estatístico significativo entre preços de mantimento e o nível de renda de residentes de um mercado.

Por outro lado, Frankel e Gould (2001), encontraram em seus estudos que os preços são mais elevados nos mercados com mais desigualdade da renda. Os preços são mais elevados onde há uma renda mais baixa ou renda mais elevada e os preços mais baixos são encontrados nos mercados consumidores com renda entre estes dois grupos. Entretanto, o modelo dos autores não permite que determine se os resultados encontrados são devido às diferenças no comportamento do consumidor, nos custos, ou nas diferenças entre as características das lojas e a qualidade dos serviços fornecidos.

Resultados parecidos foram encontrados por pesquisadores do setor de restaurantes. Graddy (1997), encontrou que os preços são mais altos em regiões com uma proporção maior de consumidores de renda inferior. Porém, seu modelo não identificou se a diferença de preços observada poderia vir das diferenças de custos e condições de demanda, ou se reflete a estratégia de discriminação de preços entre varejistas.

Kaufman et alli (1997), afirmam que os preços de mantimento tendem a ser mais elevados em centros urbanos do que em mercados suburbanos. Alguns especulam que um acesso maior aos supermercados nos subúrbios é o fator responsável por essa diferença. Em comparação às 
lojas da cidade, os supermercados de subúrbios são aptos a oferecer os preços mais baixos e uma escala maior dos tipos de produtos, dos tamanhos do pacote e das escolhas por qualidade. MacDonald e Nelson (1991), encontram em seus estudos que uma cesta básica de produtos custa, aproximadamente, $4 \%$ menos nas lojas suburbanas do que em lojas da cidade.

\section{.11.7 O Preço da Concorrência}

Como foi discutido, Lambin (2000), considera que a escolha de uma estratégia de preços impõe o respeito a dois tipos de coerência: a coerência interna que contempla que o preço definido respeite as condições de custo e de rentabilidade da empresa, e a coerência externa, que exige um preço compatível com a sensibilidade dos compradores ao preço e com os preços praticados pela concorrência. Portanto, a estratégia de preço é influenciada pela situação da concorrência, caracterizada pelo número de empresas que atuam no mesmo segmento e do valor percebido do produto, resultante dos esforços de diferenciação produzidos pela empresa com o objetivo de alcançar uma vantagem concorrencial (KOTLER; KELLER, 2005 e STANTON; WALKER; ETZEL, 2001).

A definição do preço baseada na concorrência usa o balizamento dos preços com os do concorrente, ou seja, não precisa colocar o mesmo preço, mas a qualquer movimento do competidor há uma mudança proporcional nos preços da empresa. Esta prática é muito comum no caso dos oligopólios. Se houver um movimento de preços de um competidor, os outros fatalmente o seguirão ou perderão participação de mercado. Por isso os principais desafios que estas empresas enfrentam são: o bom controle dos custos, de modo a ficarem 
mais competitivas e suportarem uma agressividade de preços da concorrência e a capacidade de diferenciar os produtos, agregando serviços, de modo a fugir da guerra de preços.

Normalmente o competidor que tem a maior parcela de mercado exerce a liderança de preços, sendo que os outros são seguidores. O que permite ao líder direcionar preços é o maior conhecimento do mercado e do comportamento dos clientes sobre qualquer variação no composto de marketing. Scherer (1979) argumenta que uma visão mais realista do oligopólio pressupõe que as decisões de preço dos vendedores são interdependentes.

Um aspecto relevante é o nível de confiança entre os executivos das empresas competidoras. Caso seja baixo, esta indústria fica bastante susceptível a uma guerra de preços. Não se pode perder de vista que, mesmo um bom relacionamento com a concorrência, não impede que novos competidores entrem no mercado e ganhem participação à custa de preço. Portanto é importante que o preço seja alto o suficiente para dar lucros e baixo o bastante para criar barreiras de entrada.

Após a revisão bibliográfica o estudo foi complementado com uma pesquisa empírica para verificar a aplicação da teoria em três redes de supermercado atuantes no mercado nacional. Além disso, devido ao grande número de variáveis consideradas no momento da fixação do preço, é comum que cada empresa desenvolva o seu mecanismo, apreçamento, baseando-se em informações a respeito do seu mercado consumidor, o que torna o estudo do caso ainda mais interessante.

A escolha pelo varejo supermercadista é explicada pelo crescimento do setor e disponibilidade de dados existente. Outro ponto é a ênfase dada pelo varejo, ao preço como fator fundamental para a busca de um diferencial competitivo e para fidelizar os seus clientes. Depois de muitas mudanças, a economia nacional propiciou a chegada de novos competidores 
resultando no acirramento da disputa pelo mercado e na busca, tanto do setor industrial, quanto do próprio varejo por investimentos em pesquisas sobre o comportamento dos consumidores, com o objetivo de melhor entender suas necessidades e desejos.

O método de pesquisa escolhido, bem como os resultados do estudo encontram-se descritos nos tópicos a seguir. 


\section{MÉTODO DA PESQUISA DE CAMPO}

\subsection{Escolha do Método da Pesquisa de Campo}

Gay e Diehl (1992), explicam que existe uma diferença básica entre pesquisa em administração e pesquisa em outras áreas do conhecimento que é a natureza do fenômeno estudado. Nos estudos de administração, as situações estudadas são mais difíceis de serem explicadas e controladas, porque são complexas, envolvendo pessoas, instituições, ambientes em mudança e não relações simples de causa e efeito. Assim, além de não ser fácil controlar os diferentes aspectos pesquisados, é difícil generalizar e replicar os seus resultados (GAY; DIEHL, 1992).

Selltiz et alli (1974) afirma que a finalidade de uma pesquisa é descobrir respostas para algumas questões, mediante a aplicação de métodos científicos, que são desenvolvidos para intensificar a probabilidade de as informações obtidas serem utilizadas nas questões apresentadas e de serem seguras e imparciais. Embora uma tentativa de pesquisa não resulte, necessariamente, em uma informação fidedigna e imparcial, os métodos científicos têm maior probabilidade de êxito do que qualquer outro sistema conhecido do homem. O método científico de pesquisa é considerado como um conjunto de passos claramente determinados para obtenção de um conhecimento. São passos aceitos pelas pessoas que estudaram na área em que foi realizada a pesquisa (SELLTIZ et alli, 1974). 
O problema de pesquisa deste trabalho se enquadra na proposta sugerida por Campomar (2005), uma pesquisa em marketing, atrelada a uma revisão bibliográfica sobre um tema específico para avanço do conhecimento. Para o autor a pesquisa de campo em Marketing é útil para observar como, o que existe em prática se ajusta à teoria, ou ainda se a prática pode dar origem a uma nova teoria, modelo ou conceito: a pesquisa social empírica (CAMPOMAR, 2005).

Para que essa proposta seja cumprida, os tópicos a seguir apresentam e descrevem o tipo de pesquisa que melhor se enquadra no estudo realizado, a sua natureza e o método utilizado. É importante ressaltar que o entendimento dessas etapas pelo pesquisador é fundamental para que a organização do estudo empírico seja precisa e não prejudique a análise dos dados obtidos.

\subsubsection{O Tipo de Pesquisa}

Existem várias classificações sobre os tipos de pesquisa, entretanto os mais utilizados em trabalhos da área de administração são os de caráter exploratório e conclusivo. Os conclusivos são subdivididos em estudos descritivos e causais (SELLTIZ et alli, 1974; MATTAR, 1999). São descritivos quando o objetivo é apresentar as características de um fenômeno e causais quando buscam explicar o relacionamento entre variáveis. Entretanto os tipos de pesquisa não são excludentes, podendo se sobrepor em algumas situações. 
As pesquisas de caráter exploratório são mais adequadas quando há necessidade de maiores conhecimentos acerca de um fenômeno ou de conseguir uma nova compreensão sobre ele, possibilitando a formulação de problemas mais precisos e a criação de hipóteses (SELLTIZ et alli, 1974). A pesquisa conclusiva exige conhecimento das variáveis do problema a ser estudado e pode ser considerada descritiva quando seu objetivo é apresentar as características de um fenômeno e causal, quando busca evidenciar o relacionamento existente entre as variáveis do estudo (VERGARA, 1998).

Os estudos exploratórios possuem uma série de funções além da formulação do problema e das hipóteses, entre eles: (i) aumentar o conhecimento do pesquisador a respeito do fenômeno que deseja investigar em um estudo posterior; (ii) esclarecer conceitos e (iii) estabelecer prioridades para estudos futuros (SELLTIZ et alli, 1974).

Quando o objetivo da pesquisa é familiarizar-se com o fenômeno ou ainda conseguir nova compreensão deste fenômeno, os estudos do tipo exploratórios são mais indicados (SELLTIZ et alli, 1974). Como, no caso deste estudo, o objetivo é entender como são formados os preços dos produtos nos supermercados, pode-se afirmar que a pesquisa possui natureza exploratória. Além disso, possui abordagem semi-estruturada.

A pesquisa também é considerada descritiva, pois envolveu a apresentação de três casos que possibilitaram a obtenção de informações sobre apreçamento estratégico em supermercados, por meio da descrição das técnicas utilizadas pelas três empresas, mas não de conclusões que possam ser generalizadas. 


\subsubsection{A Natureza da Pesquisa}

A natureza da pesquisa relaciona-se com o tipo de dado trabalhado e como ele será analisado. Portanto, é o problema de investigação que determina se o estudo é qualitativo ou quantitativo.

Este estudo é classificado como uma pesquisa qualitativa, pois não enumera, nem mede os eventos estudados. Outra característica é a não utilização de procedimentos estatísticos na análise dos dados coletados e o envolvimento da obtenção de dados descritivos sobre pessoas, lugares e processos interativos, pelo contato direto do pesquisador com a situação estudada, visando à compreensão dos fenômenos, com base na perspectiva dos sujeitos do estudo (STRAUSS; CORBIN, 1990; GODOY, 1995). A pesquisa qualitativa possibilita a captação das opiniões e perspectivas dos indivíduos, ou seja, informações difíceis de serem obtidas por uma pesquisa quantitativa.

Os estudos qualitativos não envolvem estatística, o que não significa que são especulativos. Eles possuem objetividade e validade conceitual e contribuem para o meio científico (TRIVIÑOS, 1987). As críticas feitas ao método referem-se ao seu uso inadequado e não nas limitações. Rigor e confiabilidade também são características da pesquisa qualitativa (VIEIRA, 2004).

Bryman (1989) e Bogdan e Biklen (1992), destacam outras características da pesquisa qualitativa: (i) o ambiente é a fonte de dados - mundo empírico - e o pesquisador é o instrumento fundamental no contato direto e prolongado com o ambiente estudado; (ii) os dados coletados aparecem sob a forma de transcrições de entrevistas, anotações de campo, fotografias e desenhos, entre outros documentos; (iii) os pesquisadores qualitativos tentam 
compreender os fenômenos que estão sendo estudados a partir da perspectiva dos participantes, o que esclarece o dinamismo interno das situações, dificilmente compreendido pelos observadores externos e (iv) os pesquisadores têm proximidade do fenômeno que está sendo estudado, possibilitando uma melhor análise dos resultados encontrados.

Embora a pesquisa qualitativa demonstre subjetividade, é possível estabelecer procedimentos científicos por meio da definição de seu problema, das hipóteses, das variáveis e do estudo de campo, proporcionando maior objetivação (VIEIRA, 2004).

Rocha e Ceretta (1998) realizaram um estudo científico sobre a importância e a contribuição da pesquisa qualitativa na administração, concluindo que os estudos dessa natureza são capazes de descrever a complexidade de um problema, compreender e classificar processos dinâmicos vividos por grupos sociais, contribuir no processo de mudança de um grupo, além de possibilitar o entendimento das particularidades do comportamento dos indivíduos. $\mathrm{Na}$ mesma linha, Ghauri e Gronhaug (1995) acreditam que a pesquisa qualitativa é adequada em estudos de assuntos complexos e particulares.

Godoy (1995), explica que a abordagem qualitativa pode ser conduzida por diferentes caminhos, sendo três deles bastante conhecidos e utilizados no campo da administração: a pesquisa documental, o estudo de caso e a etnografia. O método utilizado no estudo será apresentado a seguir. 


\subsubsection{O Método da Pesquisa}

A pesquisa adota o método de estudo casos que, para Yin (1994), é um método potencial de pesquisa quando se deseja entender um fenômeno social complexo, pressupõe um maior nível de detalhamento das relações entre os indivíduos e as organizações, bem como dos intercâmbios que se processam com o meio ambiente nos quais estão inseridos. Tull e Hawkins (1976, p 323) afirmam que "um estudo de caso refere-se a uma análise intensiva de uma situação particular" e Bonoma (1985, p. 203) coloca que o "estudo de caso é uma descrição de uma situação gerencial".

Martins (1999), descreve o estudo de caso como uma investigação empírica que pesquisa fenômenos dentro de seu contexto real (pesquisa naturalística). Além disso, reúne o maior número de informações detalhadas, por meio de diferentes técnicas de coleta de dados, tais como entrevistas, questionário, observação participante, entrevista em profundidade, levantamento de dados secundários entre outros. O objetivo é de aprender a totalidade de uma situação e, criativamente, descrever a complexidade de um caso concreto. No estudo de caso utilizam-se enfoques exploratórios e descritivos, buscando identificar a multiplicidade de dimensões presentes numa situação.

Ludke e André (1986), afirmam que os estudos de caso buscam retrair a realidade de forma completa e profunda e o pesquisador procura revelar a multiplicidade de dimensões presentes em uma situação ou problema, focalizando-o como um todo. Bonoma (1985), explica que o método é útil quando o fenômeno a ser estudado é amplo e complexo, o conhecimento existente é insuficiente para suportar a proposição de questões causais e nos casos em que o fenômeno não pode ser estudado fora do contexto onde naturalmente ocorre. $\mathrm{O}$ autor defende 
o método como uma maneira indutiva para o desenvolvimento qualitativo do marketing como ciência.

O estudo de caso precisa, como todos os outros métodos de pesquisa científica, da elaboração de um projeto, de um plano de ação que permita a contemplação do problema de pesquisa de maneira lógica e otimizada (BONOMA, 1985). Lazzarini (1997), afirma que este é um método qualitativo que se caracteriza mais pela compreensão do fato, do que pela sua mensuração e permite utilizar várias fontes em evidência.

Considerando o propósito central da pesquisa, percebe-se a importância do estudo multicasos como objetivo de analisar o varejo supermercadista na cidade de São Paulo e as variáveis presentes na formação de preços dos produtos alimentícios por ele comercializados (YIN, 1994).

Campomar (1991), reforça essa importância ao afirmar que o estudo intensivo de um caso permite a descoberta de relações que não seriam encontradas de outra forma, sendo as análises e inferências em estudos de casos feitas por analogias de situações. Stake (1999), afirma que ultimamente o interesse pela realização de estudos que envolvem casos múltiplos é maior do que os que envolvem casos individuais. Jóia (2004), acredita que por meio da comparação de dados é possível reconhecer padrões e elaborar modelos que expressem a realidade.

Segundo Yin (1994), para o estudo de caso, os componentes de um projeto de pesquisa que são especialmente importantes são as questões do estudo, as proposições e as unidades de análise. Com relação às questões do estudo, a estratégia de estudo de caso é mais apropriada para responder, principalmente, às questões do tipo "como" e "por que", sendo assim a tarefa inicial do investigador precisar a natureza das questões do estudo (YIN, 1994; CAMPOMAR, 1991). As proposições direcionam a atenção para algo que deveria ser examinado dentro do 
escopo do estudo. A partir do momento em que as proposições são declaradas, o estudo começa a mover-se em alguma direção (YIN, 1994).

Lazzarini (1997) explica que, em função das unidades de análise, do número de casos analisados e dos métodos empregados, existem algumas variação no escopo da pesquisa baseada em estudo de caso. A unidade de análise é o objeto central da pesquisa e pode ser caracterizada por indivíduos, grupos ou organizações, bem como, um processo, uma atividade ou um comportamento. Além disso, está relacionada com o problema fundamental da definição do caso (Yin, 1994). Para esse estudo de caso, as unidades de análise são três redes supermercadistas localizadas na cidade de São Paulo.

Um ponto comum entre autores (YIN, 1989, BONOMA, 1985), é a recomendação de grande cuidado ao planejar a execução do estudo de caso para fazer frente às críticas tradicionais que são feitas ao método. Os passos a seguir, recomendados por Yin (1994), demonstram a preocupação com a organização do plano de pesquisa.

\subsubsection{Protocolo para os Estudos de Caso}

Conforme o conhecimento e o uso dos estudos de caso como método de pesquisa aumentam, as críticas em relação a esta técnica dão lugar a sua aplicação nos diversos campos da ciência. A relativa falta de conhecimento e da experiência em relação ao método do estudo de caso contribuiu para que falhas surgissem e alimentassem as críticas feitas por aqueles que não aceitam a técnica o que, atualmente, pode-se considerar resolvido (CAMPOMAR, 1991). 
Campomar (1991), afirma que o método científico é a maneira encontrada para legitimar o conhecimento empírico, sem o quê os resultados das pesquisas seriam de difícil aceitação.

Com o objetivo de aumentar a confiabilidade do método em questão, Yin (1994), ressalta a importância de estabelecer um protocolo. Para o autor, este protocolo deve conter o instrumento de coleta de dados, os procedimentos e as regras que devem ser seguidos ao longo do processo. Além disso, ainda de acordo com o autor, deve apresentar o seguinte conteúdo: (i) uma visão geral do estudo de caso; (ii) os procedimentos de campo; (iii) as questões de pesquisa e (iv) um guia para o relatório final. A seguir tem-se a explicação de cada um desses pontos.

\section{i. Visão Geral do Estudo de Caso}

A pesquisa de campo foi realizada para complementar a revisão bibliográfica da dissertação e proporcionar um maior entendimento sobre o apreçamento estratégico em redes de supermercado. Optou-se por três grandes grupos atuantes no Brasil, localizados na cidade de São Paulo, já que o projeto de pesquisa definiu a utilização do estudo de casos múltiplos.

A escolha das redes supermercadista foi feita por meio da classificação realizada pela Associação Brasileira de Supermercados (ABRAS) das maiores redes supermercadistas estabelecidas no país em faturamento e pelas redes que se encontram entre as cinco maiores, pois, acredita-se que as primeiras colocadas possuem maior conhecimento a respeito das variáveis que influenciam na formação dos preços finais de seus produtos da utilização de estratégias para diferenciar o seu posicionamento das empresas concorrentes do que as redes 
menores. A seguir foram realizados contatos com os responsáveis pela formação de preços dos produtos comercializados por essas redes e os principais gerentes envolvidos na escolha do método de precificação responderam à entrevista.

\section{ii. Procedimentos de Campo}

A coleta de dados foi feita por meio de entrevistas pessoais, orientadas por um roteiro semiestruturado não disfarçado (Apêndice 1), junto a diretores e gerentes das redes pesquisadas. Todas as entrevistas foram realizadas na cidade de São Paulo pela própria pesquisadora do estudo, possibilitando a obtenção de dados qualitativos primários.

O roteiro semi-estruturado parte de alguns questionamentos básicos que são elaborados por meio dos conceitos expostos na teoria e na experiência do pesquisador. A partir dos pontos abordados e dos dados fornecidos pelo entrevistado, surgem novas questões. Essa seqüência permite que o respondente participe, até certo grau, da condução da pesquisa (TREVIÑOS, 1987).

Embora tenha-se solicitado que as respostas fossem baseadas em fatos, fontes de dados secundários como jornais, revistas e informações nos sites das empresas também foram utilizadas para complementar as informações obtidas e reduzir a possibilidade de declarações tendenciosas, considerada uma das limitações do método escolhido.

Os dados foram coletados em janeiro de 2006. Buscou-se analisar e comparar os casos estudados, verificando as semelhanças, as diferenças e as particularidades, de forma a retratar um cenário condizente com a realidade presenciada. $\mathrm{O}$ objetivo não foi generalizar os 
resultados obtidos, já que a pesquisa é de natureza exploratória e tal generalização somente poderia ser feita por meio de uma maior representatividade da amostra.

\section{iii. Questões de Pesquisa}

Para direcionar as entrevistas, o roteiro semi-estruturado e não disfarçado foi elaborado. Esse roteiro foi dividido em duas partes. A primeira parte teve como objetivo coletar informações a respeito da empresa, como número de funcionários, faturamento, participação de mercado entre outras importantes para a caracterização da organização.

A segunda parte abordou o problema de investigação do estudo. As questões relacionadas a definição do apreçamento estratégico da empresa encontram-se descritas nesse ponto. Foram considerados os seguintes tópicos: o objetivo da determinação de preços, a análise dos preços dos concorrentes, o método de determinação de preços, a estratégia de seleção do preço final, a estratégia de adequação do preço e as variáveis que influenciam na fixação do preço dos produtos comercializados pelas redes.

Como se tratou de uma pesquisa qualitativa, o roteiro, caracterizado pela flexibilidade, não foi previamente testado. As questões de pesquisa foram averiguadas em cada rede supermercadista e os resultados e discussões, realizados para cada caso. 


\section{iv. Guia para o Relatório Final}

Após a coleta dos dados, os casos foram apresentados por meio de relatórios. Esses relatórios obedecem ao roteiro de entrevistas empregado e explica cada uma das questões formuladas para responder à pergunta de pesquisa, de acordo com as informações dadas pelos profissionais e das coletadas em fontes secundárias.

Os casos foram denominados como Caso 1 - Rede A, Caso 2 - Rede B e Caso 3 - Rede C, devido à confidencialidade das informações coletadas. Por tratar de um setor competitivo e porque o estudo aborda questões estratégicas, as redes não autorizaram a divulgação dos seus nomes.

As análises e considerações foram tratadas na conclusão do estudo, a partir da comparação dos casos com a teoria apresentada. A seguir estão descritos os estudos de casos realizados. 


\section{O ESTUDO MULTICASOS}

\subsection{Os Supermercados no Brasil}

Silveira e Lepsch (1997) explicam que, a exemplo do que aconteceu nas economias mais desenvolvidas, o setor de serviços no Brasil cresceu com maior rapidez do que os outros dois macro-setores, passando a ocupar, a partir da década de 90, o primeiro lugar no produto econômico, com cerca de 50\% do total. Dentro do setor de serviços encontra-se o varejo onde o supermercado ocupa um lugar de destaque. Este por sua vez, é o preferido de $85 \%$ dos consumidores urbanos, em termos de volume total de vendas de bens de consumo (alimentos e produtos de higiene e limpeza). Os outros $15 \%$ realizam suas compras em equipamentos tradicionais (armazéns, bares e mercearias, empórios e padarias), nos quais o auto-serviço é inexistente (SILVEIRA; LEPSCH, 1997).

Os supermercados surgiram na década de 30, nos Estados Unidos, já mostrando a sua força e a sua importância para o sistema de distribuição de alimentos em todo o mundo. Mas foi depois de 20 anos, na década de 50, quando os primeiros estabelecimentos desse tipo surgiram no surgiram no Brasil. O incentivo à proliferação dessa forma de comércio foi incentivada pelas grandes indústrias estabelecidas no país. A partir daí, o crescimento foi inevitável.

Nos anos 50, o conceito de auto-serviço foi consolidado, mas foi somente no final da década de 60 que os supermercados aumentaram sua participação no faturamento do varejo se firmando como o principal estabelecimento de distribuição de alimentos existente no mercado 
(SESSO FILHO, 2003). Segundo Lima (2001) e Senhoras (2003), os supermercados tornaram-se indispensáveis à estrutura de vida dos consumidores brasileiros e, desde então, observou-se uma tendência de crescimento contínuo do setor e a substituição ao modelo tradicional de distribuição de alimentos.

Atualmente, o varejo atravessa um processo de transformação intenso. Com o acelerado ritmo de consolidação, um número crescente de varejistas aparece na relação das maiores empresas do Brasil. No varejo supermercadista, o Carrefour e o Grupo Pão de Açúcar situam-se entre as cinco maiores empresas privadas brasileiras, com vendas anuais acima de quatro bilhões de dólares (CEV, 2005).

O ranking da ABRAS 2004 (LUKIANOCENKO, 2004) traz informações sobre o faturamento das redes que atuam no país e o grupo Pão de Açúcar registrou a primeira posição em 2004, com R $\$ 12,7$ bilhões, responsável por $14,7 \%$ do mercado, seguido pela rede Carrefour, com vendas brutas de $\mathrm{R} \$ 11$ bilhões e 12,6\% de participação. Em terceiro lugar aparece o grupo Sonae, com R\$ 3,7 bilhões, seguido pelo BomPreço (ainda independente do grupo Wal Mart, pelo qual foi adquirido) com $\mathrm{R} \$ 3,4$ bilhões e pelo Sendas, com R $\$ 2,2$ bilhões. Juntos, os cinco maiores grupos supermercadistas detêm uma participação 38\% aproximadamente. A tabela 1 apresenta dados sobre as dez redes com maior faturamento do setor supermercadista brasileiro e o quadro 11 traz algumas informações relevantes sobre as dez redes com maior faturamento no setor supermercadista brasileiro.

Ghisi (2005), cita que do total de lojas existentes no setor supermercadista, composto por quase 19 mil empresas, 45,6\% se encontram na região sudeste, seguida pelas regiões sul, norte-nordeste e centro-oeste, com 27,2\%,23,0\% e 4,2\%, respectivamente. A região sudeste permanece na primeira posição, em 2002, a mesma obtida no ano anterior, embora tenha registrado uma queda na participação sobre o faturamento do setor, que em 2002 era de 
59,3\%. A região Sul se destaca no crescimento da participação no setor, de $18,3 \%$, em 2002, para $19,1 \%$, em 2003.

\section{Tabela 1 - As dez redes com maior faturamento do setor supermercadista brasileiro}

\begin{tabular}{|c|c|c|c|c|c|c|c|}
\hline $\begin{array}{c}\text { Classificação no } \\
\text { Ranking }\end{array}$ & Empresa & Sede & $\begin{array}{c}\text { Faturamento Bruto } \\
\text { em } 2003(R \$)\end{array}$ & $\begin{array}{l}\text { Participação } \\
\text { sobre o Setor }\end{array}$ & $\begin{array}{l}\text { No. de } \\
\text { Lojas }\end{array}$ & $\begin{array}{c}\text { No. de } \\
\text { Funcionários }\end{array}$ & $\begin{array}{l}\text { No. de Check- } \\
\text { Outs por Loja }\end{array}$ \\
\hline 1 & $\begin{array}{l}\text { Companhia Brasileira } \\
\text { de Distribuição }\end{array}$ & SP & 12.788 .363 .000 & $15 \%$ & 497 & 55.557 & 16 \\
\hline 2 & $\begin{array}{l}\text { Carrefour Comércio e } \\
\text { Indústria Ltda. } \\
\text { Sonae Distribuição }\end{array}$ & SP & 11.028 .288 .954 & $13 \%$ & 329 & 45.899 & 22 \\
\hline 3 & Brasil S/A & RS & 3.732 .240 .000 & $4 \%$ & 148 & 20.923 & 23 \\
\hline & $\begin{array}{l}\text { BomPreço S/A } \\
\text { Supermercado do }\end{array}$ & & & & & & \\
\hline 4 & Nordeste & PE & 3.442 .710 .562 & $4 \%$ & 118 & 16.342 & 20 \\
\hline 5 & Sendas S/A & RJ & 2.273 .353 .718 & $3 \%$ & 76 & 12.057 & 21 \\
\hline Total 5 Maiores & & & 33.264 .956 .234 & $39 \%$ & 1168 & 150.778 & \\
\hline 6 & Wall-Mart Brasil S/A & SP & 1.940 .103 .602 & $2,10 \%$ & 25 & 7.032 & 28 \\
\hline 7 & $\begin{array}{l}\text { Cia Zaffari Comercio } \\
\text { e Indústria }\end{array}$ & RS & 1.182 .206 .802 & $1,30 \%$ & 26 & 7.552 & 33 \\
\hline 8 & de Consumo & SE & 940.161 .517 & $1 \%$ & 21 & 3.837 & 19 \\
\hline 9 & $\begin{array}{l}\text { Ltda. } \\
\text { Irmãos Bretas Filhos }\end{array}$ & SP & 923.612 .000 & $0,90 \%$ & 32 & 5.649 & 19 \\
\hline 10 & e Cia & MG & 811.210 .627 & $0,80 \%$ & 40 & 5.942 & 17 \\
\hline Total 10 Maiores & & & 39.062 .250 .782 & $45 \%$ & 1312 & 180.790 & \\
\hline
\end{tabular}

Fonte: Lukianocenko (2004).

Silveira e Lepsch (1997) argumentam que a importância do supermercado também pode ser medida pelo fato desse formato varejista ser um dos primeiros a estudar a disposição das mercadorias e o movimento dos consumidores no interior da loja. Os autores complementam explicando que o supermercado procura atrair a preferência dos clientes por meio de maior velocidade nos check-outs e layouts bem estruturados. 
As grandes empresas do setor, no Brasil, em sua maioria com bandeiras diferenciadas, já atuam tanto no segmento de hipermercados quanto no de supermercados. No segmento de supermercados, algumas trabalham com bandeiras diferentes, visando atingir públicos específicos (SAAB; GIMENEZ; RIBEIRO, 2000).

\section{Quadro 10: Dados sobre o setor supermercadista brasileiro}

\section{SETOR SUPERMERCADISTA BRASILEIRO}

O setor supermercadista brasileiro é composto por quase 19 mil empresas

$80 \%$ dos supermercados do território brasileiro são de pequeno porte e faturam menos que R\$100 mil mensais

$61,1 \%$ do total das lojas do setor supermercadista têm um número médio de até 7 check-outs

$30,3 \%$ das lojas supermercadistas do Brasil são jovens (têm, no máximo, cinco anos) e apenas 15,9\% têm mais de 20 anos

27\% dos supermercados do Brasil concentram-se no Estado de São Paulo (maior concentração por Estado brasileiro)

Apenas 2,1\% dos supermercados do Brasil têm área superior a $2500 \mathrm{~m}^{2}$ e são considerados lojas grandes

Apenas $0,3 \%$ das lojas supermercadistas do Estado de São Paulo faturam acima de R\$ 5 milhões mensais

Em 1999 foi vendido, em média, um supermercado por dia (concentração do setor)

Entre os anos de 2001 e 2002 foram investidos, no setor, mais de R \$ 1 bilhão

As 5 principais redes supermercadistas atuantes no Brasil detêm 38,1\% do faturamento anual de R\$

60 bilhões de reais do setor supermercadista brasileiro

Fonte: Ghisi, 2005

Ghisi (2005), explica que embora o supermercado seja um estabelecimento presente em todos os países, e até mesmo em quase todas as cidades de grande, médio e pequeno porte, e ser considerado um dos setores da economia brasileira que mais se modernizaram nas últimas décadas, sua criação e seu desenvolvimento podem ser considerados recentes. Algumas das tendências do setor são resultantes desse processo de modernização: investimentos em expansão, internacionalização do capital, segmentação de formatos, expansão das áreas geográficas de atuação e concentração (SAAB; GIMENEZ; RIBEIRO, 2000). 
As empresas líderes do setor supermercadista instaladas no território nacional, visando ampliar ou até mesmo manter suas participações de mercado, podem adotar duas formas estratégicas de expansão: construção de novos pontos de venda (expansão própria) ou compra de outras redes supermercadistas existentes (GHISI, 2005). A primeira, embora não seja o foco principal das redes, é adotada por algumas empresas como o supermercado Wal-Mart.

Por outro lado, a compra de outras redes supermercadistas consiste na estratégia de maior difusão no Brasil. Ghisi (2005) afirma que, no ano de 1999, um supermercado foi comprado por dia no país, retratando a adoção em larga escala dessa estratégia. Senhoras (2003), explica que, comparada à expansão própria, a aquisição ou fusão é mais vantajosa, a medida que acelera o conhecimento do mercado e dos hábitos dos consumidores da região.

Quanto à internacionalização do setor supermercadista brasileiro, é correto afirmar que a estratégia se desenvolveu principalmente na década de 90, período no qual o setor atravessou uma fase de grandes mudanças provocadas por fatores como a maior abertura da economia (âmbito externo) e estabilização econômica (âmbito interno), resultando em um cenário marcado pelo aumento de competidores internacionais (GHISI, 2005).

Senhoras (2003), explica que essa internacionalização levou ao aumento da concorrência em todo o mundo, resultando em um novo ambiente institucional proporcionado pelo processo de globalização. O autor cita como conseqüência do processo o surgimento de megacorporações, com capacidade de concentração e dominação econômica.

No setor supermercadista nacional, esse processo ocorre por meio de aquisições e fusões, em que as redes estrangeiras visam obter maior conhecimento da operacionalização do mercado brasileiro como, por exemplo, o Grupo Casino. 
Com relação aos formatos, Ghisi (2005) afirma que o consumidor brasileiro está migrando dos hipermercados para os supermercados de "vizinhança". Isso acontece porque, embora o atrativo dos hipermercados seja o preço, se os estabelecimentos de bairro conseguirem preços mais competitivos, como acontece hoje, junto com a vantagem de conveniência, maior oferta de serviços e localização próxima ao cliente, conquistarão muitos consumidores.

A estratégia de expansão das áreas geográficas de atuação é compreendida como o esforço dos supermercadistas em expandirem-se para outras regiões não atendidas no mercado doméstico por meio de aquisições e ampliar sua participação de mercado. Sato e Bessa Jr. (2000) destacam que a preferência de aquisição é por supermercados regionais, que já conhecem o perfil do consumidor local. Saab, Gimenez e Ribeiro (2000), citam como exemplo o Grupo Pão de Açúcar, que investe na atuação no Nordeste, mesmo tendo que enfrentar redes com liderança já consolidada na região.

A concentração de mercado é resultante da adoção das estratégias descritas anteriormente. As redes maiores adquirem redes de menores, surgindo um mercado concentrado, em poder dos hiper e supermercados. Em 2003, as dez maiores redes foram responsáveis por um faturamento bruto igual a $\mathrm{R} \$ 39$ bilhões, o que corresponde a $45 \%$ do faturamento do setor (LUKIANOCENKO, 2004).

A concentração prejudica o desenvolvimento dos supermercados menores, o que é considerado um fato é crítico, pois os pequenos estabelecimentos são os responsáveis pela empregabilidade de boa parte da mão-de-obra no Brasil e têm grande contribuição para a economia do país (DIEESE, 2003).

Dados da ABRAS (2005), mostram que, no Brasil, o processo de concentração se desenvolve gradativamente. A concentração se intensificou na segunda metade da década de 90 , mas o 
país ainda não atingiu grau elevado como a Alemanha, França e Inglaterra, onde as cinco maiores empresas detêm $76 \%, 67 \%$ e $60 \%$ do mercado, respectivamente.

Dada as principais características do setor supermercadista no Brasil, é preciso apresentar as informações mais relevantes sobre as unidades de análise da pesquisa. Os próximos tópicos descrevem cada um dos grupos analisados de acordo com o protocolo do estudo de casos.

\subsection{Caso 1 - Rede A}

A primeira rede foi fundada em 1948. Esse grupo foi o pioneiro no setor varejista de alimentos no Brasil e opera sob quatro diferentes formatos de supermercados, hipermercados e eletroeletrônicos, sendo essa uma das suas principais vantagens competitivas. Seu faturamento bruto foi de aproximadamente $\mathrm{R} \$ 15$ bilhões em 2004 e R $\$ 11,6$ bilhões nos nove primeiros meses de 2005, possui cerca de 58 mil funcionários e 550 lojas, distribuídas em 13 estados brasileiros, totalizando uma área de vendas de aproximadamente 980 mil metros quadrados.

O grupo opera com cinco unidades de negócios diferentes, com estratégias de venda e foco de atuação específicos e direcionados para consumidores de diferentes perfis. As participações em faturamento de cada uma das unidades são estão divididas, aproximadamente, em 48\% para a maior, $25 \%$ a segunda colocada, $16 \%$ a terceira, $9 \%$ a quarta e por fim, apenas $2 \%$ a menor divisão, que não foca a distribuição de alimento, nem higiene pessoal. 
Quanto a decisão de preços, primeiramente tem-se a definição dos objetivos para cada uma das unidades de negócio em que opera; a seguir são analisados a demanda e os custos de cada bandeira, são coletadas informações sobre os concorrentes, os métodos de estabelecimento dos preços são definidos e, posteriormente, adequados à realidade de cada formato.

Com relação aos objetivos de preço, os entrevistados da Rede A explicaram que, embora a empresa tenha como objetivo maior aumentar a sua participação no mercado, se analisarem cada unidade, percebe-se diferentes caminhos. Os hipermercados trabalham para aumentar o volume de vendas, os supermercados tem como foco o valor percebido pelo consumidor (dos produtos e dos serviços) e o objetivo é a liderança na qualidade dos produtos e as lojas de desconto também trabalham para aumentar o volume das vendas. Os gerentes enfatizaram que os objetivos particulares são diferentes, mas todos foram definidos para que a empresa conquiste maior participação.

A análise da demanda é realizada separadamente, já que os consumidores dos diferentes formatos possuem características diferentes, como o grau de sensibilidade ao preço. Os entrevistados explicaram que no hipermercado, o público-alvo procura pela melhor relação custo-benefício. Como as compras são mensais, principalmente, e a mercadoria adquirida é a cesta básica de produtos, os clientes são informados sobre os preços dos produtos e já estão acostumados a desembolsar uma certa quantia. Eles buscam marcas líderes ou segunda marca, a preços compatíveis com os oferecidos no mercado, geralmente optam pela rede que oferecer os bens a um preço melhor.

Não é só o preço que interfere na decisão de compra desse cliente. Ele também busca, segundo os respondentes, locais de fácil acesso, opções de produtos, facilidade de pagamento, um layout adequado (iluminação clara, música ambiente, agradável, higiene, produtos 
organizados nas gôndolas, corredores amplos para a passagem dos carrinhos, número suficiente de check-outs) e preços baixos.

Nos supermercados existe uma classificação entre as lojas. Elas são divididas em categorias top de linha, intermediária e popular. As consideradas top estão localizadas em bairros nobres, onde a renda dos consumidores é mais alta. Nesses locais os produtos comercializados são mais caros porque, de acordo com os entrevistados, os custos de manutenção são mais altos, os serviços oferecidos são mais amplos, o número de funcionários é maior e a sensibilidade do comprador é muito baixa. Os consumidores que buscam status são poucos sensíveis a preços elevados, pois estes produtos (nesse caso o próprio estabelecimento) inspiram prestígio e exclusividade. Além disso, os compradores desse supermercado acreditam que os bens comercializados apresentam qualidade superior.

Nas lojas intermediárias a sensibilidade do consumidor também é baixa (característica do público-alvo da empresa para esse formato), mas alguns itens de maior valor não entram da lista de produtos comercializados no local, assim como acontece nas lojas populares. Elas estão localizadas em regiões onde a renda dos clientes é um pouco mais baixa e, embora a busca por comodidade e serviços seja uma realidade, os compradores não estão dispostos a pagar um preço muito elevado por mercadoria de prestígio. Isso acontece porque a quantia pode significar uma boa parcela do seu orçamento financeiro.

As lojas de descontos atendem o público muito sensível ao preço. A rede não conseguia vender bem itens como frutas e legumes. Depois de analisar os hábitos das classes mais de renda mais baixa, os executivos da empresa descobriram que o consumidor C, D e E preferia comprar na feira por quatro motivos: (i) o local é um ponto de encontro; (ii) a pechincha é permitida; (iii) há um contato próximo com o vendedor e, o mais importante, (iv) há fartura. 
Com esses conceitos em mente, a rede reestruturou a área de hortifrutigranjeiros e colocou até uma banca de pastel na loja. As vendas subiram $25 \%$.

A estrutura de mercado é definida pelos poucos concorrentes que dominam o mercado. No varejo de alimentos as cinco primeiras redes são responsáveis por cerca de $40 \%$ do faturamento total. $\mathrm{O}$ dado demonstra a forte competição entre as empresas e segundo os entrevistados, também a importância da análise da concorrência.

A estimativa de custos são considerados os fixos e os variáveis. O preço estabelecido deve cobrir o custo total e permitir uma margem de lucro. Como cada formato se posiciona de forma diferenciada, os custos e as margens de cada um são calculados separadamente. Nos custos variáveis a Rede A considera os serviços oferecidos aos clientes e os gastos com publicidade e propaganda institucional.

A margem para os hipermercados segue a proposta pelos seus concorrentes, assim como nas lojas de desconto. No supermercado utiliza-se a margem que se mostra mais adequada ao seu objetivo. Os gerentes explicaram que a rede, de um modo geral, foca a eficiência e a redução de despesas operacionais, o que traz maior competitividade à companhia, uma vez que os ganhos são repassados aos preços, mesmo para os supermercados.

Os supermercados da rede trabalham com alta margem, já que se posiciona como prestadores de serviços qualificados. O público que freqüenta o estabelecimento procura: comodidade, variedade de produtos, alta qualidade, marcas conhecidas, facilidade de entrega, excelência no atendimento, localização privilegiada e próxima a sua casa, horários flexíveis e status. Os gerentes entrevistados afirmam que esse consumidor está disposto a pagar para encontrar tais facilidades na hora da compra. Por tanto os preços dos produtos oferecidos são compatíveis 
com o preço de mercado ("preço cheio"). Pode-se concluir que nos supermercados a estratégia utilizada é de preço acima do mercado.

Os gerentes da unidade estudada afirmam que o posicionamento do supermercado é: "supermercado de vizinhança, forte em produtos perecíveis, que oferece grande variedade de produtos, alta qualidade a preços competitivos, além do excelente atendimento aos clientes". Portanto, o preço não é o mais alto, nem o mais baixo que os preços do mercado, porém é percebido pelos clientes como mais alto do que o da concorrência direta, resultado da imagem sofisticada que o supermercado passa. Uma pesquisa realizada apontou que os preços percebidos não correspondiam com os preços reais oferecidos por suas lojas.

A análise da concorrência é feita constantemente pela empresa. O controle das ações dos competidores é, segundo os entrevistados, uma prática diária na empresa (shopping de preços). As informações sobre a concorrência são coletadas por funcionários das lojas, assim como acontece nos hipermercados: uma equipe preparada que visita os competidores localizados na área de influência de cada região dos supermercados. Os dados coletados ajudam a monitorar as ações da concorrência.

Embora o supermercado pratique preços acima do mercado, é preciso que saiba o nível praticado, pois se o valor estiver alto demais é provável que as vendas diminuam em algumas regiões. As vendas são analisadas diariamente e qualquer indício de queda no volume é rapidamente detectado e ações para reverter a situação são colocadas em prática.

Para os hipermercados o shopping de preços é importante se manter dentro do preço médio. Cada gerente de loja tem autonomia suficiente para adequar seu preço ao da loja vizinha. Os preços são adequados conforme a localização da loja, por isso a responsabilidade e autonomia descentralizada. 
A Rede A determina os preços de seus produtos por meio do método de mark-up, que consiste em atribuir uma margem ao custo total da unidade de produto e também utiliza o valor percebido pelo cliente. Nos hipermercados a política de apreçamento praticada é HILO, onde o varejista cobra preços mais altos, mas realiza promoções freqüentes.

A tática do preço isca é bastante utilizada pela empresa, por meio de promoções em um dia fixo da semana, como por exemplo, as quartas-feiras FLV (frutas, verduras e legumes) e para venda de produtos perecíveis. Os volumes de venda triplicam nesses dias, pois os descontos chegam a 50\% do preço e há forte comunicação na mídia de massa, como jornais e televisão. Descontos sazonais também são oferecidos para compras realizadas fora da temporada. É mais utilizada pelas Divisões de hipermercado e lojas de desconto.

Os supermercados trabalham com o preço por segmento de consumidores e preço por localização. Como explicado, anteriormente, pelos gerentes, o público dessa unidade de negócio é pouco sensível a preço, mas dependendo da região da loja e da renda de seus habitantes a sensibilidade pode apresentar maior grau. Assim, em regiões onde o poder de compra é mais alto os preços dos produtos são mais elevados do que em regiões habitadas por classes sociais que apresentam renda mais baixa. Para aumentar o valor percebido, descontos são utilizados apenas para produtos sazonais, vendidos fora da temporada nesse formato.

Quanto às variáveis que influenciam na formação do preço além dos custos, demanda e concorrência, os entrevistados afirmaram que são considerados para o formato hipermercado, os preços dos seus concorrentes, principalmente. A localização da loja e renda dos moradores da região são fatores importantes e exercem certa influência, entretanto são mais relevantes para a fixação dos preços nos supermercados da rede. Os descontos obtidos em negociações de preços com os fornecedores são repassados para os clientes da loja de desconto e hipermercados, mas não para os compradores de "status" e de conveniência do supermercado. 
Nos supermercados também são consideradas as marcas dos produtos. Por oferecerem grande variedade e sortimento, produtos líderes e outros inovadores, marcas diferenciadas de preçopremium e qualidade superior, os preços cobrados são considerados competitivos e "preços de mercado", sem descontos. Os serviços oferecidos estão dentro do cálculo de custos.

Nas lojas de desconto o é sortimento limitado. Elas atingem públicos mais específicos, de baixa renda, e têm raio de cobertura reduzido. Ela opera com poucos funcionários e poucos serviços para o cliente, o que resulta na oferta de preços mais competitivos, de acordo com os profissionais entrevistados. As mercadorias são expostas sem a utilização de material de ponto de venda, da forma mais simples e fácil possível. Não existem muitos serviços oferecidos e há poucos funcionários. Tais medidas são consideradas para que os custos sejam baixos e, assim, no cálculo do mark-up, o preço se torne bem acessível ao público desse formato.

Nessas lojas os poucos itens comercializados representam produtos da cesta básica da marca líder, uma marca inferior e muitos bens de marca própria. O objetivo nesse caso é o mesmo: reter mais da margem bruta gerada pela venda, resultante do baixo investimento em propaganda, em oposição às marcas nacionais.

\subsection{Caso 2 - Rede B}

A Rede B foi pioneira no Brasil no conceito de hipermercados. Chegou ao país em 1975, com a sua primeira unidade na cidade do Rio de Janeiro. A empresa possui mais de 11.000 lojas por todo mundo e está presente em 31 países. Ela emprega mais de 430.000 pessoas, sendo que 69\% trabalham na Europa, 20\% na América Latina e 11\% na Ásia. Conta com mais de 2 bilhões de clientes. 
Atualmente, opera com cerca de 80 hipermercados, 110 supermercados e 60 lojas de descontos. As lojas no país estão espalhadas por 11 estados e no Distrito Federal. Sua participação no mercado é de $12 \%$ do faturamento total do setor. No Brasil são 46.000 funcionários em todas as unidades de negócio de rede. Seu faturamento bruto foi de aproximadamente R $\$ 12$ bilhões em 2004.

O apreçamento estratégico do grupo também obedece a ordem de definição dos objetivos da empresa, seguidos pela análise da demanda e os seus custos. Em terceiro lugar está a coleta de informações sobre os concorrentes, em quarto a definição dos métodos de estabelecimento dos preços e, por fim, é feita a adequação.

Como objetivo de preço a rede B afirma ter bem claro que o foco está no aumento de sua participação no mercado. Embora, cada formato tenha um posicionamento distinto, esse objetivo é comum para todas as unidades de negócio do grupo. Os respondentes explicam que o foco maior está na estratégia geral da empresa e com todos buscando o mesmo resultado, é mais fácil conseguir atingi-lo.

A análise da demanda é também é realizada da mesma forma para todas as bandeiras, pois a sensibilidade a preço encontra-se no mesmo nível para todos os compradores-alvo desse grupo. Os entrevistados classificam o público da empresa como consumidores sensíveis. O que diferencia o cliente de uma Divisão para outra é a ocasião de compra. No hipermercado são realizadas as compras mensais, dos produtos da sexta básica e mercadorias para a casa.

No supermercado a procura é por produtos que terminaram antes da próxima compra mensal ou de alguns produtos mais elaborados para situações não programadas. Nas lojas de descontos os clientes são muito sensíveis aos preços, pois buscam o mais baixo e não procuram qualquer tipo de conveniência ou comodidade. Os gerentes explicaram ainda que o 
público-alvo dos hipermercados e supermercados procura pela melhor relação custobenefício. Os supermercados da rede focam na venda de alimentos e produtos perecíveis, enquanto os hipermercados oferecem itens de vestuários, higiene e limpeza, alimentos entre outros.

Algumas reformulações estão sendo realizadas nos supermercados do grupo, segundo os respondentes. A mudança é para aumentar a rentabilidade do formato. A nova estratégia da rede é baseada em quatro pilares: preço justo, variedade, qualidade e atendimento. No que se refere a variedade, haverá a ampliação do sortimento, relançamento de produtos marca própria e maior crescimento do número de alimentos perecíveis comercializados.

Os gerentes complementam explicando que todas essas ações visam melhorar a rentabilidade, mas sem aumentar os preços. As negociações de produtos das lojas continuam sendo feitas dentro do grupo. "O nosso serviço será de supermercado, mas com preços de hiper", afirmam.

Não é só o preço que interfere na decisão de compra dos clientes dos hipermercados e supermercados da empresa. Ele também busca, segundo os respondentes, locais de fácil acesso, opções de produtos, facilidade de pagamento, um layout adequado (iluminação clara, música ambiente, agradável, higiene, produtos organizados nas gôndolas, corredores amplos para a passagem dos carrinhos, número suficiente de check-outs) e preços baixos.

Ao estimar seus custos a Rede B calcula os classifica, assim como a Rede A em custos fixos e custos variáveis. No caso, o objetivo é que o preço fixado cubra o custo total e também permita margem de lucro. Os custos são estimados de forma conjunta para toda a empresa, e apenas os problemas com perdas (mercadorias vencidas, danificadas ou perdidas) é que são calculados para cada loja de cada formato e a tarefa é de responsabilidade dos gerentes do estabelecimento. 
Todo o orçamento para campanhas de mídia é realizado com uma porcentagem do lucro obtido pela empresa no ano anterior e são utilizados para a fortalecer a imagem institucional do grupo. As demais ações de mídia são divididas entre a rede e os fornecedores, que entram com verba para colocar produtos em promoções ou lançar novos itens. Os serviços oferecidos aos clientes são considerados nos custos da empresa no momento do cálculo de preço das mercadorias comercializadas.

Assim como nas outras empresas do setor, a análise da concorrência é feita constantemente pela empresa. A prática do conhecido shopping de preços é utilizada constantemente. O conceito é conhecido por todos e não requer nenhum tipo de estratégia específica, além do treinamento da equipe de funcionários responsáveis pela tarefa. As visitas são programadas para os competidores localizados na área de influência de cada loja das diferentes Divisões.

Os entrevistados explicam que, embora a decisão sobre a estratégia de apreçamento seja realizada em conjunto com a matriz, os gerentes da loja possuem autonomia suficiente para fazer mudanças de preços para se proteger das ações concorrenciais. São analisados: promoções atuais e passadas; os preços praticados em dias de prática do preço "isca"; descontos sazonais, entre outras táticas utilizadas pelos competidores.

A importância da análise dos concorrentes para empresa, segundo os respondentes, está na manutenção do preço médio (hipermercados e supermercados). Os produtos comercializados devem estar dentro do patamar de preços oferecidos no mercado e para isso, é fundamental acompanhar as estratégias das demais empresas do setor. Qualquer item que esteja acima do preço praticado pelo mercado, resulta em queda de vendas.

As lojas de desconto localizam-se em bairros mais afastados e de população com renda mais limitada. O formato concentra-se na periferia. Seu diferencial, em relação aos hipermercados, 
está na localização, próxima da casa dos clientes, como o "mercadinho" de bairro. O gerente da rede diz que a marca oferece um número reduzido de itens nas prateleiras, em comparação com os hipermercados.

Existem produtos de marca própria, que possibilitam aumento da margem de lucro. Ao desenvolver marcas próprias e aumentar a participação desses produtos dentro do conjunto ofertado aos consumidores, os varejistas podem reter mais da margem bruta gerada pela venda. Isso acontece porque as marcas próprias não precisam de grandes investimentos em propaganda, em oposição às marcas nacionais. Os outros produtos são de marcas líderes e marcas inferiores.

O formato oferece pouco ou nenhum tipo de serviço para o cliente final. As mercadorias são expostas nas gôndolas sem muita preocupação com a disposição. A estratégia nesse caso é de preço abaixo do mercado e, para conseguir manter o posicionamento, a redução dos custos é uma das principais preocupações. O objetivo é a maximização do volume de vendas e toda vantagem nas negociações com os fornecedores é repassada diretamente para o comprador, para oferecer preços baixos ao mercado.

O método de mark-up é o mais utilizado e nos hipermercados a política de apreçamento praticada, como na Rede A, é HILO, onde o varejista cobra preços mais altos e realiza promoções freqüentes. Para qualquer tipo e variedade de produtos comercializados pela Rede B existe um trabalho de gerenciamento de categoria onde são definidos quais serão as famílias de produtos, marcas e embalagens e suas respectivas margens objetivas bem como a periodicidade das pesquisas de preços na concorrência. Os gerentes explicam que o grau de importância atribuído para cada uma das famílias de produtos está associado a sua definição (dominantes "destino"; competitivos "tráfego"; convenientes "bandeira" e sazonais). 
Outra estratégia em comum entre as duas redes pesquisadas é o preço isca, também por meio de promoções em um dia fixo da semana. Os volumes de venda aumentam significadamente nesses dias, mas os gerentes não se dispuseram a comentar os números. A prática de descontos sazonais para compras realizadas fora da temporada pode ser observada, entre outras promoções de preços para combater o concorrente.

Com relação às variáveis que exercem influência no apreçamento dos produtos, os gerentes citaram principalmente os preços praticados pelos concorrentes. A localização e a renda dos consumidores influenciam de maneira indireta, já que cada loja busca estar compatível com o preço aceito pela população que habita determinada região onde o estabelecimento se encontra. Segundo os profissionais da Rede B, na hora de definir o preço as duas variáveis são estudadas, mas ainda é o preço dos competidores que guiam os níveis praticados.

Os gerentes chamam a atenção para um novo formato que a rede vem desenvolvendo. São hipermercados dirigidos às classes mais altas. Como operam com apenas uma loja, não a estrutura de preços ainda obedece às regras da matriz. A diferença, afirmam os entrevistados, está no sortimento de produtos e os serviços oferecidos, mas acreditam que a localização e a rede, nesse caso, terão mais peso para o apreçamento estratégico.

O poder de compra sobre os fornecedores, que permite negociações de preços menores, já é utilizado para conseguir oferecer aos consumidores preços mais acessíveis. Os entrevistados não consideram como influenciador, argumentado que tais negociações fazem parte da rotina do grupo, assim como dos seus principais concorrentes.

Nas lojas de desconto o sortimento é limitado. Elas atingem públicos mais específicos, de baixa renda, e têm raio de cobertura reduzido. Ela opera com poucos funcionários e poucos 
serviços para o cliente, o que resulta na oferta de preços mais competitivos, de acordo com os profissionais entrevistados.

\subsection{Caso 3 - Rede C}

A terceira rede tem lojas no Reino Unido, Alemanha, Argentina, China, Coréia do Sul, Porto Rico e Brasil. Iniciou as suas atividades no país em 1994 e hoje opera com 152 unidades, localizadas em 14 estados brasileiros. Seu faturamento bruto foi de aproximadamente US\$ 700 milhões em 2004. O grupo possui mais de 7000 empregados e trabalha atualmente com hipermercados, supermercados e atacados que atendem a pequenos comerciantes. Os formatos estão divididos em quatro bandeiras diferentes. A política do grupo é prosseguir com a abertura de novas lojas, consolidar sua presença na Internet e entrar no ramo de serviços bancários como financiadoras dos seus consumidores.

Há pouco tempo decidiu inaugurar lojas "compactas". São unidades pequenas, instalações simples, com menor sortimento de mercadorias e custos reduzidos. É uma tendência do varejo e o grupo decidiu apostar. Os entrevistados explicaram que seus consumidores querem preço e agilidade, exatamente o que este tipo de supermercado se propõe a oferecer. A política de preços do supermercado é a mesma que a rede aplica a todas as suas bandeiras.

Assim como as demais empresas pesquisadas, a Rede C estabelece seu preço considerando os custos, a demanda e os concorrentes, Possui o objetivo de ganhar maior participação de mercado e também utiliza o método de mark-up, para fixar o preço de seus produtos. 
O objetivo principal de preço é, como nos outros competidores, a maximização da participação de mercado e defesa do mercado. Os entrevistados argumentam que a razão é a proteção da área de influência e a criação de barreiras à entrada de novos concorrentes. Uma das estratégias é exatamente cobrir a oferta de preço baixo dos concorrentes, conforme explicado anteriormente. A estratégia adotada é a de preço abaixo do mercado para os hipermercados, com forte monitoramento dos preços dos competidores.

A estratégia utilizada pela Rede C é o EDPL em todas as unidades de negócios da empresa hipermercados, supermercados e atacados para pequenos comerciantes. Ela é reconhecida no mundo todo, pelos consumidores, como a pioneira na implementação dos preços baixos todo dia. Os entrevistados explicam que utilizam o EDLP para atrair o consumidor e conquistar sua lealdade, mostrando integridade na prática de seus preços.

Poucos artigos são colocados em oferta a cada mês. Os varejistas adotam o esquema EDLP por várias razões, a mais importante delas é que descontos e promoções constantes são dispendiosos e têm diminuído a confiança do consumidor em encontrar bons preços. No EDLP o cliente sabe o que encontrará. Os gerentes afirmam que, devido a essa estratégia, seus preços chegam a se igualar aos das lojas de desconto dos seus concorrentes, nos preços de produtos de higiene e limpeza.

Os hipermercados são considerados estabelecimentos para venda de grande quantidade de itens e compras mensais e é concorrente direto das redes A e B. O público-alvo é o mesmo das outras empresas, ou seja, clientes que realizam compras mensais e buscam um bom equilíbrio da relação custo-benefício. São clientes que reconhecem a estratégia praticada pelo varejista. 
Um dos métodos usados para combater e anular ações concorrenciais é garantir o preço mais baixo e cobrir qualquer oferta. A empresa tem tradição nessas atividades. Como opera com as margens semelhantes ao do competidor e os preços $15 \%$ mais baixos que da média do varejo, são conseguidos repassando-se as negociações com fornecedores. Só as promoções de preços resultantes da estratégia HILO utilizada pelas outras duas organizações é que ocasionam o uso de medidas de defesa.

Os consumidores são considerados pelos respondentes como altamente sensíveis a preço, pois buscam a oferta mais barata e fazem pesquisas de preço antes de decidir pelo local. O mesmo é valido para todos os formatos do grupo. Os compradores do atacado são comerciantes pequenos que buscam melhores condições de pagamento do que os oferecidos pela indústria.

Como os clubes atacadistas irão praticar uma margem própria para cobrir seus custos e não podem comercializar mercadorias com preços além do mercado, procuram as empresas que permitirem a compra de um bom volume a um preço relativamente baixo. Esse formato é um tipo de clube ou rede de compra, e os clientes são associados. O sortimento do clube de compras está dividido em produtos para escritórios, pizzarias, restaurantes, hotéis, lojas de conveniência, entre outros.

A estimativa de custos também considera os custos fixos e custos variáveis e o preço proposto deve cobrir o custo total da comercialização do item, além de garantir uma margem de lucro para a empresa. Existem também os problemas com perdas de mercadoria e estas são calculadas para cada loja de cada formato, sob responsabilidade dos gerentes de cada estabelecimento e os custos também são analisados separadamente para cada negócio da rede. Porém, várias ações são praticadas pelo grupo visando a redução de seus gastos. 
Devido a essa política de gestão de custos, a empresa é conhecida mundialmente por contribuir com a economia. Essa contribuição ao ciclo econômico consiste em três itens: pressionar os fornecedores para reduzir preços, usar tecnologia digital de primeira linha para baratear a gestão de seus estoques e pagar aos seus funcionários o menor salário possível, encolhendo os custos da empresa.

A empresa é referência em processos de gestão no varejo e no uso de tecnologia a serviço do negócio. Um exemplo é o sistema eletrônico de reposição de estoque. Por meio dele, rede e fornecedores ficam conectados 24 horas e têm informação do giro de cada produto na gôndola em tempo real. Assim, o varejista consegue agilizar o processo de reposição e os fornecedores têm acesso a detalhes como resultado de vendas dos produto por loja ou região.

Alguns fornecedores promovem ações de marketing no ponto de venda ou fazem eventuais mudanças nos produtos com os dados que são disponibilizados. Outro resultado dessa parceria é a redução de custos (cerca de $10 \%$ ao longo de toda a cadeia de suprimentos). Tais fatos possibilitam à rede colocar em prática a política EDLP.

Um fator que deve ser considerado na gestão de redução de custos da empresa é a não existência de estoque na loja, os produtos são alojados na parte superior da gôndola.

Os hipermercados da Rede C buscam oferecer o melhor sortimento pelo melhor preço sempre. A política de EDLP direciona todas as negociações realizadas com fornecedores e garante ao consumidor o menor custo da cesta de compras. Para honrar com esse compromisso, as lojas realizam semanalmente uma pesquisa de preços de produtos junto à concorrência local (shopping de preços) 
Os hipermercados ainda contam com um sortimento de 65 mil itens. Dentre elas, encontramse alimentos, hortifrutis, confecção, brinquedos, eletroeletrônicos, papelaria, perfumaria, artigos para casa, mesa e banho, limpeza, prática de esportes, jardinagem, pet shop entre outros. Todas as lojas possuem uma mini-galeria de serviços de conveniência. No local são encontradas lanchonetes, café, restaurantes, lavanderia, salão de beleza, ótica, banca de jornal e revistas, entre outros serviços alternativos. A idéia é trabalhar o conceito de one stop shop, lugar onde o cliente encontra de tudo em um mesmo local.

A tática do preço isca é novamente utilizada nesse caso. São realizadas promoções em um dia fixo da semana (terça feira da carne, quarta-feira da verdura, entre outras), mas os gerentes afirmam que a política de descontos é menos freqüente que nos concorrentes, já que optaram por oferecer preço baixo todos os dias.

Os volumes de venda também crescem consideravelmente e várias ações de comunicação são realizadas. Descontos sazonais são praticados constantemente para as compras realizadas fora da temporada, assim como em seus concorrentes. Os hipermercados realizam "saldões" depois das festas de final de ano, para reduzir o estoque de mercadorias comercializadas só para essa época do ano, como por exemplo, o Panetone.

Quanto às variáveis que influenciam na formação do preço, os respondentes consideram os preços dos seus concorrentes, a localização e renda dos moradores da região de influência de cada loja. Para isso, os gerentes também têm autonomia para modificar os preços das lojas que estão sob sua responsabilidade. Um exemplo dessa descentralização é a facilidade do cliente que apresenta um anúncio promocional impresso da concorrência, dentro da validade, com um preço inferior ao da rede, em conseguir a mesma oferta na loja, na hora e no caixa, sem burocracia. 
Os serviços prestados e os gastos com material promocional são considerados pela empresa como custos, entretanto, normalmente, os gastos são compartilhados com os fornecedores. Os entrevistados explicaram que os anúncios de produtos na mídia de massa (Televisão, Jornal e Revistas) são realizados em conjunto com os fabricantes e a empresa só arca com os custos de publicidade institucional. Para isso é reservada uma porcentagem das vendas anuais da empresa.

Os serviços oferecidos estão embutidos na margem e o poder de negociação com a indústria permite a compra de grandes volumes a preços mais baixos, descontos de pagamento à vista e bonificações. As bonificações são acordos realizados entre varejistas e fornecedores que permitem a entrega de mais mercadorias no lugar de descontos em dinheiro. A empresa repassa aos consumidores as reduções de preço que consegue na condição de uns dos maiores compradores.

O grupo também está investindo em novos projetos arquitetônicos. Com layout diferenciado e um conceito inovador, um novo hipermercado foi inaugurado. A unidade tem dois andares térreo e mezanino -e estabeleceu um novo modelo funcional com excelente aceitação dos clientes de regiões urbanas centrais e de alto índice populacional.

Novas ações promocionais são vinculadas ao novo modelo de loja. O objetivo da rede, de acordo com os entrevistados, é disponibilizar para os consumidores um sortimento de mais de mil itens a preços super negociados, reduzidos em até 10\%. É importante ressaltar que está não é uma ação promocional tradicional, pois a rede garante os preços por pelo menos noventa dias, diferente das ações da concorrência que em alguns casos têm curta duração. 


\subsection{Análise dos Casos}

Por meio da apresentação dos casos foi possível identificar como as redes de varejo formulam os preços de seus produtos. Todas as três empresas seguem os seis passos apresentados no referencial teórico. Porém, é importante ressaltar que nenhum dos gerentes entrevistados demonstrou realizar a tarefa de apreçamento de forma estruturada, ou seja, apesar das etapas serem seguidas, conforme o proposto por Kotler e Keller (2005), a determinação do valor cobrado por cada produto acontece intuitivamente e as análises necessárias são óbvias segundo os gerentes entrevistados. Determinar o preço dos produtos, portanto, não representa um problema.

A falta de conhecimentos técnicos mais aprofundados também fica clara quando percebe-se que as três empresas utilizam o mesmo método de apreçamento, o mark-up. Embora ele seja o mais utilizado pelas redes varejistas por sua simplicidade e facilidade de aplicação (LAMBIN, 2000a), não é necessariamente, a maneira mais adequada, pois apresenta várias limitações.

Uma delas diz respeito a definição de preços além do devido em mercados mais fracos e a preços abaixo do devido em mercados mais fortes, o que é considerado pelos estudiosos da área como sendo exatamente a direção oposta de uma estratégia prudente. Um outro problema é definir a grandeza da margem que deverá cobrir todas as despesas e permitir retorno. Além dos dois pontos, o método também não leva em consideração aspectos da demanda e dos concorrentes, focando apenas os custos.

Entretanto, a Rede A demonstrou que, apesar de utilizar o mark-up, também considera o valor percebido pelo consumidor para a Divisão de Supermercados. Isso acontece porque o negócio foi desenvolvido para atender as necessidades da população de renda alta (classes A e B), que 
possuem pouca sensibilidade à preços e busca comodidade, variedade, bom atendimento, excelência em serviços e mercadorias de alta qualidade e prestígio. Dessa forma, algumas outras variáveis, fora o custo são consideradas na estratégia de apreçamento. A decisão de agregar outros fatores (a renda dos clientes, o estilo de vida etc), foi resultado de várias ações e testes nas lojas. Esses experimentos são de responsabilidade de um consultor especializado em varejo, que atende grandes redes varejistas ao redor do mundo, traz constantemente novas idéias e sugere diferentes conceitos para serem aplicados.

As idéias que são aceitas para teste são aplicadas em certas lojas da rede (preferencialmente lojas em reforma). A avaliação dessas idéias e dos novos conceitos aplicados é feita de acordo com o resultado de vendas da loja modificada ou dos produtos pertencentes às sessões reestruturadas. $\mathrm{O}$ aumento nas vendas é utilizado como indicador de sucesso do novo modelo. Dessa forma, se as mudanças forem bem sucedidas, outras lojas serão igualmente remodeladas. Seguindo esse raciocínio, um nível baixo de vendas significa que o novo conceito não funcionou e, portanto, novas alternativas são avaliadas.

Tais ações demonstram que a estratégia de preço discriminatório é praticada pela Rede A. A empresa conhece os diferentes segmentos em que atua e para cada um determina um valor condizente com a possibilidade de compra do cliente. A compreensão dos diferentes graus de sensibilidade à preços é clara para a Rede A, que consegue diferenciar os segmentos de consumidores que atinge e adequar a sua estratégia para cada diferentes formato. Entretanto para as demais empresas, o conceito é difundido, mas não foi observada a utilização de métodos para adequar suas decisões baseadas nas diferentes características dos grupos de compradores. 
Os diferentes formatos das Redes B (hipermercados, supermercados e lojas de desconto) seguem o método de mark-up sem a influência de outro método. A mesma política HILO é trabalhada por todos. Mas cada um dos formatos possui seu próprio posicionamento e, portanto, atendem a públicos diferentes. Essa diferença é trabalhada no apreçamento apenas pela gestão de custos. Nas lojas de desconto o sortimento é menor, não há muitos funcionários para prestar serviços e os estoques são baixos. Todas as ações são para reduzir os gastos e praticar preços mais baixos. Essa atitude demonstra a possível falta de conhecimento a respeito das estratégias de adequação de preços que podem ser empregadas para operar com preços de acordo com as possibilidades das classes C e D.

Entre as estratégias a serem aplicadas está a prática de preços geográficos, preços discriminatórios, preços com descontos ou concessões. A única forma que as empresas varejistas estudadas demonstraram conhecer foi o preço isca. O preço geográfico também pode ajudar a reduzir custos, pois considera a região e os gastos com logística para entregar a mercadoria em locais diferentes. O preço discriminatório pode levar a rede a vender produtos com margem maior onde os consumidores são pouco sensíveis aos preços e os descontos e promoções favorecem as compras a vista ou em maior quantidade.

O shopping de preços é praticado por todos, devido à alta concorrência existente no setor (oligopólio). Todos conhecem a importância de monitorar as ações de seus competidores, seja para manter os preços dentro do mercado ou mesmo para se proteger. As empresas possuem equipes com funcionários preparados e treinados para a função que coletam as informações periodicamente, como apresentado na teoria.

Ao analisar a terceira rede (Rede C), fica clara a agressividade de suas ações para conquistar maior espaço no mercado. As suas ações estão sempre voltadas para redução de custos e focadas em prática de preços baixos. A estratégia EDLP é sinônimo da marca da empresa. 
Nos mais diferentes formatos, os preços com os fornecedores são fortemente negociados e todos os descontos conseguidos repassados para o consumidor. As escolhas quanto ao método de apreçamento (mark-up), preocupação com inovações tecnológicas e redução dos custos demonstram bastante coerência com o objetivo do varejista (oferecer preço baixo todo dia).

As variáveis que influenciam no apreçamento de cada unidade de negócio das redes não foram muito exploradas pelos gerentes nas entrevistas realizadas, mas é e evidente a importância do formato de canal na escolha das estratégias. Ao se posicionarem de formas diferentes e escolherem públicos diferentes para cada divisão, a influência do tipo de loja fica clara.

Os supermercados, ao se posicionarem como de "vizinhança" já consideram, automaticamente, a localização e a renda dos consumidores como fatores determinantes do preço. Conforme explicado na revisão teórica, os preços devem obedecer ao nível do mercado em que encontram-se, caso contrário perdem venda por estarem ou muito acima da concorrência ou comprometem os ganhos se praticarem preços muito abaixo.

Os produtos comercializados também têm influência. Nos formatos que possuem sortimentos limitados (lojas de desconto) a presença de marcas-próprias é grande, pois não precisam de investimentos em mídia de massa e podem ser comercializados à preços adequados ao orçamento das classes C e D. Os formatos que operam com sortimento maior (em variedade e profundidade), precisam trabalhar com o conceito de preço psicológico, associando o valor monetário alto com alta qualidade do produto. Nenhuma das redes afirmou utilizar a estratégia, porém a prática de preços psicológicos é tradicional já na indústria e é repassada para o ponto de venda. 
As marcas líderes geralmente apresentam preço superior, para traduzir ao cliente a qualidade de seu produto e esse preço é repassado pelas redes para o consumidor final. As redes supermercadistas trabalham com marcas líderes para melhorar a imagem que constroem na mente do comprador. A marca que o cliente deseja precisa estar disponibilizada nas gôndolas ou o consumidor não se sentirá satisfeito com a experiência de compra (KUNKEL; BERRY, 1968; LINDQUIST 1974; DOYLE; FENWICK, 1974; ENGEL; BLACKWELL, 1995). Assim também é possível afirmar que as marcas têm influência na determinação dos produtos comercializados pelos supermercadistas.

As informações das redes que confirmam essa observação é a comercialização dos mesmos produtos, de mesma marca e características a preços mais altos em lojas localizadas em regiões nobres e a preços mais baixos em lojas localizadas na periferia da cidade.

As negociações fazem parte do cotidiano de todas as empresas. Como as redes estão entre as dez maiores, em faturamento (ABRAS, 2005), a compra em volume é considerável e o poder sobre os fornecedores também. Há anos, uma negociação era determinada, principalmente, pelo preço. Com a concorrência acirrada, o preço voltou a ser a principal variável nas negociações entre varejistas e fornecedores. As maiores empresas negociam grandes volumes a preços mais baixos do que os menores, conseguindo oferecer aos consumidores preços mais acessíveis de um mesmo produto do que a concorrência.

Entretanto, conforme já citado, a variável que, claramente, exerce maior influência na formação dos preços das mercadorias comercializadas pelas redes é o formato do canal. Mesmo utilizando o mesmo método de apreçamento, as lojas de diferentes formatos praticam políticas diferentes. Como o posicionamento e o público-alvo são distintos, as ferramentas para adequar os preços dos produtos não são as mesmas. Cada público tem suas características, poder de compra, rendas distintas e ocasiões de compra diferentes. 
Além disso, os supermercados de "vizinhança" oferecem mais serviços para o cliente final. Como localizam-se próximo à residência do consumidor, geralmente, oferecem serviços de entrega, por exemplo. Serviços adicionais aumentam o custo interno do varejista e, portanto, para conseguir cobrir todos os gastos, as margens consideradas no cálculo do mark-up não podem ser tão baixas. Por mais que o foco seja a redução de custos, mesmo por meio de melhores negociações com os fornecedores (como no caso da Rede C), os produtos não têm os mesmos preços que as lojas de hipermercado.

Nas lojas de desconto, como os serviços são poucos e a estrutura disponível é mais simples (não têm estoque, as mercadorias são guardadas por cima da gôndola), o número de funcionários restrito e poucos investimentos em comunicação e merchandising os custos abaixam e é possível praticar preços abaixo da média do mercado. Há também a comercialização de marcas próprias que ajudam no ganho maior.

Para facilitar a visualização das estratégias utilizadas pelas redes supermercadistas, no apreçamento dos produtos que comercializam, o quadro 11 foi elaborado.

A seguir apresenta-se a conclusão da dissertação, bem como as limitações encontradas e as sugestões de estudos futuros. 
Quadro 11: Resumo das estratégias de apreçamento utilizadas pelas redes varejistas pesquisadas

\begin{tabular}{|c|c|c|c|}
\hline $\begin{array}{c}\text { Estratégias / } \\
\text { Redes }\end{array}$ & Rede A & Rede B & Rede C \\
\hline $\begin{array}{l}\text { Objetivo de } \\
\text { Preço }\end{array}$ & $\begin{array}{l}\text { - Participação de } \\
\text { mercado; } \\
\text { - Valor percebido pelos } \\
\text { consumidores } \\
\text { (supermercado) }\end{array}$ & $\begin{array}{l}\text { - Participação do } \\
\text { mercado. }\end{array}$ & $\begin{array}{l}\text { - Participação do } \\
\text { mercado. }\end{array}$ \\
\hline $\begin{array}{l}\text { Análise da } \\
\text { Demanda }\end{array}$ & $\begin{array}{l}\text { - Consumidores sensíveis } \\
\text { a preços nos } \\
\text { hipermercados e lojas de } \\
\text { desconto; } \\
\text { Consumidores pouco } \\
\text { sensíveis nos } \\
\text { supermercados }\end{array}$ & $\begin{array}{l}\text { - Consumidores sensíveis } \\
\text { a preços em todos os } \\
\text { formatos; } \\
\text { - Busca da melhor relação } \\
\text { custo-benefício. }\end{array}$ & $\begin{array}{l}\text { - Consumidores sensíveis } \\
\text { a preços em todos os } \\
\text { formatos; }\end{array}$ \\
\hline $\begin{array}{l}\text { Estimativa de } \\
\text { Custos }\end{array}$ & - Fixos e variáveis. & - Fixos e variáveis. & $\begin{array}{l}\text { - Fixos e variáveis; } \\
\text { - Controle sobre gastos e }\end{array}$ \\
\hline $\begin{array}{l}\text { Análise da } \\
\text { Concorrência }\end{array}$ & - Shopping de preços & - Shopping de preços & - Shopping de preços \\
\hline $\begin{array}{l}\text { Seleção do } \\
\text { Método }\end{array}$ & - Mark-up & - Mark-up & - Mark-up \\
\hline $\begin{array}{l}\text { Adequação } \\
\text { do Preço }\end{array}$ & $\begin{array}{l}\text { - Descontos sazonais; } \\
\text { - Preço isca; } \\
\text { - Preço psicológico } \\
\text { (supermercados); } \\
\text { - Preços por segmento } \\
\text { (supermercados); } \\
\text { - HILO (hipermercados). }\end{array}$ & $\begin{array}{l}\text { - Descontos sazonais; } \\
\text { - Preço isca; } \\
\text { - HILO (todos os } \\
\text { formatos). }\end{array}$ & $\begin{array}{l}\text { - Política EDLP para } \\
\text { todos os formatos; } \\
\text { - Preço isca. }\end{array}$ \\
\hline $\begin{array}{l}\text { Variáveis que } \\
\text { influenciam }\end{array}$ & $\begin{array}{l}\text { - Localização da loja; } \\
\text { - Renda do consumidor; } \\
\text { - Formato do canal; } \\
\text { - Marcas do produtos. }\end{array}$ & $\begin{array}{l}\text { - Formato do canal; } \\
\text { - Marcas do produtos; } \\
\text { - Poder sobre os } \\
\text { fornecedores. }\end{array}$ & $\begin{array}{l}\text { - Poder sobre os } \\
\text { fornecedores } \\
\text { - Renda dos } \\
\text { consumidores; } \\
\text { - Formato do canal; } \\
\text { - Marcas do produtos. }\end{array}$ \\
\hline
\end{tabular}

Fonte: Elaborado pela autora

A seguir apresenta-se as conclusões do estudo, suas limitações e sugestões de estudos futuros. 


\section{CONCLUSÕES}

Este estudo teve como objetivo analisar a formação de preços de produtos em supermercados. Para que o objetivo fosse cumprido, uma revisão bibliográfica foi desenvolvida e abordou conceitos sobre demanda, custos, métodos de apreçamento, técnicas de adequação de preços e variáveis que influenciam nessa decisão.

Um estudo multicaso em três redes supermercadistas foi elaborado para analisar como os temas abordados na revisão são utilizados na prática por algumas empresas do setor. Para isso desenvolveu-se um protocolo com os passos necessários para o desenvolvimento da pesquisa empírica. Apresentou-se também o histórico, a situação atual e as principais tendências do varejo, para o entendimento das circunstâncias atuais de concorrência e crescimento das redes.

Após essa apresentação, os casos foram descritos e analisados pela autora. Baseando-se nessas análises, foi constatado que, atualmente, com o mercado cada vez mais competitivo e com o fácil acesso dos consumidores à comparação de preços, a decisão sobre as estratégias de apreçamento tornou-se fundamental para o bom desempenho das redes supermercadistas que visam ganho de vantagem competitiva.

O estudo de multicasos demonstrou que os métodos de apreçamento e de adequação de preços são ainda pouco utilizados pelas redes estudadas, no que se refere à variedade de técnicas existentes para serem aplicadas a situações diferentes. As empresas demonstraram o uso adequado do mark-up e de estratégias de descontos (peço isca e descontos sazonais), porém, de acordo com a teoria proposta, tais métodos apresentam limitações que podem, alongo prazo, prejudicar o alcance dos objetivos de rentabilidade e participação de mercado dos grupos supermercadistas analisados. 
Cabe ressaltar que, até hoje, as empresas estudadas têm conseguido atingir seus objetivos de preço por meio da utilização do método de mark-up em conjunto com as análises de demanda e concorrência, segundo os resultados de vendas e a colocação no ranking da ABRAS. Entretanto, o setor busca novas tecnologias para redução de custos e também apresenta outras estratégias para fidelizar os seus clientes, que consideram outras variáveis além dos custos.

O acompanhamento das ações dos competidores, por meio do shopping de preços, de cada loja em diferentes regiões tem permitido às redes a manutenção de uma consistência sobre suas estratégias e a prática de técnicas de defesa como cobrir ofertas ou melhores negociações com seus fornecedores para operar com preços dentro do mercado. Porém, as empresas focam nas estratégias dos concorrentes e acabam por desenvolver ações muito próximas e parecidas com as dos competidores, enquanto poderiam analisar com maior profundidades os seus públicos e oferecer vantagens de acordo com o estilo de vida, a renda e as necessidades de cada segmento de mercado que atende.

A Rede C, por exemplo, considera que todos os seus consumidores têm o mesmo nível de sensibilidade à preços. Mas eles possuem hábitos de compra diferentes e freqüentam formatos de loja distintos, o que demonstra que nem todas as características são as mesmas. Caso utilizasse o preço discriminatório, poderia diferenciar as suas bandeiras e atingir, talvez de forma mais eficaz, o objetivo de maior participação de mercado. A Rede A, embora não demonstre conhecimento suficiente sobre o conceito de preço discriminatório, é a única, entre as organizações estudadas, que opera com estratégias diferentes para cada público que freqüenta suas diferentes divisões.

O foco para a redução dos custos e prática de maiores margens é nas negociações com fornecedores. Apenas uma das empresas admitiu o uso de ferramentas tecnológicas para diminuir custos. A aplicação de técnicas de apreçamento para alcançar esse objetivo não foi 
verificada, o que demonstra a existência de espaço para o desenvolvimento da gestão de preços nas empresas pesquisadas.

É importante ressaltar que, à medida que os especialistas em varejo buscam mais bases científicas e confiáveis para auxiliar na tomada de decisões quanto à formação de preços de dos produtos que comercializam, é essencial que possuam uma compreensão clara dos conceitos e ferramentas disponíveis, assim como o conhecimento das demais técnicas de adequação, como preços geográficos, que permitem também a tão desejada redução de custos.

Os estudos científicos sobre preços têm demonstrado novos modelos, como o custo-alvo, que permitem que as decisões sobre apreçamento sejam mais confiáveis de próximas às necessidades e possibilidades financeiras dos clientes finais. Conforme os métodos vão sendo aprimorados, menor a chance das estratégias e dos planejamentos de precificação falharem. Porém é preciso que as redes supermercadistas deixem de analisar somente seus competidores e de desenvolverem ações para se proteger dos ataques e observem mais de perto as atitudes, características e diferentes estilos dos seguimento de compradores que atingem ou pretendem conquistar. 


\subsection{Limitações}

Campomar (1991), explica que tanto os métodos quantitativos, quanto os métodos qualitativos possuem suas limitações e estas devem ser claramente mencionadas nos trabalhos científicos.

As limitações do presente trabalho referem-se, primeiramente, a natureza do método. Embora as escolhas tenham permitido o alcance dos objetivos propostos no estudo, existem algumas considerações importantes a serem feitas.

A primeira delas refere-se à amostra pesquisada. Por se tratar de uma amostra não representativa, os dados coletados e analisados, bem como as conclusões apresentadas não podem ser generalizados para todo o setor supermercadista. As observações só devem ser consideradas para as três empresas que participaram do estudo, mesmo que as companhias estejam entre as maiores em faturamento. Outro fator que impede a generalização é o seu objetivo exploratório. A dissertação foi baseada em revisão de literatura e estudos de caso.

Um ponto importante refere-se ao próprio setor supermercadista. Como trata-se de um mercado competitivo, as empresas não aceitaram a divulgação de alguns dados e se restringiram apenas a comentar quais são as estratégias gerais utilizadas para o apreçamento dos produtos que comercializam. Estratégias específicas quanto ao posicionamento, futuras mudanças, desenvolvimento de novas tecnologias e práticas, e variáveis utilizadas não foram expostas por nenhuma das redes. As conclusões sobre esses aspectos forma baseadas em alguns comentários e pesquisa de dados secundários. 


\subsection{Sugestões para futuros estudos}

Estudos futuros podem comparar a pesquisa realizada com os resultados obtido em outras redes supermercadistas atuantes no país. Nessa dissertação foram analisadas três das dez maiores empresas em faturamento. $\mathrm{O}$ estudo poderia identificar se as os passos seguidos para a determinação de preço e as variáveis influenciadoras são as mesmas identificadas nessa pesquisa. Com uma amostra maior, os resultados poderiam trazer informações mais precisas a respeito do apreçamento estratégico em supermercados.

Um outro estudo pode coletar dados primários de preços de produtos em diferentes formatos e verificar a influência de das variáveis propostas de forma estatística. $\mathrm{O}$ grau de influência de cada uma pode ser medido e os seguintes objetivos verificados:

- A influência da marca no apreçamento estratégico supermercadista;

- A influência da faixa de renda dos consumidores que habitam as regiões de cada loja;

- A influência do formato do canal de distribuição na fixação de preços dos produtos comercializados pelos varejistas;

- A influência da região onde cada loja se localiza na precificação de produtos comercializados pelos supermercados;

- A influência do poder do canal de distribuição sobre os seus fornecedores e;

- A influência do preço do concorrente na determinação dos preços dos produtos de uma rede;

Outras possibilidades dizem respeito ao estudo da formação de preços em tipos diferentes de varejo, comparando o setor supermercadista com os outras empresas de serviços. 


\section{REFERÊNCIAS}

AAKER, David A. Building Strong Brands. New York: The Free Press, 1996.

AAKER, David A. Managing Brand Equity: Capitalizing on the Value of a Brand Name. New York: The Free Press, 1991.

ACNIELSEN. Disponível em <http://www.acnielsen.com.br/>. Acesso em 11/nov/ 2004.

ALCÂNTARA, Rosane L.C. A Gestão estratégica dos canais de distribuição: um exame da evolução do atual estágio do relacionamento entre atacado de entrega e a indústria. 1997. 194f. Tese (Doutorado em Administração) - Fundação Getúlio Vargas, São Paulo.

AMERICAN Marketing Association - AMA. Disponível em $<$ http://www.marketingpower.com/>. Acesso em 15/fev/2005.

ANCARANI, Fábio; SHANKAR, Venkatesh. Price Levels and Price Dispersion Within and Across Multiple Retailer Types. Academy of Marketing Science Journal. (32) v. 2; p. 176, 2004.

ASSOCIAÇÃO Brasileira de Supermercados - ABRAS. Disponível em http://www.abrasnet.com.br/. Acesso em 15/maio/2005.

BEISEL, J. L. Contemporary Retailing. 2 ed. New York: MacMillan, 1993.

BESANKO, David; DRANOVE, David; SHANLEY, Mark. The Economics of Strategy. $2^{\text {nd }}$. ed. John Wiley and Sons, 2000.

BLOEMER, Josée; SCHRODER, Gaby O. Store satisfaction and store loyalty explained by customer and store related factors. Journal of Consumer Satisfaction, Dissatisfaction and Complaining Behavior. V. 15, 2002.

BLOEMER, Josée; RUYTER, Ko. On the relationship between store image, store satisfaction and store loyalty. European Journal of Marketing. V. 32 (5/6), p. 499-513, 1998. 
BONOMA, Thomas V. - Case Research in Marketing: Opportunities, Problems, and Process. Journal of Marketing Research, Vol XXII, May 1985.

BOGDAN, R.C.; BIKLEN, S.K. Qualitative research for educations: an introduction to theory and methods. Boston: Allyn and Bacon, 1992.

BRYMAN, A. Research methods and organization studies. New York: Routledge, 1989.

CAMPOMAR, Marcos C. Do uso do "Estudo de Caso" em Pesquisas para Dissertação e Teses em Administração. Revista de Administração. São Paulo, v.26, no 3, p. 95-97, julhosetembro 1991.

Pesquisa em Marketing e Seus Problemas versus Pesquisa de Marketing. In: XXIX EnANPAD, 2005. Brasília. Anais... Brasília, DF, 2005. CD-ROM.

CAO, Yong; GRUCA, Thomas S. Retail price dispersion: Consumer, firm, and market determinants. American Marketing Association. Conference Proceedings. (12), p 298, 2001.

CENTRO DE PESQUISA NO VAREJO - CEV. O Varejo no Brasil. Disponível em http://www. www.fgvsp.br/cev/ Acesso em 30. maio. 2005.

CHURCHILL JR, Gilbert A.; PETER, J. Paul. Marketing: criando valor para os clientes. 2 ed. São Paulo: Saraiva, 2003.

CHURCHILL, Neil. Don't let inflation get the best of you. Harvard Business Review. march/april, 1982.

COREY, E. Raymond. Industrial marketing: cases and concepts. 4. ed. New Jersey: Prentice Hall, 1991.

COUGHLAN, Anne T.; ANDERSON, Erin; STERN, Louis W; EL-ANSARY, Adeli I. Marketing Channels. New York: Prentice Hall, 2001.

CYRILLO, Denise.C. O papel dos supermercados no varejo de alimentos. São Paulo: Instituto de Pesquisas Econômicas, 1987.

CZINKOTA, Michael. R. Marketing as melhores práticas. Porto Alegre: Bookman, 2001. 
DIEESE. Redes estrangeiras compram supermercados brasileiros. Índice do Boletim DIEESE, boletim 215, set./out.1999. Disponível na URL: http://www.diese.org.br/bol/esp/estset99.html. Acesso em: 10 maio 2005.

DOYLE, P; FENWICK, I. How store image affects shopping habits in grocery chains. Journal of Retailing. V. 50 (4). p 39-52, 1974.

ECR BRASIL. Gerenciamento por Categoria. São Paulo, Coleção 1, Livro 6, 1998.

ENGEL, James F.; BLACKWELL, Roger D.; MINIARD, Paul W. Consumer Behavior. $8^{\text {th }}$ ed. Orlando: The Dryden Press, 1995.

FERRELL, O. C. et al. Estratégia de Marketing. São Paulo: Atlas, 2000.

FISHER, R.; URY, W. Como chegar ao sim: a negociação de acordos e concessões. Rio de Janeiro: Imago, 1985.

FLEURY, F.P.; WANKE, P.; FIGUEIREDO, K.F. (org.). Logística empresarial: a perspectiva brasileira. São Paulo: Atlas, 2000.

FRAM, Eugene H.; McCARTHY, Michael S. The true price of penalties. Marketing Management. p. 49-56. October, 1999.

FRANKEL, David M.; GOULD, Eric D. The retail price of inequality. Journal of Urban Economics. 49:219-39, 2001.

GAY, L.R.; DIEHL, P.L. Research methods for business and management. New York: MacMillian Publishing Company, 1992.

GHAURI, P.N.; GRONHAUG, K. Research methods in business studies: A practical guide. New York: Prentice Hall, 1995.

GHISI, Flávia A. Fatores Críticos na Sustentabilidade das Centrais de Negócios do Setor Supermercadista. 2005. Tese (Doutorado em Administração) - Faculdade de Economia, Administração e Ciências Contábeis, Universidade de São Paulo, São Paulo.

GODOY, Arilda S. Introdução à pesquisa qualitativa e suas possibilidades. Revista de Administração de Empresas, São Paulo, v.35, n.2, p.57-63, mar./abr. 1995. 
GRACIOSO, Francisco. Marketing: o sucesso em 5 movimentos. São Paulo: Atlas, 1997.

GRADDY, Kathryn. Do fast-food chains price discriminate on the race and income characteristics of an area? Journal of Business and Economic Statistics. 15:391-401, 1997.

GRANT, R. M. Contemporary Strategy Analysis: concepts, techniques and aplications. 4 ed. Oxford: Blackwell Business, 2002. 551p.

GUIMARÃES, D.G.; VENTURA, I.F.; ZIMET, M. VALLE, M.F.B.; HABENSCHUSS, S. Influência das características de microregiões geográficas na definição do perfil das lojas de supermercados na cidade de São Paulo. In: ANGELO, Claudio F; SILVEIRA, José Augusto G. Varejo Competitivo, São Paulo: Saint Paul Institute of Finance, v.8, 2003.

HAYES, Lashawn R. Are prices higher for the poor in New York City? Journal of Consumer Policy. 23:127-52, 2000.

HENDERSON, B. D. The Logic of Business Strategy. Cambridge: Mass, 1984.

HODGSON, J. Thinking on your feet in negotiations. Londres: Pitman, 1996.

HOGARTH-SCOTT. Retailer-supplier partnerships: hostages to fortune or the way forward for the millennium? British Food Journal, v.101, n.9, 1999.

IACOBUCCI, Dawn (org). Os Desafios do Marketing. São Paulo: Futura, 2001.

JAIN, Subhash C. Marketing Planning \& Strategy. $6^{\text {th }}$. ed. Cincinnati, Ohio: SouthWestern College Publishing - Thompson Learning, 2000.

JÓIA, Luiz A. Geração de modelos teóricos a partir de estudos de casos múltiplos: da teoria à prática. In: VIEIRA, Marcelo M. F; ZOUAIN, Deborah M (Org). Pesquisa Qualitativa em Administração. São Paulo: FGV, 2004.

KAUFMAN, Phillip R.; MACDONALD, James M.; LUTZ, Steven M.; SMALLWOOD, David M. Do the poor pay more for food? Item selection and price differences affect lowincome household food costs. Agricultural Economics Report. (759) Washington, DC: Economic Research Service, U.S. Department of Agriculture, 1997. 
KIM, Youn-Kyung; HAN, Seunghae. Perceived images of retail stores: comparison among three ethnic consumer groups. Journal of Family and Consumer Behavior. V.92 (3), p 58$61,2000$.

KOTLER, Philip.; ARMSTRONG, Gary. Princípios de Marketing. 7. ed. Rio de Janeiro: Prentice-Hall do Brasil, 1998.

KOTLER, Philip; KELLER, Kevin Lane. Administração de Marketing. 12a . Nova Iorque: Prentice Hall, 2005.

KUMAR, Nirmalya. The revolution in retailing: from market driven to market driving. Long Range Planning, v.30, n.6, p.830-835, 1997.

KUNKEL, J. H.; BERRY, L. L. A behavioral concept of retail images. Journal of Marketing. V. 32 (4), p 21-27, 1968.

LAMBIN, Jean-Jacques. Market-Driven Management: Strategic \& Operational Marketing. New York: Palgrave Publishers, 2000a.

Marketing Estratégico. 4a. ed. Lisboa: McGraw-Hill, 2000 b.

LAZZARINI, Sérgio. G. Estudos de caso para fins de pesquisa: aplicabilidade e aplicações do método. In: FARINA Elizabeth M. M. Q. (Coord). Estudo de Caso em Agribusiness. São Paulo: Pioneira, 1997. cap. 1, p. 9-23.

LEPSCH, Sérgio Luiz. Precificação em Supermercado: um estudo exploratório junto a vinte empresas brasileiras. Dissertação apresentada ao Departamento de Administração da Faculdade de Economia, Administração e Contabilidade da Universidade de São Paulo, para obtenção do título de Mestre em Administração, São Paulo, 1996.

LEVY, Michael; WEITZ, Barton A. Administração de Varejo. São Paulo: Atlas, 2000.

LIMA, C.R. Manual Prático de controle de qualidade em supermercados. São Paulo: Livraria Varela, 2001.

LINDQUIST, J. D. Meaning of image: a survey of empirical and hypothetical evidence. Journal of Retailing. V. 50 (4), p. 29-38, 1974. 
LOPES, Alexandre B; REIS, Ana Carla F; ABUKAWA, André O. Aplicação dos 4 P's na Indústria Papeleira: O Caso Brasileiro. Caderno de Pesquisa em Administração. São Paulo, V 1, No. 2, $1^{\text {o. Sem} / 1996 . ~}$

LOVELOCK, Christopher H. Services Marketing. $3^{\text {rd }}$. ed. New Jersey: Prentice-Hall, 1996. LÜDKE, M.; ANDRÉ, Marli E. D. A. Pesquisa em Educação: abordagens qualitativas. São Paulo: EPU, 1986.

LUKIANOCENKO, M. $3^{\circ}$ Ranking das centrais de compras. Revista SuperHiper, ano 29, n.337, p. 8-17, nov. 2003.

LUKIANOCENKO, M. Setor mostra sua força em ano difícil. Revista SuperHiper, ano 30, n.342, p.14-32, maio 2004.

MACDONALD, James M.; NELSON, Paul E. Do the poor still pay more? Food price variations in large metropolitan areas. Journal of Urban Economics. 30:344-59, 1991.

MANKIW, N. G. Introdução à Economia: princípios de micro e macroeconomia. Rio de Janeiro: Campus, 1999.

MARTINS, G.A. \& LINTZ A. Guia: Elaboração de Monografias e Trabalhos de Conclusão de Curso. São Paulo, 1999.

MASON, J. Barry; MAYER, Morris L.; EZELL, Hazel F. Retailing. 3 ed. Texas: Business Publication, Inc., 1988.

MATTAR, Fauze N. Pesquisa de Marketing. v1. São Paulo: Atlas, 1999.

MAZZON, José Afonso, GUAGLIARDI, José Augusto, FONSECA, Jairo S. Marketing: Aplicações de Métodos Quantitativos. São Paulo: Editora Atlas, 1983.

MCCARTHY, E. Jerome. Essentials of Marketing. Homewood, Illinois, Richard D. Irwin, revised edition, 1982.

MCCARTHY, E. Jerome; PERREAULT JR, William. D. Marketing essencial: uma abordagem gerencial e global. São Paulo: Atlas, 1997.

MCGOLDRICK, Peter J. Retail Marketing. Londres, McGraw-Hill, 1990. 
MCGUIGAN, James R. et alii. Managerial ecomnomics: applications, strategy and tactics. 8 ed., South Western,1999.

MCMILlAN, John; MORGAN, Peter B. Price Dispersion, Price Flexibility and Repeated Purchasing. Canadian Journal of Economics. 21, 883-902, 1988.

MORGENSTEIN, M; STROGIN, H. Modern Retailing: management principles and practices. 3 ed. Englewood Cliffs, New Jersey, Prentice-Hall, 1992.

MONROE, Kent B. Pricing: Making Profitable Decisions. 5th ed. New York: McGraw-Hill, 1990.

NAGLE, Thomas T.; HOLDEN, Reed K. Estratégia e Táticas de Preços.: Um Guia para Decisões Lucrativas. $3^{\text {a }}$. ed. São Paulo: Pearson - Prentice Hall, 2003.

NEVES, Marcos F. Um modelo para planejamento de canais de distribuição no setor de alimentos. 1999. Tese (Doutorado em Administração) - Faculdade de Economia, Administração e Ciências Contábeis, Universidade de São Paulo, São Paulo.

Planejamento e Gestão Estratégica de Marketing. São Paulo: Atlas, 2005.

NICOL, Robert. Microeconomia. São Paulo, Atlas, 1985.

NIERENBERG. G.I. The art of negotiating. New York: Simon \& Schuster, 1981.

PALMER, Adrian. Principles of Marketing. Oxford: Oxford University Press, 2000.

PARENTE, Juracy G. Varejo no Brasil: gestão e estratégia. São Paulo: Atlas, 2000.

POIRIER, Charles C.; REITER, Stephen E. Supply Chain Optimization. San Francisco: Berret-Koehler Publishers, 1996.

PORTER, Michael E. Vantagem Competitiva: criando valor e sustentando um desempenho superior. Rio de Janeiro: Campos, 1992.

Estratégia Competitiva: Técnicas para Análise de Indústrias e da Concorrência. Rio de Janeiro: Campus, 1980. 
PYINDICK, R S; RUBINFELD, DL. Microeconomia. 5ª ed. São Paulo: Prentice Hall, 2002.

REINGANUM, Jennifer. A Simple Model of equilibrium Price Dispersion. Journal of Political Economy. 87, 851-858, 1979.

RICHARDSON, Richard J. e colaboradores. Pesquisa social: métodos e técnicas. São Paulo: Atlas, 1999.

ROB, Rafael. Equilibrium Price Distributions. Review of Economics Studies. 52, 487-504, 1985.

ROCHA, Angela da; CHRISTENSEN, Carl. Marketing: teoria e prática. 2.ed. São Paulo: Atlas, 1999.

ROCHA, Angela. da; CERETTA, P.S. Pesquisa qualitativa: um desafio à ciência social. In: $22^{\circ}$ Encontro Nacional de Pós-Graduação em Administração -ENANPAD. 1998. Foz do Iguaçu. Anais... Foz do Iguaçu, PR, 1998. CD-ROM.

ROSENBLOOM, Bert. Marketing Channel: a Management View. $6^{\text {th }}$. Edition. New York: The Dryden Press, 1999.

ROSSETTI, José Paschoal. Introdução à economia. 18 ed. São Paulo: Atlas, 2000.

SARDINHA, José Carlos. Formação de preço: a arte do negócio. 1 ed. São Paulo: Makron Books, 1995.

SATO, G.S.; BESSA JR., A.A. The brazilian food retail market: concentration by mergers and acquisitions. In: World Congress of Rural Sociology e XXXVIII Brazilian Congress of Rural Economy and Sociology. 2000. Rio de Janeiro. Anais.. Rio de Janeiro -RJ, 30 jul. -05 ago. 2000.

SCHULTZ, Don F.; BARNES, Beth E. Campanhas Estratégicas de Comunicação de Marcas. Rio de Janeiro: Qualitymark, 2001.

SENHORAS, E.M. O varejo supermercadista sob perspectiva. Revista Eletrônica de Administração, UFRGS, Porto Alegre, ed. 33, n. 3, v. 9, jun. 2003.

SELLTIZ, Claire; JAHODA, Marie; DEUTSCH, Morton; COOK, Stuart. Métodos de pesquisa nas relações sociais. São Paulo: E.P.U./ Edusp, 1975. 
SESSO FILHO, U.A. O setor supermercadista no Brasil nos anos 1990. 2003. 216p. Tese (doutorado em Ciências, área de concentração Economia Aplicada)-Escola Superior de Agricultura Luís de Queiroz, Universidade de São Paulo, Piracicaba, 2003.

SHETH, Jagdish N.; MITTAL, Banwari; NEWMAN, Bruce I. Comportamento do Cliente: Indo Além do Comportamento do Consumidor. São Paulo, Atlas, 2001.

SILVEIRA, José Augusto G.; LEPSCH, Sérgio L. Alterações recentes na economia do setor supermercadista brasileiro. Revista de Administração da USP. São Paulo, v.32, n.2, p.5-13, abr./jun. 1997.

SIMONSEN, Mário H. Teoria microeconômica: teoria do consumidor, teoria da produção. Rio de Janeiro: FGV, 1973.

SPROTT, David E.; MANNING, Kenneth C.; MIYAZAKI, Anthony. Grocery price settings quantity surcharges. Journal of Marketing. 67. p. 34-46, july, 2003.

STAKE, Robert E. The art of case study research. Thousand Oaks: Sage, 1999.

STANTON, Willian. J; WALKER, Bruce. J; ETZEL, Michael. J. Marketing. São Paulo: Makron Books, 2001.

STERN, Louis W.; EL-ANSARY, Adel I.; COUGHLAN, Anne T. Marketing Channels. New York: Prentice Hall, 5 ed., 1996.

STRAUSS, A.; CORBIN, J. Basics of qualitative research: grounded theory procedures and techniques. USA: Sage Publications, 1990.

SUBRAHMANYAN, Saroja. Using quantitative models for setting retail prices. Journal of Product and Brand Management. Santa Bárbara, 2000.

TELLIS, Gerard J. Beyond the many faces of price: an integration of pricing strategies. Journal of Marketing. 50. p. 146 - 160, 1986.

. Tackling tje retailer decision make: wich brands to discount, how much, when and why?. Marketing Science. 14. no. 3. part 2, p 271-299, 1995. 
URDAN, Flávio T.; URDAN, André T. Gestão do Composto de Marketing. São Paulo: Atlas, 2006.

TOLEDO, Geraldo L; PROENÇA, Maria Cristina A; MELLO JR, Sergio B. B. Estratégia Competitiva e Política de Preços: um estudo de casos na indústria de varejo alimentício. In: VII Seminário em Administração - SEMEAD. 2003. São Paulo. Anais... São Paulo, SP, 2003. CD-ROM.

. Justifying profitable prices. Journal of Product and Brand Management. 10, no. 3. p 141-157, 2001.

TREVIÑOS, Augusto N. S. Introdução à pesquisa em ciências sociais. São Paulo: Atlas, 1987.

TULL, D. S; HAWKINS, D. I. Marketing Research, Meaning, Measurement and Method. Macmillan Publishing Co., Inc., London, 1976.

VANCE, Patricia S.; ANGELO, Claudio F. Fixação de preços em lojas de conveniência: estudo da influência da concentração varejista. Revista de Administração. São Paulo, v.38, $\mathrm{n}^{\mathrm{o}}$ 1, p. 25-36, janeiro-março, 2003.

VANHUELE, Marc; DREZE, Xavier. Measuring the price knowledge shoppers bring to the store. Journal of Marketing. 66: 4; p. 72, 2002.

VERGARA, Sylvia C. Projetos e relatórios em pesquisas de administração. São Paulo: Atlas, 1998.

VIEIRA, Marcelo M. F. Por uma boa pesquisa (qualitativa) em administração. In: VIEIRA, Marcelo M. F.; ZOUAIN, Débora M. Pesquisa qualitativa em administração. São Paulo: FGV, 2004.

YIN, Robert K. Case study research: design and methods. 2nd USA: Sage Publications, 1994.

ZICKER, Alberto. Modelo para formação de preços a partir do valor percebido pelo mercado. 2002. Dissertação (Mestrado em Engenharia) - Universidade Federal de Santa Catarina, Florianópolis. 